\title{
PROTECTING THE RIGHT TO EFFECTIVE ASSISTANCE OF CAPITAL POSTCONVICTION COUNSEL: THE SCOPE OF THE CONSTITUTIONAL OBLIGATION TO MONITOR COUNSEL PERFORMANCE
}

\author{
Celestine Richards McConville*
}

\section{INTRODUCTION}

It is no secret that capital cases in the United States are far from error free. According to a recent study, the two most common errors in capital cases are "egregiously incompetent defense lawyering" and "prosecutorial suppression of evidence that the defendant is innocent or does not deserve the death penalty." Other errors include inaccurate eyewitness testimony, perjured testimony, and false confessions, just to name a few. ${ }^{2}$ And, since 1973, no fewer than 117 capital inmates have been released from death row because errors such as these camouflaged their innocence. ${ }^{3}$

\footnotetext{
* Associate Professor of Law, Chapman University School of Law. B.A. 1988, Boston University; J.D. 1991, Georgetown University Law Center. Thanks to Crystal Hodgson for excellent research assistance, to Robin Wellford Slocum and Scott W. Howe for helpful comments on a prior draft, and to the participants of the faculty workshop at Chapman University School of Law for useful feedback on the ideas presented in this Article. Thanks also to the Chapman University School of Law for supporting this Article with a research grant. Special thanks to Thomas S. McConville for unwavering support. As always, any errors are my own.

1. James S. Liebman et al., A Broken System: Error Rates in Capital Cases, 1973-1995, at 6, available at http://justice.policy.net/jpreport/index.html (last visited Nov. 29, 2004).

2. For a thorough and interesting account of the different errors in capital cases, see BARRY Scheck et al., Actual Innocence: Five Days to Execution and Other Dispatches from the Wrongly Convicted (2000). See also American Bar Association Guidelines for the Appointment and Performance of Defense Counsel in Death Penalty Cases, 31 Hofstra L. Rev. 913, 1017 (2003) [hereinafter 2003 ABA Guidelines] (listing errors that "have contributed to wrongful convictions in both capital and non-capital cases"); Death Penalty Information Center, Cases of Innocence 1973-Present, at http://www.deathpenaltyinfo.org/article.php?scid=6\&did=109 (last visited Nov. 29, 2004) (describing cases of wrongful convictions in capital cases, and reasons for such convictions).

3. Death Penalty Information Center, Innocence and the Death Penalty, at http://www.death penaltyinfo.org/article.php?did $=412 \&$ scid $=6$ (last visited Nov. 29, 2004). The Death Penalty Information Center compiles its list of innocent inmates according to the following criteria: Defendants "had been convicted and sentenced to death, and subsequently either a) their conviction was overturned and they were acquitted at a re-trial, or all charges were dropped; orb) they were given an absolute pardon by the governor based on new evidence of innocence." Death Penalty Information Center, supra note 2. These criteria were applied in all but five of the 115 exoneration cases. $I d$.
} 
While the direct review process catches some of these errors, ${ }^{4}$ it does not catch them all. Errors are also discovered after direct review, during state and federal postconviction review (also called "collateral review")..$^{5}$ Indeed, according to this same recent study, courts grant ten percent of state postconviction petitions and forty percent of first federal habeas ${ }^{6}$ petitions, ${ }^{7}$ proving that proper use of state and federal postconviction remedies literally saves the lives of innocent ${ }^{8}$ capital inmates. ${ }^{9}$ In the words of the Texas Defender Service, postconviction review "is, in effect, the 'quality control' process in the administration of capital punishment. It is supposed to act as a safety net, allowing the system to catch its mistakes."10

Postconviction review cannot serve its "quality control" 11 or "safety net" 12 function, however, without the assistance of competent postconviction

4. Liebman et al., supra note 1, at 35-39 (revealing a forty-one percent reversal rate of capital cases on state direct review over a twenty-three year period).

5. As the Texas Defender Service observed in its recent study of the performance of capital postconviction counsel in Texas:

Most exonerations [of death row inmates through August 2002] have come during habeas corpus proceedings, when lawyers uncovered evidence of innocence, prosecutorial misconduct, ineffective representation, mistaken identifications, perjured testimony by state witnesses, or unreliable scientific evidence and presented it to the courts.

Texas Defender Service, Lethal Indifference: The Fatal Combination of Incompetent Attorneys and Unaccountable Courts in Texas Death Penalty Appeals 4-5, at http://www.texasdefender.org/ publications.htm (last visited Nov. 29, 2004) [hereinafter Texas Defender Service].

6. This Article uses the terms "habeas" and "postconviction" interchangeably.

7. Liebman et al., supra note 1, at 2, 6, 57 tbl. 5 .

8. The term "innocent" refers to inmates who are either actually innocent of the underlying crime or "actually innocent of the death penalty." Sawyer v. Whitley, 505 U.S. 333, 347 (1992). A capital inmate is "actually innocent of the death penalty" if she is legally ineligible for the death penalty under applicable state law. $I d$.

9. See, e.g., Standards for the Appointment and Performance of Counsel in Death Penalty Cases, National Legal Aid and Defender Ass'N § 11.9.3 (1988) [hereinafter NLADADeath Penalty Standards] (asserting that the high error rate on capital postconviction review "indicates that substantial error is not being prevented or cured at earlier stages"); 2003 ABA Guidelines, supra note 2, at Guideline 1.1, at 932 (noting that postconviction procedures "are especially important in capital cases"); Andrew Hammel, Effective Performance Guarantees for Capital State Post-Conviction Counsel: Cutting the Gordian Knot, 5 J. APP. PrAC. \& Process 347, 348 (2003) (asserting that "post-conviction proceedings are, after trial, perhaps the most common and effective means of forestalling substantive injustice in capital cases"); Texas Defender Service, supra note 5, at ix-x, xiv, 1-2 (discussing the importance of postconviction relief in protecting innocent defendants); $i d$. at xi (noting that proper use of state habeas proceedings is integral to obtaining relief during federal habeas stages).

10. Texas Defender Service, supra note 5, at 2. See also Christopher Flood, Closing the Circle: Case v. Nebraska and the Future of Habeas Reform, 27 N.Y.U. Rev. L. \& Soc. Change 633, 643-45 (2001-2002) (discussing the importance of postconviction review).

11. Texas Defender Service, supra note 5, at 2.

12. $I d$. 
counsel. ${ }^{13}$ Postconviction proceedings are exceedingly complex,${ }^{14}$ and few, if any, capital inmates have the knowledge, training or resources to successfully navigate these proceedings pro se. ${ }^{15}$ Counsel must not only possess sufficient substantive and procedural knowledge, ${ }^{16}$ but must also investigate, discover, and properly raise all viable claims of constitutional error, first in state court and then in federal court. ${ }^{17}$ Failure to do so can be catastrophic, for claims not properly presented and preserved in state court generally will not be reviewed on their merits in federal court. ${ }^{18}$ The same is

13. See, e.g., 2003 ABA Guidelines, supra note 2, at Guideline 1.1, at 931 (concluding that the "courts must appoint appropriately trained and experienced lawyers" in order "[f]or post-judgment review to succeed as a safeguard against injustice"); $i d$. at 932 (asserting that lawyers must provide "[q]uality representation in both state and federal court ... if legally flawed convictions and sentences are to be corrected"); Ad Hoc Comm. on Fed. Habeas Corpus in Capital Cases, Judicial Conf. of the U.S., Report on Feder al Habeas Corpus in Capital Cases, reprinted in 45 Crim. L. Rep. (BNA) 3239, 3240 (recognizing the "pressing need for qualified counsel to represent inmates in collateral review"); Celestine Richards McConville, The Right to Effective Assistance of Capital Postconviction Counsel: Constitutional Implications of Statutory Grants of Capital Counsel, 2003 WIS. L. REv. 31, 84-87 (2003) (discussing the necessity of competent capital postconviction counsel); Texas Defender Service, supra note 5, at 2 (asserting that the state postconviction process "should provide all death row inmates with lawyers who properly investigate the cases and courts that allow them an opportunity to present evidence of innocence or other fundamental flaws that render the proceedings unreliable").

14. In the words of Professor Michael Mello: "If the Court's capital jurisprudence is opaque, its habeas corpus jurisprudence is Byzantine." Michael Mello, Facing Death Alone: The Post-Conviction Attorney Crisis on Death Row, 37 Am. U. L. Rev. 513, 534 (1988); see also 2003 ABA Guidelines, supra note 2, at Guideline 10.15.1, at 1085 ("The field is increasingly complex and ever changing.").

15. See Ad Hoc Comm. on Fed. Habeas Corpus in Capital Cases, supra note 13, at 3239, 3240 ("Capital inmates almost uniformly are indigent, and often illiterate or uneducated. ... Prisoners acting pro se rarely present promptly or properly exhaust their constitutional challenges in the state forum."); Hammel, supra note 9, at 395 ("No death-row inmate will ever be set free from his prison cell to perform the thorough, independent investigation of his case that is a fundamental component of competent habeas representation.") (internal quotation omitted).

16. This is not as simple as it might sound. As the ABA explains:

As state and federal collateral proceedings become ever-more intertwined, counsel representing a capital client in state collateral proceedings must become intimately familiar with federal habeas corpus procedures.... [F]or example, although the [Antiterrorism and Effective Death Penalty Act] deals strictly with cases being litigated in federal court, its statute of limitations provision creates a de facto statute of limitations for filing a collateral review petition in state court. Some state collateral counsel have failed to understand the AEDPA's implications, and unwittingly forfeited their client's right to federal habeas corpus review.

2003 ABA Guidelines, supra note 2, at Guideline 10.15.1, at 1085.

17. See 28 U.S.C. $\S \S 2254$ (b), 2264 (2000); Coleman v. Thompson, 501 U.S. 722,731 (1991); Wainwright v. Sykes, 433 U.S. 72, 80-81 (1977); see also, e.g., McConville, supra note 13, at 80-82 (explaining the process for state and federal postconviction review).

18. A claim that has been procedurally defaulted in state court will not be entertained in federal habeas corpus proceedings unless the federal habeas petitioner "demonstrate[s] cause for the default and actual prejudice as a result of the alleged violation of federal law, or demonstrate[s] that failure to consider the claims will result in a fundamental miscarriage of justice." Coleman, 501 U.S. at 750; see also Sykes, 
true of claims raised improperly at the federal level. ${ }^{19}$ Accordingly, incompetent performance by capital postconviction counsel in either state or federal court not only deprives the capital inmate of the opportunity to obtain review on the merits, but, more importantly, it deprives the capital inmate of the possibility of obtaining relief. ${ }^{20}$ With a forty percent reversal rate on federal habeas, that is a significant deprivation. ${ }^{21}$

For their part, the states and the federal government seem to appreciate the need to provide postconviction counsel. Although the Supreme Court has held that the states have no constitutional obligation to provide postconviction counsel, ${ }^{22}$ at least thirty-two of the thirty-eight death penalty states provide a mandatory right to capital postconviction counsel. ${ }^{23}$ And, while the Supreme Court has not specifically addressed the federal government's constitutional obligation to provide counsel during federal habeas proceedings, ${ }^{24}$ the federal

433 U.S. at 87.

19. The passage of the Antiterrorism and Effective Death Penalty Act of 1996 ("AEDPA") made the filing of timely and proper habeas petitions much more difficult. Antiterrorism and Effective Death Penalty Act of 1996, Pub. L. No. 104-132, 110 Stat. 1214 (codified as amended in scattered sections of U.S.C.). Among other things, the AEDPA established a one-year deadline for filing the first (and likely only) federal habeas petition, which begins running at the "the conclusion of direct review or the expiration of time for seeking such review." 28 U.S.C. $\S 2244(d)(1)(A)$. It also prohibited "second or successive" petitions, unless the petitioner satisfies one of two very narrow exceptions. Id. § 2244(b)(2). For a thorough review of the AEDPA and its impact on the availability of federal habeas relief, see 1 RANDY Hertz \& James S. Liebman, Federal Habeas Corpus Practice and Procedure $\S \S 3.1-3.5$ (4th ed. 2001).

20. In the words of Professors Randall Coyne and Lyn Entzeroth: "In the event post-conviction attorneys render inadequate or ineffective assistance, causing irreparable harm to their clients' cases, there is no remedy." Randall Coyne \& Lyn Entzeroth, Report Regarding the Implementation of the American Bar Association's Recommendations and Resolutions Concerning the Death Penalty and Calling for a Moratorium on Executions, 4 Geo. J. On Fighting Poverty 3, 21 (1996).

21. Improving the quality and performance of trial and appellate counsel will not reduce the need for competent postconviction counsel. As the ABA explains:

Ensuring high quality legal representation in capital trials ... does not diminish the need for equally effective representation on appeal, in state and federal post-conviction proceedings, and in applications for executive clemency. Because each of those proceedings has a unique role to play in the capital process, because both legal and social norms commonly evolve over the course of a case, and because of the general tendency of evidence of innocence to emerge only at a relatively late stage in capital proceedings, jurisdictions that retain capital punishment must provide [competent] representation ... at all stages of the case.

2003 ABA Guidelines, supra note 2, at Guideline 1.1, at 930-31 (internal quotations omitted).

22. See Murray v. Giarratano, 492 U.S. 1, 3-4 (1989); Pennsylvania v. Finley, 481 U.S. 551, 554-56 (1987).

23. McConville, supra note 13, at 64 (listing states). Four death penalty states provide a discretionary right to capital postconviction counsel, and two death penalty states provideno right to capital postconviction counsel. Id. (listing states).

24. The Court's decisions on the subject of a constitutional right to postconviction counsel have 
government voluntarily provides mandatory capital postconviction counsel as well. ${ }^{25}$ The problem, however, is that in Wainwright $v$. Torna,${ }^{26}$ the Supreme Court ruled that the constitutional right to effective assistance of counsel does not extend to statutory grants of counsel. And, because only constitutionally ineffective counsel is sufficient to excuse a procedural default, ${ }^{27}$ capital postconviction petitioners are forced to bear the burden of counsel's errors.

Elsewhere this author has challenged the Court's conclusion in Torna, arguing that the government's decision to voluntarily provide postconviction counsel triggers a due-process-based obligation to provide effective assistance of counsel. ${ }^{28}$ Specifically, this author argued that the Due Process Clause contains a meaningfulness requirement, "which in essence means that when the government creates a right designed to protect or enhance the reliability of the criminal trial or the individual liberty of the criminal defendant, the ... right must be meaningful. ${ }^{29}$ And the right to postconviction counsel is meaningful only if it contains an effectiveness guarantee, which, in the postconviction context, means that the lawyer appointed to represent the capital inmate must meet rigorous competency standards and must be subjected to a "during-performance review" designed to uncover problems with her performance. ${ }^{30}$ While these two requirements will not guarantee competent performance in every case, they surely will increase the likelihood of competent performance, and thereby reduce the number of instances in which capital petitioners must bear the burden of counsel's incompetence.

This Article undertakes an in-depth examination of the scope and substance of the constitutionally-mandated during-performance review (which can also be called the "monitoring requirement"). Such an examination is important because, unlike the concept of competency standards, about which 
there already exists a good amount of written work, ${ }^{31}$ the concept of monitoring capital postconviction counsel is less well-developed. For example, while Congress has (impliedly) authorized postconviction monitoring by permitting courts to appoint new state or federal capital postconviction counsel upon a finding of "ineffectiveness or incompetence of counsel, ${ }^{, 32}$ it does not explain precisely what conduct would constitute ineffectiveness or incompetence, or how the courts ought to go about monitoring for such conduct. ${ }^{33}$ Nor can we glean much from the practical experience of the states, as they can hardly be described as having jumped on a "monitoring bandwagon." It appears that only one state-Florida - expressly requires monitoring of capital postconviction

31. This work includes not only scholarly evaluation of the need for such standards, but also wellcrafted proposed standards. See, e.g., Vivian Berger, Justice Delayed or Justice Denied? - A Comment on Recent Proposals to Reform Death Penalty Habeas Corpus, 90 Colum. L. Rev. 1665, 1687-1690 (1990) (discussing the need for competency standards for capital counsel); Ira P. Robbins, Toward a More Just and Effective System of Review in State Death Penalty Cases, 40 Am. U. L. Rev. 1, 14-19 (1990) [hereinafter ABA Recommendations] (same); id. at 258-60 (proposing detailed competency standards for capital postconviction counsel); 2003 ABA Guidelines, supra note 2, at Guideline 5.1, at 961 (listing factors an appointing agency should consider when formulating competency standards).

Professor Donald A. Dripps proposes a solution to counsel incompetence that builds upon (but does not completely embrace) the idea of competency standards. He argues for "an ex ante inquiry into whether the defense is institutionally equipped to litigate as effectively as the prosecution." Donald A. Dripps, Ineffective Assistance of Counsel: The Case for an Ex Ante Parity Standard, 88 J. CRIM. L. \& CRIMINOLOGY 242, 243 (1997). This "parity standard" focuses on whether "the litigation capability of the adversaries, independent of the merits of their respective cases, is more-or-less evenly matched." Id. at 293. As he explains: "Courts could make this determination either in collateral civil proceedings to test the effectiveness of the indigent defense system, or in individual criminal cases upon a pretrial motion claiming that effective assistance cannot be rendered in the instant case because of the indigent's defense system's deficiencies." Id. at 243. Instead of relying on "minimum qualifications" to achieve this parity, Professor Dripps argues that courts should examine the following factors:

(a) whether defense counsel's credentials and experience would enable defense counsel to compete for a post in the prosecutor's office with responsibilities for prosecuting charges similar in severity and complexity to those against the accused; (b) whether defense counsel is compensated at a level comparable to the compensation paid to a lawyer of comparable seniority in the prosecution's office; and (c) whether defense counsel's current caseload permits defense counsel to defend the case as vigorously as it will be prosecuted, given the investigative resources and support staff available.

Id. at 293-94.

32. 28 U.S.C. $\$ 2261$ (e) (authorizing "the appointment of different counsel, on the court's own motion or at the request of the prisoner, at any phase of State or Federal post-conviction proceedings on the basis of the ineffectiveness or incompetence of counsel in such proceedings").

33. We likely cannot expect much guidance from the courts on this score, as the section that (impliedly) authorizes such monitoring is contained in Chapter 154, a chapter of Title 28 applicable only in those states that satisfy the relevant opt-in requirements. 28 U.S.C. $\S 2261$. While Arizona has successfully met those requirements, see Spears v. Stewart, 283 F.3d 992 (9th Cir. 2002), numerous other states have failed to do so. See McConville, supra note 13, at 62. 
counsel. ${ }^{34}$ Finally, although the American Bar Association ("ABA") has endorsed monitoring as a way of ensuring the competence of capital counsel (including postconviction counsel), ${ }^{35}$ and has published recommendations regarding the general duty to monitor all capital counsel for "high quality legal representation," ${ }^{36}$ its recommendations nevertheless are incomplete. For example, while the ABA directs the monitoring entity to establish procedures

34. Fla. StAT. ANN. § 27.711(12) (West 2003) (stating a court must "monitor the performance of assigned counsel to ensure that the capital defendant is receiving quality representation"). California appears to authorize, if not implicitly require, monitoring of capital postconviction counsel. For example, it requires capital postconviction counsel to file a "confidential status report [with the court] . . . every 60 days." Press Release, Judicial Council of California, Supreme Court Adopts New Procedures on Death Penalty Cases, at Addendum I.B (Aug. 22, 2001), available at http://www.courtinfo.ca.gov/news releases/NR54-01.htm (announcing the adoption of new and mandatory California Supreme Court procedures regarding capital cases, including the requirement of regular, confidential status reports). The logical purpose of such reports, of course, would appear to be to allow the court to gauge the adequacy of counsel's performance. Moreover, the California Habeas Corpus Resource Center, established by the state legislature, is authorized "[t]o provide . . case progress monitoring as needed." CAL. Gov. CodE $\S 68661(\mathrm{j})$. While this provision neither defines the term "case progress monitoring," nor expressly requires monitoring, it does at least suggest that monitoring might well take place. For a list of other states that authorize monitoring of capital counsel, see McConville, supra note 13, at 66-67 \& nn.197-201.

35. See 2003 ABA Guidelines, supra note 2, at Guideline 7.1, at 970 (recommending that an entity independent of the courts "should monitor the performance of all defense counsel to ensure that the client is receiving high quality legal representation"); ABA Standing Comm. on Legal Aid AND INDigent Defendants, The Ten Principles of a Public Defense Delivery System, Principle 10 (2002) (recommending "supervis[ion] and systematic[] review[] [of defense counsel] for quality and efficiency according to nationally and locally adopted standards"), available at $\mathrm{http}: / / \mathrm{www}$.abanet.org/legalservices/ sclaid/defender/home.html (last visited Dec. 1, 2004).

The National Legal Aid and Defender Organization ("NLADA") also has published standards endorsing the monitoring of capital counsel. See NLADA Death Penalty Standards, supra note 9, at Standard 7.1, at 23 (recommending "monitor[ing] . . . to ensure that the client is receiving quality representation"); see also NLADA, Standards for the Administration of Assigned Counsel Systems, Standard 4.4.2 (1989) (recommending monitoring of counsel in all criminal cases where private counsel is appointed), available at http://www.nlada.org/Defender/Defender_Standards/Defender Standards_NLADA (last visited Dec. 1, 2004). The NLADA's Death Penalty StAndards, which cover all aspects of the appointment and performance of capital counsel, were submitted to the ABA for review. See ABA, American Bar Association Guidelines for the Appointment and Performance of Counsel in Death Penalty Cases (Feb. 1989), available at http://www.abanet.org/legalservices/ downloads/sclaid/dpguide.wpd at 2 [hereinafter 1989 ABA GuIDELINES]. In 1989, the ABA adopted the standards and published them in the form of the 1989 ABA Guidelines. Id. Although the ABA made some revisions to the NLADA's version, see id., it left the monitoring provisions virtually untouched. Compare id. at Guideline 7.1 with NLADA, DeAth Penalty STANDARDs, supra note 9, at Standard 7.1. The ABA updated the 1989 ABA GuIDELINES in 2003, making several changes to the monitoring provisions. 2003 ABA Guidelines, supra note 2, Introduction, at 916; id. at Guideline 7.1, at 971.

36. 2003 ABA Guidelines, supra note 2, at Guideline 7.1, at 970. The Texas Defender Service also appears to endorse monitoring. See Texas Defender Service, supra note 5, at 64 (recommending "[e]stablish[ment] [of] meaningful statewide standards for capital counsel, including mandatory peer review"). 
for a "systematic review" of counsel's performance, it fails to explain (or suggest) what those procedures should be. ${ }^{37}$ Moreover, although the ABA authorizes the monitoring entity to "take appropriate action"- a seemingly broad mandate - should it find that counsel is not "providing high quality legal representation," ${ }^{38}$ it neglects to define the precise range of remedies that would be appropriate in a given case. ${ }^{39}$

To be sure, scholarly observers have long suggested monitoring as a way of ensuring attorney competence, but those suggestions have focused on monitoring criminal trial counsel, not capital postconviction counsel. ${ }^{40}$ Because of the difference in procedural context and the specialized nature of death penalty jurisprudence, it is necessary to separately examine the scope and substance of the government's monitoring obligation during postconviction review (though undoubtedly the suggestions regarding monitoring in the trial context will be relevant to this examination).

This Article explores the constitutional requirements for structuring a system of postconviction monitoring. Perhaps not surprisingly, this exploration implicates the due-process-based meaningfulness requirement, for just as the government must make the right to postconviction counsel

37. Id. at Guideline 7.1, at 973 . The monitoring entity must use the performance standards contained with the 2003 ABA Guidelines when monitoring counsel's performance. Id. at Guideline 10.1, at 989 .

38. Id. at Guideline 7.1, at 970.

39. The ABA expressly authorizes removal from the roster of eligible attorneys. See id. at Guideline 7.1, at 970. And, while not entirely clear, it also appears to authorize removal from the particular case under review. See id. at 973-74 (noting that petitioners "should have the right to continue satisfactory relationships with lawyers in whom they have reposed their confidence and trust," but also directing the monitoring entity to "intervene" where counsel fails to "provid[e] high quality legal representation"). The ABA is otherwise silent on what actions the monitoring entity should take to solve problems with counsel's performance.

40. See Richard Klein, The Relationship of the Court and Defense Counsel: The Impact on Competent Representation and Proposals for Reform, 29 B.C.L. REv. 531, 564-84 (1988) (recommending trial court monitoring of criminal defense attorneys); Barbara R. Levine, Preventing Defense Counsel Error-An Analysis of Some Ineffective Assistance of Counsel Claims and Their Implications for Professional Regulation, 15 U. ToL. L. Rev. 1275, 1426-35 (1984)(same); William W. Schwarzer, Dealing with Incompetent Counsel-The Trial Judge's Role, 93 HARV. L. REV. 633 (1980) (recommending that the trial court monitor trial counsel); Peter W. Tague, The Attempt To Improve Criminal Defense Representation, 15 AM. CRIM. L. REv. 109, 161-65 (1977) (recommending trial court monitoring of criminal defense attorneys). But see Gary Goodpaster, The Trial for Life: Effective Assistance of Counsel in Death Penalty Cases, 58 N.Y.U. L. REv. 299, 357 n.214, 359-60 (arguing that the "constraints on the judicial role, evidentiary privileges limiting the ability of a judge to inquire into defense counsel's case, incompatibility with good advocacy, and the possible self-serving nature of counsel's declarations make [judicial monitoring] an inadequate and dangerous substitute for postconviction review of attorney competence"). 
meaningful by monitoring counsel's performance, it must also ensure that the process of monitoring is itself meaningful. Accordingly, the Article begins in Part I by explaining the meaningfulness requirement, including how the requirements for meaningfulness must be implemented. Part II then applies the meaningfulness requirement in the context of monitoring capital postconviction counsel, explaining what a meaningful system of monitoring ought to look like.

Beginning with the question of who should perform the monitoring function, Part II explains that, while on balance independent entities might be a better choice, the courts could perform the monitoring function in a manner that would satisfy the meaningfulness requirement, provided the courts are not overburdened and provided there is no evidence in the particular jurisdiction of systematic and routine disregard for the constitutional rights of capital inmates. Part II then argues that, when evaluating counsel's performance, the monitoring entity must use a preventive standard, rather than the corrective standard embraced by Strickland $v$. Washington. ${ }^{41}$ With such a standard, the monitoring requirement will adequately and effectively serve its purpose, which is, to the extent practicable, to prevent incompetent performance. In other words, rather than searching to uncover actual instances of ineffective assistance under Strickland, the monitoring entity must search for conduct or circumstances that threaten the delivery of effective assistance. This does not mean, however, that the standard must seek to prevent all errors. Such a standard would impose enormous burdens on the government, as the monitoring entity essentially would have to shadow counsel, evaluating her every move.

As Part II explains, a properly balanced standard is one that requires the monitoring entity to look for obviously identifiable signs of actual or potential incompetence. Unlike a standard designed to prevent all error, this standard does not require the monitoring entity to look for potential claims or evaluate the wisdom of counsel's decisions. Instead, it requires the monitoring entity to look for outward signs of counsel's inability to perform competently, such as the existence of a physical or mental impairment, and for outward signs of counsel's failure to comply with the basic duties required of all capital postconviction counsel: the duty to investigate, the duty to raise all nonfrivolous claims, and the duty to file a timely postconviction petition. While such monitoring will not detect all problems with counsel's 
performance, it should detect a fairly wide range of problems, thereby increasing the likelihood of effective assistance.

Part II then explores how the government ought to remedy problems detected during the monitoring process. As that Part explains, the meaningfulness requirement demands protection for each capital inmate's right to effective assistance of counsel. Accordingly, the government must attempt to prevent counsel's conduct from interfering with the capital inmate's ability to have her claims decided on the merits. The basic remedies include (1) a written or oral notification to counsel identifying the problem, followed by additional monitoring; (2) an extension of time; and (3) the removal and substitution of counsel. But, as always, the meaningfulness requirement demands a balancing of the competing interests, and so the precise remedy (or combination of remedies) will depend not only on the nature of the problem with counsel's performance, but also on the weight of the government's interests in avoiding delay and achieving finality. Essentially, this means the remedy must not intrude on governmental interests any more than is necessary to solve the problem. It also means the capital petitioner is not entitled to an endless stream of remedies. If reasonable efforts to solve the problem nevertheless fail, then the capital inmate must bear the burden of counsel's error. While an imperfect solution, it properly balances the capital inmate's need for competent counsel with the government's interest in moving the postconviction process forward. And, in the end, monitoring will at least increase the likelihood of competent performance, which is a step in the right direction.

\section{Monitoring And the Due-Process-Based Meaningfulness REQUIREMENT}

\section{A. The Meaningfulness Requirement ${ }^{42}$}

The Supreme Court has consistently interpreted the Due Process Clause to contain what this author has called a "meaningfulness requirement," 43 applicable when the government "provides a right it has no obligation to provide and [when] that right is designed to protect either the fairness and reliability of the criminal trial or the individual rights of criminal

42. This author discussed the meaningfulness requirement in depth in a prior work. See McConville, supra note 13, at 67-80.

43. Id. at 69 . 
defendants." " To be meaningful, the right must be "designed to achieve its purpose. It [must be] 'adequate and effective' rather than a 'meaningless ritual' or a 'futile gesture." 44

The meaningfulness requirement is sensitive to context, so naturally the procedures required to make a voluntarily-provided right meaningful will not be the same in all situations. Instead, the demands of the meaningfulness requirement depend on the balancing of two factors: (1) the importance of the voluntarily-provided right, which is determined by examining the extent to which the right is designed to enhance the reliability of the criminal trial or to guard the defendant's individual rights; and (2) the weight of the government's interest in preserving sovereign authority over the criminal process ${ }^{46}$ As a general rule, the more important the voluntarily-provided right is to enhancing reliability of the criminal trial process, the more stringent the meaningfulness requirement becomes. ${ }^{47}$

In the direct appeal context, the meaningfulness requirement demands quite a bit from the government, because the direct appeal process is essential to the reliability of the criminal trial process, and hence, to protecting the criminal defendant's constitutional rights. ${ }^{48}$ In Griffin v. Illinois, ${ }^{49}$ for example, the Court held that when the government provides criminal defendants with a direct appeal as of right - a right it has no obligation to

44. $I d$.

45. Id. (quoting Evitts v. Lucey, 469 U.S. 387, 393 (1985); Griffin v. Illinois, 351 U.S. 12, 20 (1956); and Douglas v. California, 372 U.S. 353, 358 (1963)). The meaningfulness requirement would fall under what Professor Jerold Israel calls "free-standing due process," a term which refers to "the content of due process that stands apart from the incorporated guarantees." Jerold H. Israel, Free-Standing Due Process and Criminal Procedure: The Supreme Court's Search for Interpretive Guidelines, 45 ST. Lou IS. U. L.J. 303, 305 (2001); see id. at 377-78, 394 (describing the cases discussed in Part I of this Article as free-standing due process cases). Professor Israel argues that the Court has used free-standing due process to make a "significant contribution" to the "constitutional regulation of criminal procedure." Id. at 305. The cases used in this Part to demonstrate the existence and application of the meaningfulness requirement underscore this observation, as they all concern constitutional regulation of the criminal process. See infra notes 49-124 and accompanying text.

46. McConville, supra note 13 , at 70,80 .

47. See id. at 70-80. In Ross v. Moffitt, the Court ruled that the government had no constitutional obligation to provide counsel during discretionary direct review. Ross v. Moffitt, 417 U.S. 600, 615 (1974). Unlike direct appeals, the discretionary review process is less about enhancing reliability in an individual case and more about developing areas of the law for future general application. Id. at 615-16. In the Court's view, this goal can be achieved without counsel, rendering counsel an unnecessary ingredient in the meaningfulness analysis. See id. at 615; McConville, supra note 13, at 74-75.

48. See Griffin, 351 U.S. at 18 (stating that a direct appeal is an "integral part of the ... trial system for finally adjudicating the guilt or innocence of a defendant'); see also McConville, supra note 13, at 71 (explaining the meaningfulness requirement).

49. Griffin v. Illinois, 351 U.S. 12 (1956). 
provide - the government cannot charge indigent criminal defendants to receive a copy of the trial transcript if the transcript is necessary to bringing an effective appeal..$^{50}$ In these circumstances, denial of a transcript prevents such defendants from effectively availing themselves of the direct appeal process, rendering that process nothing more than an empty gesture. ${ }^{51}$ And, in Douglas v. California ${ }^{52}$ decided just a few years after Griffin, the Court held that when the government provides a direct appeal as of right, it must also provide counsel for those indigent criminal defendants who choose to pursue such an appeal. ${ }^{53}$ Without counsel, the Court reasoned, "the right to appeal does not comport with fair procedure," and is nothing more than "the right to a meaningless ritual." ${ }^{\prime 4}$ Counsel assists the defendant by discovering all relevant claims and presenting them to the appellate court in the most persuasive manner possible - things the defendant is ill-equipped to do if left to pursue the appeal on her own. ${ }^{55}$

The meaningfulness requirement generally requires much less of the government when the right involves postconviction review, for, in the Court's view at least, postconviction review is not integral to the reliability of the trial process, and any reliability interest it might serve will not always outweigh the state's interest in structuring its postconviction process in a manner it deems appropriate. ${ }^{56}$ As a result, the Court tends to apply the meaningfulness requirement more flexibly in the postconviction context, emphasizing the government's sovereign authority over its criminal processes. In Pennsylvania v. Finley, ${ }^{57}$ for example, the Court ruled that the government has no constitutional obligation to provide counsel for indigent criminal defendants seeking postconviction review. Such review, the Court reasoned, "is a

50. Id. at 18 .

51. Id. at 14. In Griffin, the Court made clear that the states need not "purchase a stenographer's transcript in every case where a defendant cannot buy it." Id. at 20. As the Court recognized, there might be some instances in which "other methods of reporting trial proceedings could be used" to satisfy the state's duty to make the appellate process "adequate and effective." Id. This flexibility is inherent in the meaningfulness requirement, as the meaningfulness analysis tends to balance the interests of the government with the interests of the criminal defendant. See McConville, supra note 13, at 70.

52. Douglas v. California, 372 U.S. 353 (1963).

53. Id. at 356-58. The Douglas right to counsel includes the right to have counsel file non-frivolous claims; it does not include the right to have counsel file frivolous claims. E.g., Jones v. Barnes, 463 U.S. 745, $751-54$ (1983).

54. Douglas, 372 U.S. at 357-58.

55. See id. at 355-56 (explaining that "unless the printed pages show that an injustice has been committed, [the defendant] is forced to go without a champion on appeal").

56. McConville, supra note 13, at 75-76.

57. Pennsylvania v. Finley, 481 U.S. 551 (1987). 
collateral attack that normally occurs only after the defendant has failed to secure relief through direct review of his conviction." 58 The defendant, in other words, already has had an opportunity to challenge the reliability of her conviction and sentence, and, at this point in the process, "fundamental fairness" ${ }^{\prime 9}$ requires much less of the government. Two years later, in Murray v. Giarratano, ${ }^{60}$ the Court used this same reasoning to extend Finley to the capital context, ruling that the government has no constitutional obligation to provide counsel to capital inmates who seek postconviction relief. ${ }^{61}$

Relying on the Court's meaningfulness cases, this author has argued that, even if the government possesses no constitutional obligation to supply counsel to capital inmates pursuing postconviction review, once the government voluntarily decides to do so, due process requires that the right be meaningful. ${ }^{62}$ And, to be meaningful, the right to postconviction counsel must include the right to effective assistance, which means the right to actual competent performance. ${ }^{63}$ The effectiveness guarantee, however, does not extend to counsel's entire performance, as such a guarantee would require a backward-looking, post-performance review of counsel's conduct. ${ }^{64}$ Because such reviews would greatly aggravate the government's interests in avoiding delay and achieving finality - interests that become much heavier at this stage of the process - they cannot be part of the meaningfulness requirement. Instead, the postconviction effectiveness guarantee extends to a part of counsel's performance - the part "that can be controlled through compliance with rigorous competency standards and through a mandatory duringperformance evaluation of counsel's conduct." ${ }^{95}$ As a result, when the government grants capital postconviction counsel, it must protect the right to

58. Id. at 557 .

59. Id. at 556 .

60. Murray v. Giarratano, 492 U.S. 1 (1989).

61. Griffin, Douglas, Finley, and Giarratano represent just four of many cases in which the Court has invoked the meaningfulness requirement to determine the scope of the government's obligations with respect to voluntarily-provided rights. For a discussion of other meaningfulness cases, see McConville, supra note 13 , at $69-80$.

62. Id. at $80-84$.

63. Id. at 67-110 (discussing the meaningfulness requirement as applied to statutory grants of capital postconviction counsel).

64. Id. at 104-07. The traditional effectiveness component attached to constitutional rights to counsel extends to counsel's entire performance and is enforced through a post-performance review. See Strickland v. Washington, 466 U.S. 668 (1984).

65. McConville, supra note 13, at 112. 
counsel with both competency standards and during-performance evaluations. ${ }^{66}$

To be sure, these methods of protection are imperfect from the capital defendant's standpoint. Nevertheless, they represent a proper balance of the competing interests, as they will increase the effectiveness of postconviction counsel without unduly aggravating the government's interests in preventing delay and achieving finality. ${ }^{67}$

\section{B. The Government's Continuing Obligations Under the Meaningfulness Requirement}

The meaningfulness requirement does not cease to operate once a court determines what is necessary to render a voluntarily-provided right meaningful. Instead, it continues to act as a constitutional limit on government action, even as the government goes about satisfying the original obligations imposed by the meaningfulness requirement. And it does so to help ensure that the government does not-intentionally or unintentionally - make an end-run around those original obligations. As demonstrated below, the government must continue to "safeguard" "vindicate" 69 not only the original obligations of the meaningfulness requirement, but also the voluntarily-provided right itself.

Take the Griffin rule as an example. Two years after Griffin, in Eskridge v. Washington State Board of Prison Terms and Paroles ${ }^{70}$ the Supreme Court held that if the indigent defendant needs a free trial transcript to "effectively prosecute his appeal," then the government could not condition its receipt upon the trial court's determination that the trial was unreliable or unfair. ${ }^{71}$ As the Court explained, the trial court's determination that the defendant had received a fair trial "cannot be an adequate substitute for the right to full appellate review." $"$ While the government need not supply a free transcript

66. But see Hammel, supra note 9, at 383-88 (agreeing in principle with this author's proposal for during-performance reviews, but arguing that courts are unlikely to interpret the Constitution in a manner that would require the government to provide such reviews).

67. McConville, supra note 13, at 110.

68. E.g., Smith v. Robbins, 528 U.S. 259, 264-65 (2000).

69. Id. at 273 .

70. Eskridge v. Wash. State Bd. of Prison Terms \& Paroles, 357 U.S. 214 (1958).

71. Id. at 215-16.

72. Id. at 216. The defendant in Eskridge challenged the rule on both equal protection and due process grounds. $I d$. at 215 . While the Court in Eskridge did not indicate clearly the basis for its decision, a sensible reading of the opinion indicates that the Court relied upon both clauses. The Court cites Griffin, 
to every indigent defendant, the government may not use the trial court as a filter for meritless cases, at least where the transcript is the only available evidence of what went on at trial. ${ }^{73}$ In short, the government's transcript rule failed to protect the purpose of providing the free transcript in the first place, which is to ensure that indigent criminal defendants receive a meaningful opportunity to present their claims on appeal. ${ }^{74}$

In Lane v. Brown, ${ }^{75}$ the Court invoked Griffin to strike down an Indiana rule conditioning an indigent defendant's receipt of a transcript for use in a state postconviction appeal on the public defender's opinion that the appeal has merit. ${ }^{76}$ As the Court explained, Indiana's rule "confers upon a state officer outside the judicial system power to take from an indigent all hope of any appeal at all." ${ }^{977}$ In other words, Indiana implemented the Griffin transcript obligations in a manner that undermined the right to a transcript and rendered meaningless the voluntarily-provided right to a postconviction appeal. $^{78}$

which itself relied on both clauses, and uses the language of both due process and equal protection in its short opinion. See id. at 216 (finding that the state rule was not an "adequate substitute for full appellate review available to all defendants in Washington who can afford the expense of a transcript") (emphasis added); id. ("[D]estitute defendants must be afforded as adequate appellate review as defendants who have money enough to buy transcripts.") (internal citation omitted) (emphasis added). Thus, Eskridge provides a fine example of the meaningfulness requirement.

73. Id. at 215-16.

74. See id.

75. Lane v. Brown, 372 U.S. 477 (1963).

76. Id. at 480-81, 485. The Brown Court made it clear that Griffin's rule "also applies to state collateral proceedings ... even though the State has already provided one review on the merits." Id. at 484-85. As the Court explained:

Destitute defendants ... must be afforded as adequate appellate review as defendants who have money enough to buy transcripts. . . . This principle is no less applicable where the State has afforded an indigent defendant access to the first phase of its appellate procedure but has effectively foreclosed access to the second phase of that procedure solely because of his indigency.

$I d$. at 483-84 (internal citations and quotations omitted).

77. Id. at 485 .

78. While Brown decided the case on equal protection grounds, it nevertheless provides a useful example of the government's continuing obligation under the meaningfulness requirement. The Brown Court cites and applies the Griffin analysis, which utilized both equal protection and due process principles. See Brown, 372 U.S. at 483-84; Griffin v. Illinois, 351 U.S. 12, 17-19 (1956). Moreover, as the Court recently explained in Smith v. Robbins, 528 U.S. 259 (2000), both clauses underlie the meaningfulness requirement:

As we have admitted on numerous occasions, "the precise rationale for the Griffin and Douglas lines of cases has never been explicitly stated, some support being derived from the Equal Protection Clause of the Fourteenth Amendment and some from the Due Process Clause of that Amendment." But our case law reveals that, as a practical matter, the two Clauses largely converge to require that a State's procedure "afford adequate and effective appellate review to indigent defendants."

Id. at 276 (emphasis added). 
The decisions discussing the contours of the Douglas right to counsel on direct appeal (which, as explained above, is a product of the meaningfulness requirement) also vividly demonstrate the government's continuing burden under the Due Process Clause. In Evitts v. Lucey, ${ }^{79}$ for example, the Court considered whether the Douglas right to counsel "comprehends the right to effective assistance of counsel." ${ }^{, 80}$ Answering that question in the affirmative, the Court emphasized that the Douglas right to counsel is necessary to make the direct appeal meaningful. ${ }^{81}$ Counsel assists the defendant by acting as "an active advocate, rather than a mere friend of the court assisting in a detached evaluation of the appellant's claim." ${ }^{\prime 2}$ Accordingly, the government may not satisfy its due process obligations by supplying any lawyer, but rather must supply a lawyer who actually delivers effective assistance to the defendant on appeal. ${ }^{83}$ As Evitts explained: "nominal representation on an appeal as of right—like nominal representation at trial— does not suffice to render the proceedings constitutionally adequate; a party whose counsel is unable to provide effective representation is in no better position than one who has no counsel at all." ${ }^{\prime 4}$ In short, Evitts imposed the effectiveness guarantee to protect not only the Douglas right to counsel, but also the right to a meaningful appeal.

An even more obvious example of the government's continuing obligation under the meaningfulness requirement is provided by Anders $v$. California, ${ }^{85}$ which, like Evitts, elaborated on the Douglas right to counsel. In Anders, the Court considered whether counsel appointed to represent an indigent criminal defendant on direct appeal could, consistent with the due process and equal protection guarantees, withdraw from representation if she determines the appeal to be meritless. ${ }^{86}$ California courts permitted withdrawal in such circumstances, provided that counsel and the appellate court follow a specified procedure. ${ }^{87}$ That procedure required "appointed counsel [to] thoroughly stud[y] the record, consult[] with the defendant and trial counsel and conscientiously conclude[], and so advise[] the appellate

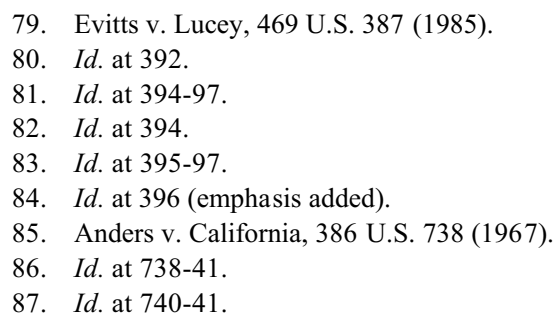


court, that there are no meritorious grounds of appeal." 88 The appellate court must then review the record, and if the court "is satisfied from its own review of the record ... that appointed counsel's conclusion is correct ... [ $\mathrm{t}] \mathrm{he}$ appeal then proceeds without the appointment of other counsel." ${ }^{\prime 89}$ Anders's counsel studied the record, consulted with petitioner, and determined there were no nonfrivolous claims. He filed a short "no-merit letter" ${ }^{90}$ with the court, stating his conclusion about the meritless nature of the case. ${ }^{91}$ Anders then moved for new counsel, but the court denied the motion. ${ }^{92}$ Petitioner subsequently filed his own brief and, unsurprisingly, lost the appeal. ${ }^{93}$

The Court invalidated California's procedures, ruling that they violated both due process and equal protection guarantees. ${ }^{94}$ Like Evitts, the Court emphasized that "[t]he constitutional requirement of substantial equality and fair process can only be attained where counsel acts in the role of an active advocate in behalf of his client, as opposed to that of amicus curiae." ${ }^{95}$ As the Court explained in a later case, this right to an advocate does not include the right to counsel to file a frivolous appeal. ${ }^{96}$ But it does include, "in all cases, ... the right to have an attorney, zealous for the indigent's interests, evaluate his case and attempt to discern nonfrivolous arguments." ${ }^{.97}$ Allowing counsel to withdraw when she believes the case is frivolous creates a risk of undermining this right to counsel, for counsel might seek to withdraw without performing an adequate review of the record for arguably meritorious claims ${ }^{98}$ If this happens, and the appellate court grants the withdrawal request, then it

88. Id. at 741 n.2 (citing In re Nash, 61 Cal. 2 d 491 (Cal. 1964)).

89. Id.

90. Id. at 745 .

91. Id. at 742. The letter stated: "'I will not file a brief on appeal as I am of the opinion that there is no merit to the appeal. I have visited and communicated with Mr. Anders and have explained may [sic] views and opinions to him. ... [H] e wishes to file a brief in this matter on his own behalf."' $I d$.

92. Id. at 740 .

93. Id. at $739-40$

94. Id. at 741 ("We have concluded that California's action does not comport with fair procedure and lacks that equality that is required by the Fourteenth Amendment.") (emphasis added).

95. Id. at 744

96. Smith v. Robbins, 528 U.S. 259, 278 (2000) (internal citations omitted).

97. Id. at $278 \mathrm{n} .10$ (internal citations omitted).

98. See Robbins, 528 U.S. at 278 (recognizing that allowing withdrawal for meritless appeals could "swallow[] the right [to counsel] itself'); $i d$. at 294 (noting the necessity for "some reasonable assurance that the lawyer has not relaxed his partisan instinct prior to refusing [to file a brief on the merits], in which case the court's review could never compensate for the lawyer's failure of advocacy") (Souter, J., dissenting). 
is as if counsel had never been appointed..$^{99}$ And as Douglas teaches, there can be no meaningful direct appeal without counsel.

Applying the meaningfulness analysis, the Court ruled that the government must establish safeguards designed to ensure that withdrawal does not eviscerate the right to counsel, and, in turn, the right to a meaningful appeal. California's procedure was constitutionally inadequate because it did not require counsel to act as an advocate, thereby leaving both the defendant and the court of appeals in a lurch. "[C]ounsel's bare conclusion" 100 that the case lacked merit forced the defendant to "shift entirely for himself" in presenting his claims, ${ }^{101}$ and required the appellate court to review "the cold record ... without the help of an advocate."102 In short, "California's procedure did not furnish petitioner with counsel acting in the role of an advocate nor did it provide that full consideration and resolution of the matter as is obtained when counsel is acting in that capacity."103

Asserting that "[c] ounsel should, and can with honor and without conflict, be of more assistance to his client and to the court," the Court recommended a procedure that would protect the right to counsel and, in turn, the right to a meaningful appeal. ${ }^{104}$ Under this procedure, counsel must accompany the request to withdraw with what is now commonly referred to as an "Anders brief," raising "anything in the record that might arguably support the appeal." "105 The purpose of the brief is not only to provide "that advocacy which a nonindigent defendant is able to obtain[, but] . . . also [to] induce the court to pursue all the more vigorously its own review because of the ready references not only to the record, but also the legal authorities as furnished by counsel." 106 If, after conducting its own review of the record, the appellate

99. See Randall L. Hodgkinson, No-Merit Briefs Undermine the Adversary Process in Criminal Appeals, 3 J. App. PraC. \& Process 55, 58 (2001). Drawing upon his own experiences as a judicial clerk and a public defender, Mr. Randall L. Hodgkinson argues against allowing withdrawal for lack of merit because it "discourages advocacy." Id. As he explains, "if attorneys complete cursory reviews and conclude that cases are losers, they have little motivation to do anything but file no-merit briefs. The process of finding issues through an advocacy process is lost." Id. at 58-59. In the end, "a no-merit brief procedure ... encourages appellate defense counsel to not represent their clients. It sets up a system in which an accused, with little recourse, does not even get an adequate review of his or her conviction." Id. at 60 .

100. Anders, 386 U.S. at 742.

101. Id. at 745 .

102. Id.

103. Id. at 743 .

104. Id. at 744 .

105. Id.

106. Id. at 745 . 
court finds "the case is wholly frivolous," it may then grant the withdrawal request. ${ }^{107}$ But, if the court finds "any of the legal points arguable on their merits," 108 then it must appoint new counsel to represent the defendant. Such action by the appellate court ensures that indigent criminal defendants who have nonfrivolous issues are not left without counsel on appeal. ${ }^{109}$

More than thirty years after Anders, the Court reaffirmed that the Anders brief and its accompanying procedure are a product of the meaningfulness requirement, designed to protect both the right to counsel and the right to a meaningful appeal. In Smith v. Robbins, ${ }^{110}$ the Court described Anders as holding "that, in order to protect indigent defendants' constitutional right to

107. Id. at 744 .

108. Id. Below is a fuller description of the recommended procedures:

[I]f counsel finds his case to be wholly frivolous, after a conscientious examination of it, he should so advise the court and request permission to withdraw. That request must, however, be accompanied by a brief referring to anything in the record that might arguably support the appeal. A copy of counsel's brief should be furnished the indigent and time allowed him to raise any points that he chooses; the court-not counsel-then proceeds, after a full examination of all the proceedings, to decide whether the case is wholly frivolous. If it so finds it may grant counsel's request to withdraw and dismiss the appeal insofar as federal requirements are concerned, or proceed to a decision on the merits, if state law so requires. On the other hand, if it finds any of the legal points arguable on their merits (and therefore not frivolous) it must, prior to decision, afford Id. the indigent the assistance of counsel to argue the appeal.

109. Id. at 745; see also Smith v. Robbins, 528 U.S. 259, 277 (2000) (stating Anders procedures are designed "to ensure that those indigents whose appeals are not frivolous receive the counsel and merits brief required by Douglas"). The Court has continued to refine the rules regarding withdrawal procedures, and, in doing so, has continued to apply the meaningfulness requirement. In McCoy v. Court of Appeals, 486 U.S. 429 (1988), the Court upheld a Wisconsin rule that required counsel, when seeking withdrawal for lack of merit, to include in the Anders brief "a discussion of why the issue[s] lack[] merit." Id. at 430. This rule did not undermine the Douglas right to counsel and, thus, did not violate due process because it simply required counsel to "act with candor" when presenting her reasons for withdrawal. Id. at 440. Moreover, it served the same purpose as the Anders brief itself, which is to assist the court not only in determining whether counsel has "provided the client with a diligent and thorough search of the record for any arguable claim that might support the client's appeal," but also in conducting its own review of the record. Id. at 442. The Court also concluded that the Wisconsin rule may actually "forestall some motions to withdraw," because counsel might, in the course of "preparing a written explanation for his or her conclusion," discover nonfrivolous claims. $I d$.

In Penson v. Ohio, 488 U.S. 75 (1988), the Court ruled, inter alia, that appellate courts may not grant a motion to withdraw without submission of an Anders brief, or before the court has undertaken its own evaluation of the record for possible error. Id. at 81-83. Both the Anders brief and the independent review of the record by the appellate court help protect the Douglas right to counsel by allowing the court an opportunity to determine whether counsel has served her client's interests by diligently examining the record for nonfrivolous claims. Id. at 82-83. Moreover, as the Court stated in a later case, "the Penson procedure permitted a basic violation of the Douglas right to have counsel until a case is determined to be frivolous." Robbins, 528 U.S. at 280.

110. Robbins, 528 U.S. 259. 
appellate counsel, courts must safeguard against the risk of granting . . . requests [for withdrawal] in cases where the appeal is not actually frivolous." 111 In other words, the government has an obligation to ensure that procedures relating to withdrawal of counsel "adequately safeguard" 112 or "vindicate the constitutional right to appellate counsel announced in Douglas." 113 Such is the language of the meaningfulness requirement.

At issue in Robbins was whether the specific Anders procedure was constitutionally required, or whether the states could establish procedures different from Anders. Holding that the states could indeed establish their own procedures, the Robbins Court explained that "the procedure we sketched in Anders is a prophylactic one; the States are free to adopt different procedures, so long as those procedures adequately safeguard a defendant's right to appellate counsel." 114 Such procedures, the Court further explained, must provide "the adequate and effective appellate review that the Fourteenth Amendment requires." 115 This is accomplished as long as the "procedure reasonably ensures that an indigent's appeal will be resolved in a way that is related to the merit of that appeal." 116

111. Id. at 264 (emphasis added); see id. at 276 (describing an "Anders procedure [as] merely one method of satisfying the requirement of the Constitution for indigent criminal defendants") (emphasis added).

112. Id. at 265 .

113. $I d$. at 273

114. $I d$. at 265 (emphasis added). For an argument against no-merit withdrawals in general, and the Robbins decision in particular, see James E. Duggan \& Andrew W. Moeller, Make Way for the ABA: Smith v. Robbins Clears a Path for Anders Alternatives, 3 J. App. PraC. \& Process 65 (2001) (criticizing Robbins as providing too much "leeway" to the states in establishing withdrawal procedures, and arguing in favor of $\mathrm{ABA}$ approach, which would prohibit no-merits withdrawal requests and require counsel to file brief on the merits).

115. Robbins, 528 U.S. at 279; see also id. at 276 ("California's system does not violate the Fourteenth Amendment, for it provides 'a criminal appellant pursuing a first appeal as of right [the] minimum safeguards necessary to make that appeal 'adequate and effective.'”') (quoting Evitts v. Lucey, 469 U.S. 387, $392(1985))$.

116. Robbins, 528 U.S. at 278-79. In Robbins, the Court held that California's revised procedure - called the "Wende procedure" - satisfied this standard. Id. at 265. The Wende procedure requires counsel to file a brief reciting the factual background and procedural history of the case, but not arguable issues. $I d$. The brief must contain citations to the record, and counsel must "attest[] that he has reviewed the record, explained his evaluation of the case to his client, provided the client with a copy of the brief, and informed the client of his right to file a pro se supplemental brief." Id. The brief does not, however, contain any statement regarding counsel's substantive view of the case. And, in the brief, rather than requesting withdrawal, counsel "requests that the court independently examine the record for arguable issues." Id. at 265. The appellate court then reviews the record in its entirety, and, if it finds no nonfrivolous issues, it affirms the decision below. Id. at 265-66. If, on the other hand, the appellate court determines that the appeal contains nonfrivolous issues, it orders counsel to file a merits brief. Id. Comparing Wende to procedures considered in prior cases, the Court concluded that the Wende procedure 
The talk in Robbins of a "prophylactic" rule does not undermine the conclusion that Anders applied the meaningfulness requirement and thereby established a constitutional obligation to safeguard the right to counsel and the right to a meaningful appeal. The Court's use of the term "prophylactic" means simply that the Constitution does not "compel the Anders procedure."117 It does not signal the lack of a constitutional obligation to establish meaningful withdrawal procedures. As the Court plainly stated, "the Anders procedure is merely one method of satisfying the requirements of the Constitution for indigent criminal appeals." 118 Thus, the Court's use of the

"affords adequate and effective appellate review for criminal defendants." Id. at 284. As the Court explained, the Wende procedure "requires both counsel and the court to find the appeal . . . lacking in arguable issues," thereby ensuring two levels of review for possible error. Id. at 280. Moreover, the Wende procedure adequately protected the Douglas right to counsel "because counsel does not move to withdraw and because the court orders briefing if it finds arguable issues." Id.

For arguments against Wende review, see David M. Majchrzak, The Impropriety of a Constitutional Doctrine: Why Wende Review Should Be Terminated, 23 T. JefFerson L. Rev. 267 (2001); see also Duggan \& Moeller, supra note 114.

117. Smith v. Robbins, 528 U.S. 259, 273 (2000). See Susan R. Klein, Identifying and (Re)formulating Prophylactic Rules, Safe Harbors, and Incidental Rights in Constitutional Criminal Procedure, 99 Mich. L. Rev. 1030, 1042-43 (2001) (describing Anders as a "prophylactic" rule that is "not required by the text of the constitutional clauses at issue"). But see Duggan \& Moeller, supra note 114, at 87-90 (arguing that specific procedures outlined in Anders were constitutionally mandatory rather than a "suggested procedure" to satisfy constitutional obligation).

Scholars made a similar argument about the Miranda warnings. See Robert Litt, Will Miranda Survive? Dickerson v. United States: The Right To Remain Silent, the Supreme Court, and Congress, 37 Am. Crim. L. Rev. 1165, 1174-75 (2000) (arguing that the "Miranda warnings ... are not constitutionally required," but that "the holding" of Miranda is so required); $i d$. (arguing that although "the specific warnings were not constitutionally required, the requirement of safeguards to protect the privilege was constitutionally required"); see also Klein, supra note 117, at 1032 (arguing that "the Miranda decision can best be explained, both normatively and descriptively, as a constitutional prophylactic rule designed to assist the Court in protecting the privilege against self-incrimination"). Of course, the Supreme Court rejected this argument in Dickerson v. United States, 530 U.S. 428, 432 (2000). For a criticism of Dickerson, see Klein, supra note 117, at 1071-75 (arguing that the Court should have "acknowledg[ed] Miranda as a prophylactic rule").

118. Robbins, 528 U.S. at 276 (emphasis added); see also id. at 273 (explaining that the Anders procedure "is just a 'prophylactic framework' that we established to vindicate the constitutional right to appellate counsel announced in Douglas") (quoting Pennsylvania v. Finley, 481 U.S. 551, 555 (1987)); see also Dan T. Coenen, The Rehnquist Court, Structural Due Process, and Semisubstantive Constitutional Review, 75 S. CAL. L. REv. 1281, 1345-47 (2002) (explaining that the "Robbins [decision] in effect recast a longstanding criminal procedure precedent in the guise of a common-law-like rule that invited states to meet their constitutional responsibilities in a much broadened set of new ways").

Other commentators likewise view Anders as establishing a constitutional rule that states must establish some procedure to protect appeal and/or counsel rights. See Coenen, supra note 118, at 1346 (explaining that Anders "held that the Constitution requires states to take meaningful steps to protect the appeal rights of convicted defendants represented by appointed counsel"); $i d$. at 1347 (explaining that states may "meet their constitutional responsibilities [of establishing procedures to protect appeal rights] in a 
term "prophylactic" is better understood as evidence of the Court's attempt to promote federalism interests ${ }^{119}$-interests that represent a core part of the meaningfulness requirement. ${ }^{120}$ In Robbins itself, the Court explained that "it is more in keeping with our status as a court, and particularly with our status as a court in a federal system, to avoid imposing a single solution on the States from the top down." "121 Accordingly, the Anders procedure was not a "straightjacket" 122 for the states, but rather an example of how the states might go about satisfying their constitutional obligations to ensure a meaningful appeal. ${ }^{123}$ With true federalism optimism, the Court concluded that "[s]tates

much broadened set of new ways"); Israel, supra note 45, at 394 (explaining that under Anders and Robbins "due process ... demands certain minimum standards in allowing withdrawal by counsel who believes the appeal is frivolous"); Klein, supra note 117, at 1042 (explaining that the Anders Court "held that the Due Process and Equal Protection Clauses required some procedure to protect an indigent defendant's constitutional right to appellate counsel"); Erik Luna, Constitutional Road Maps, 90 J. CRIM. L. \& CRIMINOLOGY 1125, $1192 \mathrm{n} .359$ (listing Anders and Smith as decisions which offer examples of procedures that would satisfy constitutional requirements).

119. For an interesting discussion of prophylactic rules and how they can promote federalism interests, see Klein, supra note 117, at 1052-59.

120. Professor Jerold Israel's interpretation of the Court's "free-standing due process" decisions reinforces the importance of federalism in the Court's application of the meaningfulness requirement. Israel, supra note 45, at 387. Professor Israel explains that, when determining the scope of free-standing due process protections, the Court, at least in "the post-incorporation era," has been motivated in part by a desire to reduce interference with state sovereignty. Id. Quoting material from Robbins, Professor Israel explains the due process cases as follows:

[The Court] stresses the primary responsibility of the states in shaping their own criminal justice

systems. It notes, for example, that due process rulings should be careful to "evaluate state

procedures one at a time, as they come before us," and not "cavalierly "impede the States ability to

serve as laboratories for testing solutions to novel legal problems."”

Id. at 398-99 (quoting Robbins, 528 U.S. at 275).

Professor Coenen's recent work on "constitutional common law rules" also provides support for the view that the Court applies the meaningfulness requirement in a manner sensitive to state interests. Coenen, supra note 118, at 1340. He argues that the Rehnquist Court has demonstrated a tendency to establish "constitutional common law rules [that] protect substantive constitutional values." Id. These rules instigate "interbranch dialogue," $i d$. at 1345 , because the legislature is free to override them, provided that it "adopts some other rule that implements in an alternative way the constitutional values the constitutional common law rule was meant to protect." Id. at 1341. In Professor Coenen's view, Robbins interprets Anders as establishing a constitutional common law rule. $I d$. at 1347. Interestingly, Professor Coenen suggests that the use of such rules "might on balance reduce, rather than expand, individual liberty." Id. at 1350.

121. Robbins, 528 U.S. at 275 ; see also id. at 274-75 (providing examples of cases touting this federalism principle).

122. $I d$. at 273 .

123. Id. at 276. For a thought-provoking discussion of the Court's efforts to "spur political discourse and lawmaking through the crafting of opinions," see Luna, supra note 118, at 1126 . Indeed, Professor Luna argues that both Anders and Robbins could be viewed as encouraging such discourse. Id. at 1192 n.359. 
may — and, we are confident, will—craft procedures that, in terms of policy, are superior to, or at least as good as, that in Anders." ${ }^{24}$

As the discussion in this Part demonstrates, once the government voluntarily provides a right designed to enhance the reliability of the criminal process, due process requires that the government make the right meaningful — which is to say that it must be "adequate and effective." 125 And the commands of due process continue to bind the government as it seeks to comply with the meaningfulness requirement. Basically, the governmentmust structure the voluntarily-provided right so that it achieves its purpose. Stated differently, the government must ensure that the procedures it creates to support the voluntarily-provided right do not, in the end, undermine that right.

Moreover, while the meaningfulness requirement at times imposes a constitutional minimum - that is, procedures that must be provided to satisfy due process - it is not entirely insensitive to federalism concerns. So, while the government has no choice but to provide counsel on direct appeal (as well as effective assistance of that counsel), ${ }^{126}$ the government retains some discretion regarding the procedures for providing counsel, such as whether, and how, to allow appointed counsel to withdraw if she believes the case contains only frivolous issues. ${ }^{127}$ The limit, of course, is that the government must ensure that the procedure it establishes adequately (and actually) safeguards the voluntarily-provided right. ${ }^{128}$

\section{The Structure and Substance of the Monitoring Requirement}

The monitoring requirement is to the right to capital postconviction counsel what the right to counsel is to the direct appeal: each is required to render the original voluntarily-provided right meaningful. And, just as the government cannot satisfy its obligation to provide counsel on direct appeal by appointing any lawyer regardless of competence (or allowing withdrawal without assurance that the lawyer has adequately reviewed the case), neither can the government satisfy its obligation to monitor the performance of postconviction counsel by setting up any procedure for reviewing counsel's performance during the postconviction process. In other words, the system created to monitor capital postconviction counsel must be adequate and

124. Robbins, 528 U.S. at 276.

125. E.g., Evitts v. Lucey, 469 U.S. 387, 393 (1985); Griffin v. Illinois, 351 U.S. 12, 20 (1956).

126. See Evitts, 469 U.S. at 394-96; Douglas v. California, 372 U.S. 353, 356-57 (1963).

127. See Robbins, 528 U.S. at 265.

128. See id. at 273 . 
effective - it must protect the right to monitoring and, in turn, the right to effective capital postconviction counsel. The more difficult question, however, is how to go about protecting these rights, thus ensuring that they remain meaningful.

In fashioning a constitutionally adequate monitoring procedure, four issues arise: (1) who should monitor counsel's performance; (2) what standard should the monitoring entity use when reviewing counsel's performance; (3) what aspects of counsel's performance should the monitoring entity investigate; and (4) what remedies are appropriate in the event monitoring reveals a problem. This Part examines each issue in turn.

\section{A. The Monitoring Entity}

Two basic alternatives exist with respect to who should perform the actual monitoring function: the courts or an entity independent of the courts. Perhaps not surprisingly, states appear to prefer the courts as the monitoring entity. ${ }^{129}$ The American Bar Association, on the other hand, recommends that

129. Florida requires the postconviction court to monitor counsel's performance. FLA. Stat. AnN. $\S 27.711$ (12) (West Supp. 2003) ("The court shall monitor the performance of assigned counsel to ensure that the capital defendant is receiving quality representation. The court shall also receive and evaluate allegations that are made regarding the performance of assigned counsel."). Colorado and Texas, both of which appear to authorize some form of postconviction monitoring, similarly rely on postconviction courts to perform the monitoring function. COLO. R. CRIM. P. 32.2(d) (West 2004) (authorizing the trial court and the state supreme court to impose sanctions for violation of postconviction rules); Tex. Code Crim. Proc. ANN. art. $11.071 \S \S 4(d), 4 \mathrm{~A}(\mathrm{a}), 4 \mathrm{~A}(\mathrm{~b})(3)$ (Vernon Supp. 2004-2005) (authorizing postconviction courts to appoint new counsel if original counsel fails to comply with filing deadline); see also Ex Parte Kerr, 64 S.W.3d 414, 421 (Tex. Crim. App. 2002) (noting that "trial courts who make the original appointment of habeas counsel ... have the authority to monitor the progress and timely filing of an initial application for a writ which qualifies as one which seeks relief from a judgment imposing a penalty of death") (internal quotation omitted). Judges in New York arguably perform a monitoring function when they exercise the power to "remove from their roster of attorneys any [capital postconviction] attorney who, in the Court's judgment, has not provided competent, thorough representation." N.Y. Cт. R. § 515.2(6)(b) (McKinney 2002). Finally, courts also perform the monitoring function in both Louisiana and Ohio, which expressly provide for monitoring of capital counsel at trial and on direct appeal, though not during state postconviction proceedings. See La. Rev. Stat. Ann. Rule XXXI ch. VII, pt. VII (West Supp. 2004) ("Attorneys certified within the guidelines of this Chapter shall be monitored to ensure eligibility."); id. at Louisiana Standards on Indigent Defense Standard 7-7.3 ("[A]n attorney's eligibility to represent an indigent client may not be reviewed, except by a court of proper jurisdiction, on the basis of conduct involving a case in which the attorney is presently actively representing the indigent client."); OHIO REV. Code AnN. Sup. CT. R. 20.V (West 2000) ("The appointing court should monitor the performance of assigned counsel to ensure that the defendant is receiving competent representation.").

California, which appears to authorize, if not implicitly require, monitoring of postconviction counsel, also appears to allow both the courts and a separate, though perhaps technically not independent, entity to perform the monitoring function. For example, it requires capital postconviction counsel to file a 
monitoring at the postconviction level be performed by an independent entity that oversees recruitment, eligibility, and appointment of capital counsel. ${ }^{130}$ Each alternative is discussed below.

\section{Judicial Monitoring}

Because monitoring involves reviewing counsel's performance during the actual postconviction process, one would naturally look, at least at first, to the courts. This is not just because the judge assigned to entertain a particular postconviction case is in a position to know (or at least to discover) when counsel might be performing inadequately, but also because the judge has a duty to oversee the proceedings and ensure they are conducted fairly. In the context of improving the effectiveness of criminal trial counsel, observers have long suggested that the trial judge perform a monitoring function. ${ }^{131}$ Judge William Schwarzer - who as a federal district court judge assuredly was in a position to know-explained that trial judges must monitor counsel performance because they "have the duty and the authority to protect the right to effective counsel." ${ }^{132}$ And, in the words of Professor Richard Klein, who

"confidential status report [with the court] ... every 60 days," suggesting that the court would perform the monitoring function. Cal. Sup. Ct., Policies Regarding Cases Arising from Judgments of Death, Policy 4B. At the same time, however, California legislation expressly authorizes the California Habeas Corpus Resource Center, an entity located in the state judicial branch, "[t]o provide ... case progress monitoring as needed." CAL. Gov'T CODE $§ 68661$ (j) (West 1997 \& Supp. 2004).

For a compilation of standards regarding issues surrounding counsel appointment, see Department of Justice, Compendium of Standards for Indigent Defense Systems: A Resource Guide for Practitioners and Policymakers, Vol. III, Standards for Capital Case Representation, at 7, B1-B39 (2000).

130. See ABA Recommendations, supra note 31, at 254-55 ("The appointing authority shall . . periodically review the rosters, monitor the performance of all attorneys appointed, and withdraw certification from any attorney who ... fails to meet high performance standards in a case to which the attorney is appointed."); 2003 ABA Guidelines, supra note 2, at Guideline 7.1, at 970 ("The Responsible Agency should monitor the performance of all defense counsel to ensure that the client is receiving high quality legal representation.”).

131. David L. Bazelon, The Realities of Gideon and Argersinger, 64 Geo. L.J. 811, 830-31 (1976) (arguing for judicial monitoring of trial counsel); Klein, supra note 40, at 564-84 (same); Levine, supra note 40, at 1426-35 (same); Schwarzer, supra note 40, at 649-65 (same); Tague, supra note 40, at 161-65 (same). Cf. Daniel J. Meltzer, State Court Forfeitures of Federal Rights, 99 HARv. L. Rev. 1128, 1235-36 (1986) (arguing in favor of broader rule excusing procedural defaults, and recognizing that such a rule might in turn encourage judges to assist in preventing procedural defaults at the state level).

132. Schwarzer, supra note 40 , at 641 . Judge Schwarzer believed that monitoring is necessary to preserve the adversary process. $I d$. at 636 (" $[\mathrm{P}]$ rophylactic action by the trial judge is consistent with our commitment to the adversary system ...."); id. at 639 ("When it appears in the course of litigation that a lawyer's performance is falling short, it should be the trial judge's responsibility, as the person responsible for the manner in which justice is administered in his court, to take appropriate action.”). Judge Schwarzer also pointed out that "[m]aking judgments about attorney competence is not foreign to the trial judge." Id. 
reached a similar conclusion, "It is properly the court's responsibility to ensure that the counsel it appoints to represent the indigent acts in accordance with professionally accepted standards of competent representation." 133

Both Judge Schwarzer and Professor Klein emphasized that the Supreme Court has endorsed the vision of the trial court as the protector of the fairness and reliability of the criminal process in general, and of the right to effective counsel in particular. ${ }^{134}$ In Glasser v. United States,${ }^{135}$ for example, the Court emphasized the trial court's general "duty of seeing that the trial is conducted with solicitude for the essential rights of the accused."136 Speaking specifically about protecting the right to counsel, the Court in McMann v. Richardson ${ }^{137}$ asserted: "[I]f the right to counsel guaranteed by the Constitution is to serve its purpose, defendants cannot be left to the mercies of the incompetent counsel, and ... judges should strive to maintain proper standards of performance by attorneys who are representing defendants in criminal cases in their courts. ${ }^{, 138}$ In short, as the Court stated eight years after McMann: "It is the judge, not counsel, who has the ultimate responsibility for the conduct of a fair and lawful trial." 139

at 635 n. 12 .

133. Klein, supra note 40, at 532. See also Ivan K. Fong, Ineffective Assistance of Counsel at Capital Sentencing, 39 Stan. L. Rev. 461, 494-95 (1987) (arguing that the trial judge's obligation to monitor capital counsel during sentencing stage with respect to presentation of mitigating evidence is "an extension of the trial judge's appointment of counsel"). The courts have long recognized their authority in this area. As the Fifth Circuit stated in United States v. Dinitz: "Traditionally, courts enjoy broad discretion to determine who shall practice before them and to monitor the conduct of those who do. Since attorneys are officers of the courts before which they appear, such courts are necessarily vested with the authority, within certain limits, to control attorneys' conduct." United States v. Dinitz, 538 F.2d 1214, 1219 (5th Cir. 1976) (emphasis added) (citing cases).

134. See Klein, supra note 40, at 540 (citing Glasser v. United States, 315 U.S. 60 (1942), McMann v. Richardson, 397 U.S. 759 (1970), and Estelle v. Williams, 425 U.S. 501 (1976)); Schwarzer, supra note 40, at 641 (citing McMann v. Richardson, 397 U.S. 759 (1970)); see also Tague, supra note 40, at 141 and n.171 (citing McMann, 397 U.S. 759 (1970), and Estelle, 425 U.S. 501 (1976)).

135. Glasser, 315 U.S. 60 (1942).

136. Id. at 71 .

137. McMann, 397 U.S. 759 (1970).

138. Id. at 771 .

139. Lakeside v. Oregon, 435 U.S. 333, 341-42 (1978). See also Estelle, 425 U.S. at 501, 503 ("[C]ourts must be alert to factors that may undermine the fairness of the fact-finding process.") (internal quotations omitted).

Admonitions similar to these also appear in both federal and state court decisions. See, e.g., Smith v. Lockhart, 923 F.2d 1314, 1320 (8th Cir. 1991) ("When a defendant raises a seemingly substantial complaint about counsel, the judge 'has an obligation to inquire thoroughly into the factual basis of defendant's dissatisfaction."') (quoting United States v. Hart, 557 F.2d 162, 163 (8th Cir. 1977)); People v. McKenzie, 668 P.2d 769, 776 (Cal. 1983) ("The court has the authority to take whatever steps [are] necessary to see that no conduct on the part of any person obstructs the administration of justice.") (internal 
The role of the judge in postconviction proceedings is no less important or onerous than it is in the trial setting. While the postconviction process is commonly characterized as "collateral" to the trial and direct appeal, this characterization neither diminishes the importance of the proceedings, nor reduces the general obligation of the judge to protect the fairness and reliability of the proceedings over which she presides. Like the trial and direct appeal, the postconviction process plays an important part in vindicating the constitutional rights of capital defendants. ${ }^{140}$ The Great Writ of Habeas Corpus is, after all, "a bulwark against convictions that violate fundamental fairness." ${ }^{141}$ Moreover, the habeas remedy comes into play only after the trial and direct appeal processes have failed to protect the defendant's constitutional rights. It would seem strange, therefore, to argue that postconviction judges have less of an obligation to supervise the conduct of the participants in their proceedings simply because the proceedings are collateral in nature.

Several benefits exist to having the courts perform the monitoring function. In some instances, for example, judicial monitoring can be more efficient than monitoring with an independent agency. This is especially true in cases where monitoring reveals a problem requiring judicial intervention, such as an order granting an extension of a filing deadline or an order removing counsel from the case. If an independent agency performs the monitoring, it must request these remedies from the judge, who then must

quotation omitted), disapproved on other grounds, People v. Crayton, 48 P.3d 1136, 1147 (Cal. 2002); McKenzie, 668 P.2d at 775 ("[T]he trial judge is vested with both the statutory and the inherent power to exercise reasonable control over all proceedings connected with the litigation before him."); People v. Shelley, 202 Cal. Rptr. 874, 880 (Cal. Ct. App. 1984) ("While we recognize that courts should exercise their power to remove defense counsel with great circumspection, they nevertheless retain the obligation to supervise the performance of defense counsel to ensure that adequate representation is provided.") (internal citations omitted); New York v. Claudio, 447 N.Y.S.2d 972, 981 (N.Y. App. Div. 1982) ("It is incumbent on a court to prevent incompetence."); see also Schwarzer, supra note 40, at $641 \mathrm{n} .42$ (citing cases).

Professor Richard Klein notes that " $[\mathrm{t}]$ he American Bar Association places similar demands on the trial judge in its Standards for Criminal Justice-Special Functions of the Trial Judge." Klein, supra note 40, at 540 (quoting ABA Standard 6-1.1). Under the current version of Standard 6-1.1(a):

The trial judge has the responsibility for safeguarding both the rights of the accused and the interests of the public in the administration of criminal justice. The adversary nature of the proceedings does not relieve the trial judge of the obligation of raising on his or her initiative, at all appropriate times and in an appropriate manner, matters which may significantly promote a just determination of the trial.

aba, Standards for Criminal Justice: Special Functions of the Trial Judge, Standard 6-1.1(a) (3d ed. 2000).

140. See supra notes 5-10 and accompanying text.

141. Engle v. Isaac, 456 U.S. 107, 126 (1982) (internal quotations omitted). 
review counsel's performance (thereby duplicating at least some of the agency's work) and assess whether the requested remedy is warranted. It is also more efficient in instances where the judge naturally would become aware of the problem before anyone else, such as when counsel fails to meet a filing deadline. Rather than waiting for an independent entity to discover the problem and seek a remedy, the judge can immediately assess the situation and determine whether a remedy is appropriate. Finally, judicial monitoring is more efficient when the court has ordered an evidentiary hearing on postconviction review. Because she presides over the hearing, the judge will always be present to observe, discover, and, if necessary, remedy any problems occurring during the hearing.

Additionally, as commentators have noted, judicial monitoring can encourage competent behavior from counsel. ${ }^{142}$ Through the process of monitoring, the judge conveys to counsel precisely what is expected of her during the postconviction proceedings. ${ }^{143}$ As Professor Barbara R. Levine explains:

For better or worse, judges draw the bottom line above which some lawyers may rise but below which few dare fall. Reasonable use of the judicial power to demand competent performance may be the single cheapest and most effective tool available. Judges are the individuals best situated to set and enforce performance standards. They have the knowledge to evaluate, the opportunity to observe, and the authority to intervene. ${ }^{144}$

Such encouragement can occur whether the monitoring is in the form of a face-to-face conference, ${ }^{145}$ or in the form of a written checklist. The key is for the judge to communicate to counsel what the court expects of counsel. ${ }^{146}$

142. Klein, supra note 40, at 580 ("Conducting a pretrial conference or requiring the attorney to file a pretrial worksheet with the court may prove to be an effective means of encouraging competent representation."); Levine, supra note 40, at 1441 ("If trial and appellate judges generally communicate higher performance expectations to lawyers, lawyers will feel obliged to meet those expectations."); Schwarzer, supra note 40, at 665 ("[A]s lawyers become cognizant of the trial judge's willingness to intervene to assure effective representation, their performance should improve, thus reducing the number of instances in which intervention by the judge is necessary.").

143. See Levine, supra note 40 , at 1441 ("If trial judges in specific cases inquire as to whether particular tasks have been completed, lawyers will feel compelled to complete those tasks.”).

144. Id. at 1442 .

145. See id. at 1443 (discussing utility of pretrial conference in shaping attorney behavior); Schwarzer, supra note 40, at 655 (arguing that counsel's “[p]articipation in a conference . . will almost certainly make [him] conscious of any gaps in his preparation").

146. See Levine, supra note 40, at 1441 (asking questions about counsel's preparation will remind counsel of tasks she must perform). Cf. Tague, supra note 40, at 161-62 (recommending that trial court "explain[] the attorney's obligations to counsel and to the defendant early in the proceedings" and then follow up "before trial ... [by] "ask[ing] the attorney to explain his preparation"). Arguably, this same 
One might argue that encouragement will not work in the capital context, as some lawyers would deliberately perform poorly in order to delay imposition of their client's death sentence. ${ }^{147}$ While diligent capital counsel surely seek to delay execution until all potentially meritorious claims are entertained by the courts, this hardly means that counsel will deliberately engage in unprofessional conduct. Moreover, as Professor Levine recognized, "attorneys, like anyone else, want to enhance their professional reputations, receive positive feedback for their efforts, and maintain good relationships with those in positions of authority."148 And in any event, deliberately engaging in actions designed to cause delay could be discouraged through judicially imposed sanctions, or referral to the state bar for disciplinary proceedings. ${ }^{149}$

Finally, judicial monitoring is beneficial as it can serve to remind the judges of the importance of competent performance, and the ingredients for such a performance. ${ }^{150}$ In other words, the process of monitoring might actually make judges more attuned to the presence of incompetent performance, and perhaps more receptive to remedying problems associated with such performance. ${ }^{151}$

Despite these benefits, observers have identified some problems with judicial monitoring that warrant scrutiny. To begin, some observers have argued that judicial monitoring, to the extent it requires judges to look for errors on behalf of the defendant, is inconsistent with the judicial role. ${ }^{152}$

encouragement could occur even if an independent entity performed the monitoring, because the substance of the questions themselves might cause counsel to take a hard look at her performance and do what is necessary to render competent performance.

147. See In re Sanders, 981 P.2d 1038, 1049 n.9 (Cal. 1999) (noting delay tactics by capital counsel).

148. Levine, supra note 40, at 1441.

149. See id. at 1441 (discussing how sanctions or referral to disciplinary authority could help improve attorney conduct).

150. Klein, supra note 40, at 582. Professor Richard Klein thought this benefit was "[p]erhaps the most significant advantage in instituting a system of pretrial conferencing...." Id.

151. See id. at 582 (suggesting that, after repeatedly emphasizing the necessity for adequate preparation and investigation, "the judge would find it most difficult to disregard [a claim that counsel is unprepared] and order the counsel to begin the trial").

152. See, e.g., Hodgkinson, supra note 99, at 56-57 (explaining that the "[j]udicial functions and adversarial functions are quite different, a fact we learn early in law school when we are called upon to present both sides of an issue in a legal memorandum and reach a neutral decision"); Levine, supra note 40, at 1433 (noting that trial judges engaged in monitoring "would have to avoid the temptation of getting overly involved in giving advice lest they compromise their own roles and counsel's"); $i d$. at n.606 (noting existence of "dispute" over "active judicial monitoring and intervention," and citing cases); Schwarzer, supra note 40, at 637 (acknowledging that judicial "[i]ntervention ... requires the judge to depart from his traditional neutral rule [sic]"). 
Judges, after all, are supposed to maintain a neutral posture and not act as the defendant's advocate. ${ }^{153}$ Similarly, if a judge does remain neutral, this could interfere with her ability to conduct an adequate review of counsel's performance. ${ }^{154}$ And, in an effort to avoid partiality, the judge might even limit herself to looking for only the most obvious errors, such as failure to file a timely habeas petition or failure to conduct any investigation whatsoever. Thus, as a practical matter, use of judicial monitoring might effectively limit the type of conduct that is monitored.

These concerns are not insubstantial, and monitoring, if designed improperly, could put judges in a position that compromises their neutrality, requires them to perform a task for which they are ill-suited, or perhaps even tempts them to limit their field of vision and search only for glaring errors. But, these concerns do not mean that judges should never perform the monitoring function. As Judge Schwarzer observed in the trial context, "the administration of justice is the judge's ultimate responsibility [and] he cannot be indifferent to events which diminish the quality of justice in his court." 155 Moreover, these concerns are reduced, if not eliminated, in the context of postconviction monitoring, because effective postconviction monitoring need not involve advocacy. As explained in more detail in subparts $\mathrm{B}$ and $\mathrm{C}$ below, the postconviction monitoring process focuses on searching for basic signs of actual and potential incompetence. Thus, rather than evaluating counsel's legal strategy or looking for potential claims, the judge ensures the smooth functioning of the postconviction process by watching for, and remedying, objectively identifiable conduct that could undermine the fairness of the

153. The Supreme Court recently reiterated this view of the judge's role in Pliler v. Ford, $124 \mathrm{~S}$. Ct. 2441 (2004), when it ruled that federal district courts are not constitutionally obligated to provide warnings to pro se habeas petitioners "explaining the details of federal habeas procedure" or the risks associated with dismissal of a petition containing both exhausted and unexhausted claims. Id. at 2446. Judges, the Court explained, "have no obligation to act as counsel or paralegal to pro se litigants." Id. Moreover, "[r]equiring district courts to advise a pro se litigant in such a manner would undermine the district judges' role as impartial decisionmakers." Id.

154. See Smith v. Robbins, 528 U.S. 259, 298-99 (2000) (Souter, J., dissenting) (arguing against the Wende procedure because courts are neutral and do not review cases with "partisan scrutiny"); Hodgkinson, supra note 99, at 56 (arguing that requirement for neutrality interferes with ability to perform as an advocate).

155. Schwarzer, supra note 40 , at 638 . Even opponents of judicial intervention perceive the need for judicial intervention in order to protect the right to counsel. For example, in a recent article, Professor Michael Pinard argued against judicial intervention at criminal trials on the ground that such intervention undermines the judge's role and improperly influences the jury. Michael Pinard, Limitations on Judicial Activism in Criminal Trials, 33 Conn. L. Rev. 243, 251-78 (2000). Professor Pinard nevertheless recognized that judges should intervene to protect the defendant's right to a fair trial, which would include instances in which counsel performed inadequately. Id. at 278, 283-87. 
proceeding, such as obviously inadequate preparation, and conduct that assuredly will do so, such as failure to file a timely postconviction petition. ${ }^{156}$ In short, postconviction monitoring requires no more from the judge than she is already obligated to provide, and, thus, should not threaten the judge's neutrality.

Similar to the neutrality issue is the concern that judicial monitoring might somehow influence or taint the judge's view of the case. ${ }^{157}$ The concern is that the judge might learn something through the monitoring process that causes her to prejudge the case. ${ }^{158}$ But again, a properly structured monitoring process can avoid, or at least minimize, this problem. ${ }^{159}$ Proper postconviction monitoring will not provide the judge with an opportunity to "preview" the merits of the case, as it will not reveal an attorney's strategic choices or the attorney's view of the strength of the case. Instead, monitoring simply allows the judge to assess the lawyer's level of preparation and compliance with filing requirements.

But, even if monitoring does reveal information that might taint a judge's view of the case, this would not render monitoring constitutionally infirm, as the possibility of prejudice would be outweighed by the need to ensure that counsel is performing adequately. ${ }^{160}$ The Anders procedure provides a good example of balancing the risk of prejudice against the need to protect constitutional rights. Recall that under the Anders procedure, appointed appellate counsel moves to withdraw on the ground that the case is meritless, while simultaneously filing a brief raising arguable issues for appeal. Even though the mere filing of a withdrawal motion and an Anders brief is enough

156. See Schwarzer, supra note 40, at 650 (monitoring does not require trial judge to "evaluate the relative efficacy of trial tactics or to determine whether counsel's performance should receive a passing grade[,]" but rather requires the judge "to remedy observed deficiencies before it is too late").

157. E.g., Levine, supra note 40, at 1433 (noting that, with pretrial conferences, "[1]awyers would rightly fear . . . affecting the judge's impartiality at trial"); Tague, supra note 40, at 163 (noting that "attorneys ... would justifiably fear giving information to the judge because it might affect that judge's rulings at trial and his evaluation of the testimony or the defendant's guilt").

158. E.g., Levine, supra note 40, at 1433; Tague, supra note 40, at 163.

159. In the trial context, Professor Tague suggests having another judge conduct the pretrial monitoring conference. Tague, supra note 40, at 164 . He recognizes, however, that such a "solution would be cumbersome in jurisdictions where the dockets are already overcrowded." Id.

160. In People v. Marsden, 465 P.2d 44, 49 (Cal. 1970), the California Supreme Court reached a similar conclusion in the context of a trial court's duty to inquire into the basis for a defendant's request for substitute counsel. There, the trial counsel declined to "hear the defendant's basis for dissatisfaction with counsel," citing a "concern that defendant's evidence might prejudice" the judge. Id. at 49 (internal quotation omitted). The California Supreme Court rejected this concern as "lack[ing] substance." Id. As the court reasoned, "[i]f there were some remote prejudicial effect, it would be outweighed by the importance of replacing an incompetent attorney." Id. 
to potentially influence the appellate court's view of the case, ${ }^{161}$ the Court suggested this procedure as a way of protecting the constitutional right to counsel on direct appeal. ${ }^{162}$ The possibility of prejudice is outweighed by the need to ensure that counsel acts as an advocate on direct review.

Another frequently cited concern about monitoring is the potential interference with client confidentiality. This concern, of course, is not peculiar to judicial monitoring, but instead arises no matter who performs the monitoring function. While concerns about breaching client confidentiality surely exist, such concerns, like the concerns with neutrality and impartiality, can be addressed through proper structuring of the monitoring process. ${ }^{163}$ The monitoring entity, whether it is a court or an independent agency, does not need confidential information in order to determine whether counsel has taken adequate steps to prepare a solid postconviction petition, or whether counsel is performing adequately during an evidentiary hearing. It does not need to know, for example, counsel's strategy for investigating the case or counsel's thoughts on the merits of any of the claims in the case. Instead, as detailed in subpart $\mathrm{C}$ below, the monitoring entity needs information such as the basic steps counsel has taken to investigate the case, the number of hours counsel has worked on the case, and the timeliness of the postconviction petition. ${ }^{164}$

Another potential problem is that judges might simply be too busy to perform a monitoring function. ${ }^{165}$ This would constitutionally disable judges from performing the monitoring function, for a superficial review would not adequately safeguard the right to effective assistance of capital postconviction counsel. ${ }^{166}$ There are, however, possible ways to remedy this problem. First,

161. See State v. McKenney, 568 P.2d 1213, 1214 (Idaho 1977) (noting that request to withdraw on grounds of lack of merit "cannot but result in prejudice").

162. See Anders v. California, 386 U.S. 738, 745 (1967). The Anders procedure is not without its critics. See, e.g., Duggan \& Moeller, supra note 114, at 92-106 (discussing weaknesses of Anders procedure); Hodgkinson, supra note 99, at 56 (arguing that "[a] no-merit brief system allows a real breakdown of the adversary system").

163. See Klein, supra note 40, at 583 (responding to confidentiality concerns by explaining that monitoring need not require "the trial court judge to scrutinize confidences, strategies or tactics"); Levine, supra note 40, at 1434-35 (suggesting pretrial conference focusing on "preparation of all participants, [so that] conferences become a means of improving the efficiency and fairness of the entire criminal process").

164. In the trial context, Professor Richard Klein argued that "the [trial] court's focus should be on whether the lawyer has devoted the time necessary to prepare and investigate the client's case properly." Klein, supra note 40 , at 583.

165. Levine, supra note 40, at 1443 ("Allocating time for pretrial conferences in jurisdictions with overcrowded dockets is no easy task."); $i d$. at 1434; see also Klein, supra note 40, at 581 ("Beacause ... conferences require time, they are likely to meet resistance in any already overburdened system.").

166. Cf. Anders, 386 U.S. at $741-43$ (finding that conclusory "no merits" letter filed by counsel was insufficient to protect right to counsel on direct appeal as it provided no assurance that counsel acted as an 
if a judge is too busy to conduct the monitoring, she could delegate the monitoring function to a different judge. ${ }^{167}$ Or, if all judges are overburdened, the government could reduce the workload of postconviction judges, thereby enabling them to perform the monitoring function. ${ }^{168}$ But if neither of these options is possible (or palatable), then the government may not use judicial monitoring, and instead must establish an independent agency to conduct the monitoring.

Most damning is the criticism that some judges lack the ability or motivation to perform the monitoring function in a constitutionally sufficient manner. In terms of ability, Professor Levine reminds us that judges are only human: "[J]udges are just lawyers in robes, often elected as much on name recognition as merit and subject to many of the same pressures as the lawyers before them.... [S] ome, not having been stellar practitioners themselves, may simply lack high standards to set." "169 And, in terms of motivation, Professor Levine observes: "Some [judges] may . . . identify with friends and former colleagues and be disinclined to assume a regulatory role."

Particularly revealing is Professor Bright's research on the quality of state judges in Texas - and his conclusion that these judges have not adequately protected the constitutional rights of capital inmates. ${ }^{171}$ He argues that Texas judges, who are elected to the bench, tend to steer clear of anything that will make them appear "soft on crime," as this dampens their chances of reelection. ${ }^{172}$ Professor Bright also argues that Texas state judges at all levels

advocate in representing defendant).

167. Klein, supra note 40, at 581-82. Professor Richard Klein notes that this would also help relieve the concern regarding the judge's impartiality. Id. See also Tague, supra note 40, at 164 (arguing that having "a different judge . . s speak with the attorney at the conference" might "avoid influencing the trial judge").

168. See Levine, supra note 40, at 1443 ("[C]ontrolling the size of judicial workloads may be as important to improved defense representation as controlling the size of attorneys' caseloads.").

169. Id. at $1442-43$.

170. $I d$.

171. Stephen B. Bright, Elected Judges and the Death Penalty in Texas: Why Full Habeas Corpus Review by Independent Federal Judges Is Indispensable to Protecting Constitutional Rights, 78 TEX. L. Rev. 1805, 1836-37 (2000) [hereinafter Bright, Elected Judges].

172. Id. at 1808, 1826-32. See also Stephen B. Bright \& Pat J. Keenan, Judges and the Politics of Death: Deciding Between the Bill of Rights and the Next Election in Capital Cases, 75 B.U. L. Rev. 759 , 760-66 (1995); Liebman et al., supra note 1, Part II, at 171. According to Professor Bright:

What is happening in Texas is not limited to that state. . . Judges are elected in thirty-two of the thirty-eight states that have the death penalty. The removal of judges perceived as "soft on crime" has made it clear to those remaining on the bench that upholding the law in capital cases comes at their own peril.

Bright, Elected Judges, supra note 171, at 1808. 
are largely unconcerned with the competence of capital counsel. With respect to appointing capital postconviction counsel, Professor Bright explains:

During a four-year period when it was responsible for appointing lawyers to represent the condemned in post-conviction review, the Court of Criminal Appeals repeatedly appointed lawyers who were incapable of preparing petitions and filing them on time. It then punished the inmates for the incompetence of their lawyers by denying them relief over dissents that characterized the court's review as a "farce," "travesty," and "charade." 173

[T] he Court of Criminal Appeals not only appointed its cronies, the inexperienced, and the incompetent to represent those facing death; it also discouraged capable lawyers from taking capital cases and devoting the time necessary to do an adequate job by limiting compensation to the lawyers appointed and denying necessary expert and investigative assistance. ${ }^{174}$

A poll of state judges in Texas revealed that some lawyers in Texas are appointed as "a reward for campaign contributions," while others are appointed because of a "reputation for moving cases quickly, regardless of the quality of the defense." 175 Moreover, campaign contributions affect more than just appointments. In a recent survey, "forty-eight percent [of judges polled] admitted that campaign contributions are a 'very' or 'fairly' influential factor in their courtroom decisions." 176

Admittedly, the criticism about judicial bias and inability is a bit more difficult to deflect. Judges who are more interested in re-election than administering justice are unlikely to perform a sufficiently rigorous or complete review of postconviction counsel's performance. And, we ought not expect much in terms of monitoring from a judge who has difficulty appointing competent counsel in the first place. ${ }^{177}$ At a minimum, Professor Bright's research raises some doubt about the wisdom of placing the monitoring function in the hands of some judges, especially those who are

173. Bright, Elected Judges, supra note 171, at 1806.

174. Id. at 1824 .

175. Id. at 1831. Professor Bright further revealed:

Once elected, many Texas judges behave as other politicians do, doling out favors and appointments to their supporters. In a survey of Texas judges, over half said that judges they knew based their appointments to defend indigent defendants in part on whether the attorneys were political supporters or had contributed to the judge's political campaign. Id. at 1830

176. Id. at 1831 .

177. Professor Bright argues that the Texas Court of Criminal Appeals "has ... used strict adherence to the Texas post-conviction statute to avoid correcting its own mistakes on direct appeal." Id. at 1823 . It is not difficult to believe, therefore, that some judges might avoid second-guessing the decisions of postconviction counsel. 
elected. ${ }^{178}$ His research also suggests that the use of judicial monitoring in Texas would not satisfy the meaningfulness requirement. The same would be true, of course, in any state in which the judiciary has consistently and repeatedly demonstrated disregard for the constitutional rights of capital inmates.

While problems with the judiciary assuredly exist in some states, lack of confidence in all judges across the country is unwarranted at this point. Moreover, the possibility that some judges might act with bias when monitoring the performance of postconviction counsel does not render the use of judicial monitoring constitutionally intolerable. ${ }^{179}$ Thus, judicial monitoring is not completely off the table as a means of meeting the constitutional obligation to conduct a meaningful during-performance review of postconviction counsel's conduct. While judicial monitoring would be constitutionally inappropriate in states, such as Texas, where the judges across the state have consistently ignored their obligations to administer justice and ensure the integrity of their proceedings, such monitoring would be appropriate in states where the judges as a whole have demonstrated no such tendencies. When establishing a system of monitoring, each state must take a hard look at the performance of its judiciary and determine whether the monitoring function can safely be placed there, or whether it ought to be placed with an independent agency.

\section{Monitoring by an Independent Agency}

Although the states have not yet moved in this direction, the ABA has long believed that an entity independent of the courts would perform the monitoring function in a more satisfactory, and successful, manner. For at least the last fifteen years, the ABA has recommended the use of an

178. Professor Andrew Hammel raises this same point in his recent article discussing the viability of this author's proposal for during-performance reviews. Hammel, supra note 9, at 388 (contending that in states where "courts have shown no hesitancy to affirm clearly incompetent representation, ... it is certainly questionable whether a high court or appointed commission would recognize a truly exacting standard of competent performance - and even whether it would risk delaying an execution to remedy a violation of a proper standard").

179. Cf. Martin v. Hunter's Lessee, 14 U.S. (1 Wheat) 304, 344 (1816) ("It is always a doubtful course, to argue against the use or existence of a power, from the possibility of its abuse."). The possibility that some judges might act with bias does, however, raise the question of how to remedy instances of biased monitoring. This question, along with the question of how to remedy inadequate monitoring (or a complete failure to monitor), is important and merits detailed consideration. Nevertheless, this Article explores how to structure a meaningful system of monitoring, and leaves for another day the question of how to remedy biased, inadequate, and nonexistent monitoring. 
independent agency not only for appointing capital counsel at all levels of review, but also for monitoring the performance of such counsel. ${ }^{180}$ As the ABA explains, relying on an independent entity for "training, assigning, and monitoring capital defense lawyers" is necessary to "ensure that the capital defense function remains free from political influence." "181

According to its Guidelines for the Appointment and Performance of Defense Counsel in Death Penalty Cases (ABA Guidelines), ${ }^{182}$ the monitoring entity may be either a "defender organization" or an "Independent Authority." comprised of individuals trained in representing capital inmates. ${ }^{184}$ The basic difference between the two would be that the defender organization, in addition to monitoring counsel, could also provide representation for capital counsel, while the Independent Authority could not.

To prevent conflicts of interest, the ABA Guidelines prohibit the defender organization from monitoring its own performance as an agency, or the performance of individuals in its office who have been appointed to represent capital inmates. ${ }^{185}$ In these situations, the Independent Authority must

180. See ABA Recommendations, supra note 31, at 254-55 ("The appointing authority shall . . periodically review the rosters, monitor the performance of all attorneys appointed, and withdraw certification from any attorney who ... fails to meet high performance standards in a case to which the attorney is appointed ...."); 1989 ABA GuIDELINES, supra note 35, at Guideline 7.1 ("The appointing authority should monitor the performance of assigned counsel to ensure that the client is receiving quality representation."); 2003 ABA Guidelines, supra note 2, at Guideline 7.1, at 970 ("The Responsible Agency should monitor the performance of all defense counsel to ensure that the client is receiving high quality legal representation.").

181. 2003 ABA Guidelines, supra note 2, at Guideline 3.1, at 948.

182. 2003 ABA Guidelines, supra note 2. The 2003 ABA Guidelines apply at "all stages of every case in which the jurisdiction may be entitled to seek the death penalty, including initial and ongoing investigation, pretrial proceedings, trial, post-conviction review, clemency proceedings and any connected litigation." Id. at Guideline 1.1, at 919.

183. $I d$. at Guideline 3.1, at 944-45. The entity that performs the monitoring function also recruits, appoints, and trains capital counsel. See id. at Guideline 3.1, at 944-48.

184. The Independent Authority must be "run by defense attorneys with demonstrated knowledge and expertise in capital representation. Id. at Guideline 3.1, at 945. The defender organization must be either "a jurisdiction-wide capital trial office" or a "jurisdiction-wide capital appellate and/or post-conviction defender office." Id. at Guideline 3.1, at 944. It may "rely[] on staff attorneys, members of the private bar or both to provide representation in death penalty cases." Id. at Guideline, 3.1, at 944. Presumably, if the jurisdiction had both a capital trial unit and a capital postconviction unit, the former unit would handle the appointment and monitoring of trial counsel, and the latter would handle the appointment and monitoring of postconviction counsel.

185. Id. at Guideline 3.1, at 949. The 2003 ABA Guidelines prohibit defender organizations from engaging in any activity that creates a conflict of interest, and monitoring one of its own employees is but one example. See id. (providing examples of conflicts of interest). 
perform the monitoring function. ${ }^{186}$ Similarly, to avoid conflicts of interests, "attorneys who hold formal roles [with the Independent Authority] . . . should ${ }^{187}$ be ineligible to represent defendants in capital cases within the jurisdiction during their term of service." 188

As structured by the ABA, use of an independent agency to monitor the performance of capital postconviction counsel would adequately protect the right to effective assistance of counsel, and, thus, would satisfy the meaningfulness requirement. Independent agencies, such as those recommended above, would be comprised of individuals who not only possess expertise in the field of capital punishment litigation, but who also, as members of a defender organization or as defense practitioners, likely would have a commitment to capital defendants and a self-imposed obligation to unearth incompetent performance. And, unlike judges, individual agencies have no obligation to remain neutral. Instead, they have as their sole obligation the appointment, training, and monitoring of capital postconviction counsel. According to the ABA Guidelines, for example, the agency's "paramount objective [is to] protect[] the rights and interests of the defendant." 189 Obviously, this one-sided allegiance benefits the capital inmate, as the agency is not only free, but also appears obligated to rigorously review counsel's performance for signs that counsel is, or may be, performing incompetently. ${ }^{190}$

186. Id. Thus, for all practical purposes, if a state chooses to use a defender organization for monitoring, it must also establish an Independent Authority. See id. (noting that the recommendation "contemplates the existence of an 'Independent Authority,' which will at a minimum deal with conflicts such as these").

187. The word "should" is mandatory under the 2003 ABA Guidelines. Id. at Guideline 1.1, at 919.

188. Id. at Guideline 3.1, at 945 ; see id. at Guideline 3.1, at 949.

189. Id. at Guideline 7.1, at 974; see also id. at Guideline 7.1, at 973 (independent monitoring entity has "duty to ensure that high quality legal assistance is afforded to indigent capital defendants"); $i d$. at Guideline 3.1, at 948 (independent monitoring entity is "wholly devoted to fostering high quality legal defense representation").

190. The commentary to the 2003 ABA Guidelines makes clear that the independent agency is not limited to simply responding to complaints about counsel's performance. Instead, "an effective attorneymonitoring program in death penalty matters should go considerably beyond these activities. The performance of each assigned lawyer should be subject to systematic review based upon publicized standards and procedures." Id. at Guideline 7.1, at 973 (emphasis added). Moreover, the agency has an obligation to "take appropriate action in the event of any substandard performance," which further suggests an obligation to rigorously review counsel's performance. Id. at Guideline 7.1, at 974 (emphasis added). These recommendations are commendably rigorous, and would go a long way in improving the delivery of effective assistance. But, as explained below, they exceed the demands of the meaningfulness requirement and, thus, would not be required to render the monitoring process constitutionally meaningful. 
Moreover, use of individual agencies to perform the monitoring function solves many of the problems associated with judicial monitoring. As explained above, there is no neutrality issue with independent agencies. Similarly, monitoring by an independent agency would not threaten the court's impartiality. The agency, rather than the court, would gather the relevant information regarding counsel's performance and assess the relative quality of that performance. ${ }^{191}$ The information need not be shared with the court unless the monitoring entity concluded that counsel's performance warranted a judicial remedy, such as extension of a filing deadline or removal of counsel. Even in that situation, the information shared with the judge would normally involve counsel's alleged failings and the need for a remedy, rather than any particular weakness of the capital inmate's case. Finally, use of independent agencies should not give rise to allegations of lack of ability or lack of motivation, for, as described above, members of the independent agency must possess expertise in capital punishment jurisprudence and would very likely feel an obligation to thoroughly search for problems with counsel's performance. ${ }^{192}$

Although use of independent monitoring entities would satisfy the meaningfulness requirement, such entities are not a panacea. As mentioned above, use of such entities creates a potential for inefficiency. If monitoring reveals a problem that warrants a judicial remedy, then the judge, in determining whether a remedy is appropriate, must review and evaluate the very same evidence already reviewed and evaluated by the agency. This duplication of work prolongs the monitoring process (and perhaps the postconviction process as well), and could well explain why the states that monitor the performance of capital counsel, whether at trial and direct appeal, or on postconviction review, have almost uniformly opted for judicial monitoring. ${ }^{193}$

This potential for inefficiency cannot be eliminated from a monitoring system that uses independent agencies to perform the monitoring function, because no effective monitoring system can exist without the participation of

191. See, e.g., id. at Guideline 7.1, at 973-74 (discussing the monitoring function).

192. See id. at Guideline 3.1, at 944-45. To the extent there is bias, then, it would seem to be in favor of the defendant, rather than against her. But see Hammel, supra note 9, at 388 (arguing that in some death penalty jurisdictions "it is certainly questionable whether a high court or appointed commission would recognize a truly exacting standard of competent performance — and even whether it would risk delaying an execution to remedy a violation of a proper standard"). While such bias presents no constitutional obstacle to the use of independent agencies as the monitoring entity, it might well be enough to persuade the states to select courts to perform the monitoring function.

193. See supra note 126 and accompanying text. 
the judiciary. As will be discussed in detail in Part D below, there are times when counsel's poor performance warrants a remedy only the courts can provide, such as extending filing deadlines, removing and replacing counsel, or sanctioning counsel. ${ }^{194}$ Thus, even if a state uses an independent agency to monitor counsel's performance, it must permit access to the courts to remedy problems identified during the monitoring process. Without such access, no system of monitoring would be constitutionally meaningful.

Additionally, because courts must be involved at least at the remedy phase of the monitoring process, use of independent agencies during the monitoring phase will not completely remove the potential for judicial bias from the monitoring process. While judges will not be involved in gathering the information regarding counsel's performance, they inevitably will be involved in evaluating whether the performance warrants a judicial remedy. It is in this capacity where judicial bias becomes possible. It is not unreasonable to assume that a judge who acts with bias (consciously or unconsciously) during the monitoring phase is just as likely to do so during the remedy phase. In short, no system of monitoring can completely eradicate the possibility that some judges will make ill-motivated decisions. ${ }^{195}$

As demonstrated above, there are benefits and drawbacks with using either the courts or an independent entity to monitor counsel's performance. Nevertheless, either the courts (provided they have time and there is no evidence of routine disregard for the constitutional rights of capital inmates) or an independent entity could perform the monitoring function in a manner that would satisfy the meaningfulness requirement. Thus, each state remains free to select the entity that suits the state's particular needs. Between the two, however, monitoring by an independent entity is the better choice. Independent entities, unburdened by a need to remain neutral and charged with the "paramount obligation of protecting the rights and interests of the defendant," $" 196$ are more likely than courts to spot potential problems with postconviction counsel's performance.

Of course, even better than using an independent entity would be to use both the courts and independent entities, charging each entity with the responsibility to monitor counsel's performance. Doing so would likely

194. See infra notes $337-63$ and accompanying text.

195. Again, the possibility that some judges might act with bias when determining whether to grant a remedy for incompetent performance raises the question of how to remedy failures by the monitoring entity. As explained earlier, see supra note 178 and accompanying text, questions relating to biased, inadequate, and nonexistent monitoring, while important, are not explored here.

196. 2003 ABA Guidelines, supra note 2, at Guideline 7.1, at 974. 
improve monitoring, as it would emphasize the strengths of each entity while eliminating (or alleviating) some of the weaknesses. For example, because judges are concerned about neutrality and pressed for time, they could be assigned the duty of searching for and remedying obvious problems, such as failure to file a timely petition, or incompetent handling of an evidentiary hearing. This would, in turn, enhance efficiency, thereby solving a problem associated with using only independent entities to monitor counsel's performance. Independent entities, comprised of experts who are duty-bound to ferret out problems with capital representation, could perform the more detail-oriented aspects of the review process, such as assessing the adequacy of counsel's preparation to file a meaningful petition. Though not demanded by the meaningfulness requirement, such combination monitoring would be an extremely effective way to conduct the during-performance review.

\section{B. The Monitoring Standard}

No monitoring entity can begin to evaluate the sufficiency of counsel's performance without the guidance of a monitoring standard, as it dictates the scope of the monitoring obligation. In the context of conducting a postperformance review of trial and appellate counsel's performance, courts measure constitutional effectiveness using the standard enunciated in Strickland $v$. Washington. ${ }^{197}$ The question addressed in this section is whether the standard ought to be different in the context of during-performance reviews, given that the review takes place during the actual proceeding, rather than after it. ${ }^{198}$ In other words, should the monitoring standard only target

197. Strickland v. Washington, 466 U.S. 668 (1984).

198. Strickland has long been criticized for failing to adequately protect the constitutional rights to trial and appellate counsel, as it fails to remedy all but the most egregious errors. See, e.g., Louis D. Bilionis \& Richard A. Rosen, Lawyers, Arbitrariness, and the Eighth Amendment, 75 Tex. L. Rev. 1301, 1304-06 \& nn.13-17 (1997) (listing sources "decry[ing] the sorry state of capital lawyering and the failure of Strickland and the new habeas to do anything about it"); Dripps, supra note 31, at 281 (noting that although numerous ineffectiveness claims are raised each year, "very few of these cases result in reversal"); $i d$. at 280-81 (noting that waiver of "claim[s] . . that would have been . . clear winner[s] . . is about the only thing that ... amount[s] to ineffective assistance"). Professor Dripps goes further than just criticizing the application of the Strickland standard; he challenges the efficacy of post-performance reviews in general. As he argues: "Ultimately, no ex post standard can remedy the real defects of the defense function. In the first place, ex post review is simply incapable of detecting ineffective assistance. In the second place, ex post review can remedy ineffective assistance only at the expense of the finality interest." Dripps, supra note 31, at 285. As an alternative, Professor Dripps argues for an "ex ante parity standard," with courts examining counsel competence before trial to ensure that "the litigation capability of the adversaries, independent of the merits of their respective cases, is more-or-less evenly matched." Id. at 293.

This Article does not address the relative merits of Strickland as an effectiveness standard. Instead, 
conduct that satisfies the Strickland definition of constitutional ineffectiveness ${ }^{199}$ or should it target a wider swath of conduct—specifically, conduct (or circumstances) that threatens or undermines the delivery of effective assistance. The answer, of course, depends on which standard better protects the right to monitoring and, in turn, the right to effective assistance of counsel, without unduly burdening the government.

Strickland measures constitutional ineffectiveness using two prongs - deficient performance and prejudice — both of which are designed to ensure "that a defendant has the assistance necessary to justify reliance on the outcome of the proceeding." ${ }^{200}$ Under the deficient performance prong, the defendant must demonstrate that counsel did not act as "a reasonably competent attorney," which is to say that counsel's performance did not fall "within the range of competence demanded of attorneys in criminal cases.".201 She must also show prejudice, which is defined as "a reasonable probability that, but for counsel's unprofessional errors, the result of the proceeding

recognizing that it is the standard the Court has enunciated for evaluating counsel performance, the Article assumes for the sake of argument that Strickland is appropriate for post-performance reviews of trial and appellate counsel, and seeks only to determine whether it would also be appropriate for during-performance reviews of postconviction counsel.

199. Congress appears to adopt Strickland as the monitoring standard, as it allows removal of postconviction counsel for "ineffectiveness" or "incompetence." 28 U.S.C. § 2261(e) (2000).

200. Strickland, 466 U.S. at 692 . The Strickland standard applies only to constitutional grants of counsel. Wainwright v. Torna, 455 U.S. 586 (1982). Thus, it has been used to evaluate the performance of trial and direct appeal counsel, but not the performance of postconviction counsel. See Coleman v. Thompson, 501 U.S. 722, 752 (1991).

201. Strickland, 466 U.S. at 687 . The Court declined to identify a "particular set of . . rules for counsel's conduct," reasoning that "[a]ny such set of rules would interfere with the constitutionally protected independence of counsel and restrict the wide latitude counsel must have in making tactical decisions." Id. at 688-89. Professor Dripps agrees with the Court's refusal to create a performance checklist. As he explains:

Strickland rightly recognized that no check-list adequately measures effective representation. A savvy defense lawyer might be able to obtain the best possible results for her client with a single telephone call. A lawyer who dutifully interviewed witnesses and filed motions, without thinking about the defenses the witnesses' stories suggest or how to support the motions made, might well get the client more time than he deserved.

Dripps, supra note 31, at 284. But see William S. Geimer, A Decade of Strickland's Tin Horn: Doctrinal and Practical Undermining of the Right to Counsel, 4 WM. \& MARY BILl RTs. J. 91, 157 (1995-1996) (criticizing "Strickland's refusal to acknowledge that there are specific, very basic, identifiable actions that must be taken in every case in order to render reasonably effective assistance"). 
would have been different." ${ }^{202}$ In other words, she must show that counsel's deficient performance affected the reliability of the criminal proceeding. ${ }^{203}$

At first blush, the Strickland standard might appear sufficient as a monitoring standard, for it seeks to accommodate the interests of both the capital defendant and the government. ${ }^{204}$ Upon closer examination, however, it is clear that application of Strickland to evaluate the on-going conduct of capital postconviction counsel is inappropriate, as it is not only too costly for the government, but it also fails to adequately ensure the delivery of competent performance. This is because Strickland was designed to evaluate claims of ineffective assistance in the particular context of post-performance reviews - a context much different from that used during-performance reviews. Post-performance reviews take place in a separate proceeding after the challenged conduct has occurred. As such, they necessarily involve a backward-looking evaluation of counsel's conduct to determine whether counsel has actually performed competently. And, if counsel has failed to do

202. Strickland, 466 U.S. at 694 . This can be difficult to do, largely because proving prejudice is an almost impossible task. As Professor Bright explains:

[C]ompetent legal assistance can make a difference in the outcome which may not be detectable by reviewing courts.

A lawyer may muddle through a case with little or no preparation, but it is impossible to determine how the case might have been handled differently if he had investigated and prepared. Other difficulties may be even more difficult to detect. Rapport with the client and the family may lead to cooperation and the disclosure of compelling mitigating evidence that might not be found by a less skillful attorney. Good negotiating skills may bring about a plea offer to resolve the case with a sentence less than death, and a good relationship with the client may result in acceptance of an offer that might otherwise be rejected.

The prejudice standard is particularly inappropriate for application to deficient representation at the penalty phase of a capital case. It is impossible for reviewing courts to assess the difference that investigation into mitigating circumstances and the effective presentation of mitigating evidence might make on a jury's sentencing decision.

Stephen B. Bright, Counsel for the Poor: The Death Sentence Not for the Worst Crime but for the Worst Lawyer, 103 YALE L.J. 1835, 1864 (1994). See also, e.g., Dripps, supra note 31, at 278 (noting that, “[o]n appeal, the defendant's guilt appears certain even if trial counsel botched the investigation; only a heroic second-effort by appellate counsel can challenge that impression"); Geimer, supra note 201, at 122 (asserting that while the adequacy of counsel's performance can "[w] ith some degree of difficulty . . . be evaluated in hindsight[,] [p]rejudice from inadequate performance, especially as to sentencing, is not similarly amenable to second guessing"); $i d$. at 103 (discussing how application of prejudice prong likely would have changed the result in Powell v. Alabama, 287 U.S. 45 (1932)). For a thorough critique of the prejudice prong, see Geimer, supra note 201, at 131-38 (contending that Strickland prejudice prong improperly places burden of error on defendant's shoulders).

203. Strickland, 466 U.S. at 687.

204. Seeid. at 689-696 (discussing defendant's interest in fair proceeding and government's interests in avoiding delay and achieving finality). 
so, the defendant is entitled to a new proceeding. In short, the postperformance review process protects the right to effective assistance by correcting past instances of incompetence, and the Strickland standard, which targets only those unreasonable errors that actually undermined the particular proceeding, was designed with this purpose in mind. ${ }^{205}$

During-performance reviews, on the other hand, are not backward-looking exercises involving the use of hindsight. Instead, such reviews are forwardlooking endeavors intended to ensure that counsel is performing competently during the postconviction proceeding. ${ }^{206}$ The Strickland corrective standard - that is, one that searches only for instances of actual constitutional ineffectiveness - would require the monitoring entity to look over counsel's shoulder, watching and evaluating her every move for instances of actual ineffectiveness. This is an extremely costly endeavor, as the government would have to establish a monitoring entity equipped with the resources to shadow counsel in each capital postconviction case. ${ }^{207}$ It also compromises the attorney-client relationship. ${ }^{208}$

While one might consider reducing the monitoring obligation to require the monitoring entity to search only for obvious signs of constitutional error, even this narrower search for constitutional error would require fairly significant resources. For example, if the monitoring entity detected that counsel had completely failed to conduct an investigation into the circumstances surrounding the underlying crime (an obvious, and unreasonable, error), the monitoring entity could seek a remedy for this failure only if it constituted actual ineffectiveness under Strickland - meaning that the failure prejudiced the defendant. To determine this, the monitoring entity would have to conduct its own investigation in search of meritorious claims - a laborious task to say the least.

But, it is not just the costs associated with Strickland's corrective standard that make it untenable in the during-performing context; rather, it is

205. Strickland, 466 U.S. at 691-92.

206. See Fla. Stat. Ann. § 27.711(12) (West Supp. 2003) ("The court shall monitor the performance of assigned counsel to ensure that the capital defendant is receiving quality representation.") (emphasis added); 2003 ABA Guidelines, supra note 2, at Guideline 7.1, at 970 (noting that the monitoring entity "should monitor the performance of all defense counsel to ensure that the client is receiving high quality legal representation") (emphasis added).

207. Because of neutrality concerns, judges certainly could not perform such in-depth monitoring. See supra notes 150-54 and accompanying text.

208. See 2003 ABA Guidelines, supra note 2, at Guideline 7.1, at 973 (noting that monitoring entity "should not attempt to micro-manage counsel's work," as it could interfere with the "attorney-client relationship"). 
that Strickland's corrective standard fails to accurately reflect (and therefore fails to achieve) the purpose of the monitoring process, which is, to the extent practicable, to prevent ineffective assistance from occurring in the first place. Judge Schwarzer recognized this in the context of monitoring trial counsel. As he explained in his oft-cited article, the purpose of trial court monitoring is not to determine whether counsel's performance "satisfies one of the minimum standards formulated by the appellate courts or whether a party is being denied effective representation. Instead, his function is to remedy observed deficiencies before it is too late ...."209 In other words, monitoring represents an attempt "to provide preventive relief." 110 As such, to satisfy the meaningfulness requirement, the government must utilize a standard that is preventive, not corrective, in nature. This means that, rather than merely targeting instances of actual ineffective assistance, as Strickland does, the standard must also target conduct that threatens the delivery of effective assistance. ${ }^{211}$

Both Florida, which expressly requires capital postconviction monitoring, and the ABA, which recommends it, have adopted preventive monitoring standards that target this wider swath of conduct. Florida, for example, allows "any interested person [to] advise the court of any circumstances that could affect the quality of representation, including, but not limited to, . . . misconduct, failure to meet continuing legal education requirements, ... or failure to file appropriate motions in a timely manner." ${ }^{12}$ The ABA goes even

209. Schwarzer, supra note 40, at 650 (emphasis added). See also Levine, supra note 40, at 1430 ("To prevent mistakes from causing damage in the first place, performance must be monitored while it is occurring.").

210. Id. at 665 (emphasis added); id. at 656 ("Serious deficiencies are likely to be disclosed at [pretrial monitoring conferences], affording the trial judge an opportunity to take preventive actions."); see also Bazelon, supra note 131, at $832 \mathrm{n} .94$ (asserting that monitoring of trial counsel using "pretrial worksheets" can "aid in preventing ineffective assistance from occurring"); Klein, supra note 40, at 580 (commenting that judicial monitoring of trial counsel, conducted either through "a pretrial conference" or "pretrial worksheet . . . may prove to be an effective means of encouraging competent representation") (emphasis added); Tague, supra note 40, at 112 (recommending judicial monitoring of trial counsel in order to "prevent ineffectiveness before the verdict is announced") (emphasis added).

211. See Schwarzer, supra note 40, at 659 ("[W] here counsel's inadequacy appears to be so serious that it creates a risk of ineffective representation, the court should advise the client of that fact and of the right to change counsel.") (emphasis added); id. ("Even where the defendant does not consent [to removal], the court may, where gross incompetence has been demonstrated, bar counsel and appoint substitute counsel or require defendant to proceed with different retained counsel.").

212. Fla. Stat. AnN. § 27.711(12) (West Supp. 2003). Although Texas does not have a formal monitoring program, it appears to authorize preventive monitoring with respect to the timeliness of the postconviction petition. Tex. Code Crim. Proc. Ann. art. $11.071 \S \S 4(\mathrm{~d}), 4 \mathrm{~A}(\mathrm{a}), 4 \mathrm{~A}(\mathrm{~b})(3)$ (Vernon Supp. 2004-2005) (authorizing postconviction courts to appoint new counsel if original counsel fails to comply with filing deadline). According to the statute, the criminal appellate court may excuse the failure upon a 
further, requiring the monitoring entity to "monitor the performance of defense counsel to ensure that the client is receiving high quality legal representation" 213 - a standard that far exceeds Strickland's "reasonable professional assistance" standard. ${ }^{214}$

Use of a preventive standard to evaluate the conduct of counsel in ongoing proceedings is not unusual. Indeed, in the context of determining whether to remove counsel from an on-going criminal proceeding - a context, which, like monitoring, is intended to ensure effective performance ${ }^{215}$ - courts apply a preventive standard. For example, courts will grant requests for removal upon a showing of "good cause," 216 a term that has been interpreted to include not just actual ineffectiveness, such as a conflict of interest, ${ }^{217}$ but

showing of "cause as to why the application was untimely filed," $i d . \S \S 4 \mathrm{~A}(\mathrm{a}), 4 \mathrm{~A}(\mathrm{~b})$, a showing that would not appear to include a demonstration of how the failure actually prejudiced the capital inmate.

Unlike Florida (and possibly Texas), Ohio, which requires monitoring of capital trial and appellate counsel, has adopted a corrective standard. It permits a remedy only when the "attorney has ignored basic responsibilities of providing competent counsel, which results in prejudice to the defendant's case." ОноО Rev. Code Ann. Sup. CT. R. 20.V (West 2000) (emphasis added). The same appears to be true with Louisiana, which also requires monitoring of capital trial and appellate counsel. It specifies that "the attorney shall not be considered certified for purposes of appointment in capital cases" when "there is compelling evidence that an attorney has inexcusably ignored basic responsibilities of an effective lawyer, resulting in prejudice to an indigent client's case." La. Rev. Stat. Ann. Rule XXXI(West Supp. 2004) (emphasis added).

Interestingly, both the Ohio and Louisiana statutes use language similar to the 1989 version of the ABA Guidelines. See infra note 213 and accompanying text. In the 2003 version of the ABA Guidelines, the ABA consciously changed the monitoring standard from a corrective one to a preventive one. See infra note 213 and accompanying text. Perhaps the ABA's change will inspire Ohio and Louisiana to adopt a preventive monitoring standard as well.

213. 2003 ABA Guidelines, supra note 2, at Guideline 7.1, at 970. The ABA adopted this preventive standard in its 2003 version of the $A B A$ Guidelines because the prior version, published in 1989, contained an "insufficiently stringent" standard. Id. at Guideline 7.1, at 971 . The 1989 version, which required monitoring for "quality representation," 1989 ABA GuIDELINES, supra note 35, at Guideline 7.1, con tained a corrective standard as the main monitoring standard. Id. (providing that counsel should be removed from the roster of eligible attorneys when "there is compelling evidence that an attorney has inexcusably ignored basic responsibilities of an effective lawyer, resulting in prejudice to the client's case") (emphasis added). The prior version appeared to use a preventive standard in instances where counsel suffered "a mental or physical impairment," as it made no reference to a showing of actual prejudice. See id. ("Where the assigned lawyer is unable to provide affective [sic] representation due to a mental or physical impairment, the Court may be forced to intervene.").

214. Strickland v. Washington, 466 U.S. 668, 689 (1984). As explained below, this preventive standard exceeds the demands of the meaningfulness requirement.

215. See Wayne R. LaFave et al., Criminal Procedure § 11.6(a), at 597 (2d ed. 1999) (noting that "[t]he issue of client control" over attorney conduct arises not only through ineffectiveness challenges, but also through requests for new counsel, whether appointed or retained).

216. E.g., United States v. Lott, 310 F.3d 1231, 1249 (10th Cir. 2002).

217. See, e.g., id. at 1249 (holding that a conflict of interest constitutes good cause for removal); People v. Sawyer, 453 N.Y.S.2d 418, 422 (1982) (noting that "a genuine conflict of interest would entitle 
also a potential for ineffectiveness. Thus, courts allow removal and substitution of counsel if the "conflict between the defendant and his counsel was so great that it resulted in a total lack of communication preventing an adequate defense." 218 Similarly, courts may refuse requests for removal and substitution of counsel if the substitute counsel requested by the defendant might have a conflict of interest. ${ }^{219}$ And, with or without a request by the defendant, courts can remove counsel if counsel's personal circumstances make effective performance unlikely. ${ }^{220}$ Finally, even without a request for removal, courts have removed counsel when "counsel's performance ... could arguably give rise to future claims of ineffective assistance. ${ }^{221}$

a defendant to relief").

218. United States v. Allen, 789 F.2d 90, 92 (1 st Cir. 1986)(emphasis added); see also Lott, 310 F.3d at 1250 (noting that "[e]ven if a defendant's counsel is competent, a serious breakdown in communication can result in an inadequate defense"). Removal will not be permitted if "the defendant substantially and unjustifiably contributed to the breakdown in communication." E.g., Romero v. Furlong, 215 F.3d 1107, 1113 (10th Cir. 2000) (finding that removal was unwarranted when "defendant's difficulties [with counsel] were the product of his negative attitude toward the proceedings and not a justifiable reaction to some outside influence or event").

219. In Wheat v. United States, 486 U.S. 153, 162-63 (1988), the Court upheld the district court's refusal to grant a request for substitute counsel on the ground that the substitution might result in a conflict of interest. As the Court reasoned:

$[T]$ he district court must be allowed substantial latitude in refusing waivers of conflicts of interest not only in those rare cases where an actual conflict may be demonstrated before trial, but in the more common cases where a potential for conflict exists which may or may not burgeon into an actual conflict as the trial progresses.

Id. at 163 (emphasis added). The latitude is necessary because "a district court must pass on the issue [of conflict of interest] not with the wisdom of hindsight after the trial has taken place, but in the murkier pretrial context when relationships between parties are seen through a glass, darkly." Id. at 162.

220. See, e.g., Smith v. Superior Court, 440 P.2d 65, 72 (Cal. 1968) (noting that, in instances where "defendant's attorney exhibits objective evidence of physical incapacity to proceed with a meaningful defense of his client, such as illness, intoxication, or a nervous breakdown," the court "should inquire into the matter on its own motion, and if necessary relieve the affected counsel and order a substitution"); Sawyer, 438 N.E.2d at 1137 (noting that the "existence of a personal impediment which handicaps [counsel's] professional performance" would justify removal); Tennessee v. Huskey, 82 S.W.3d 297, 307 (Tenn. Crim. App. 2002) (noting that courts may involuntarily remove counsel if necessary because of "objective evidence of physical incapacity to proceed with a meaningful defense") (internal citation and quotation omitted).

Courts must carefully scrutinize the need for removal in instances where the defendant does not request it, as removal implicates the "defendant's right to counsel of his choice," as well as the independence of counsel. Id.; see also, e.g., People v. Lucev, 233 Cal. Rptr. 222, 225 (Cal. Ct. App. 1986) (noting that involuntary removal can interfere "with the individual's desire to defend himself in whatever manner he deems best"). Nevertheless, if after such scrutiny the court determines that removal is necessary, it may do so. Smith, 440 P.2d at 72-73; see also, e.g., Huskey, 82 S.W.3d at 306-07.

221. Burke v. Nevada, 887 P.2d 267, 268 (Nev. 1994) (removing counsel because of failure to "prosecute th[e] appeal beyond the filing of the docketing statement"); Cudzey v. Nevada, 747 P.2d 233, 235 (Nev. 1987) (removing counsel because of inadequate opening brief and failure to file reply brief); see 
While the monitoring standard must be designed to prevent error, the meaningfulness requirement does not demand that it be designed to prevent all error, or even as much error as possible, without regard to the burden imposed on the government. Instead, the meaningfulness requirement calls for a standard that accommodates both the defendant's interests in receiving competent assistance and the government's interests in maintaining sovereign authority over its criminal proceedings.

The ABA's preventive standard, which appears to require an in-depth review of counsel's performance, improperly shifts the balance of interests too much in the defendant's favor. ${ }^{222}$ Its standard authorizes the monitoring entity to look for, and correct, any conduct that could be characterized as anything other than "high quality legal representation," a term deliberately chosen for its rigor. ${ }^{223}$ While this standard would significantly increase the likelihood of competent performance, it does so at great expense to the government. Although the ABA forbids the monitoring entity from "micro-manag[ing] counsel's work," 224 compliance with the standard would appear to require something just short of micro-managing, for it is difficult to imagine how the monitoring entity would discover the lack of high quality representation without spending considerable time and resources studying the capital

also Lucev, 233 Cal. Rptr. at 225 (noting the rule that "counsel may also be relieved on a trial court's own motion, even over the objection of a defendant or his counsel, to eliminate potential conflicts, ensure adequate representation, or prevent impairment of court proceedings") (internal quotation and citation omitted) (emphasis added); Huskey, 82 S.W.3d at 307 (noting rule that courts may involuntarily remove counsel not only because of "actual conflict," but also because of "serious potential for conflict"). Involuntary removal is inappropriate if based only on "the judge's subjective opinion that the attorney is "incompetent," "as it unduly interferes with the "defendant's right to counsel of his choice [and] the independence of the bar." Smith, 440 P.2d at 72-73; see also People v. Johnson, 547 N.W.2d 65, 69 (Mich. Ct. App. 1996) (noting rule); Huskey, 82 S.W.3d at 307 (same).

222. While the meaningfulness requirement does not demand that states use the ABA standard, the states of course would be free to adopt it. Indeed, they should be encouraged to do so, as it is commendably rigorous and would go a long way toward ensuring competent performance. Given that some death penalty states provide post-performance reviews to ensure the delivery of effective assistance of capital postconviction counsel, see Andrew Hammel, Diabolical Federalism: A Functional Critique and Proposed Reconstruction of Death Penalty Federal Habeas, 39 AM. CRIM. L. Rev. 1, 59 (2002), which is something they are not required to do under the meaningfulness requirement, it is not unrealistic to think that some states might also adopt a monitoring standard that exceeds the demands of the meaningfulness requirement.

223. The ABA adopted the "high quality legal representation" standard because it believed the old standard was "insufficiently stringent." 2003 ABA Guidelines, supra note 2, at Guideline 7.1, at 971. The old standard required the monitoring entity to monitor for "quality representation" and to determine whether the attorney had "inexcusably ignored basic responsibilities of an effective lawyer, resulting in prejudice to the client's case." 1989 ABA Standards, supra note 35, at Guideline 7.1.

224. 2003 ABA Guidelines, supra note 2, at Guideline 7.1, at 973. 
inmate's case and evaluating the wisdom of counsel's decisions. Indeed, by the ABA's own account, the monitoring entity must "systematic[ally] review" 225 counsel's performance in search of "any substandard performance. ${ }^{, 226}$ Moreover, the ABA requires the monitoring entity to use its recommended performance standards during the monitoring process. ${ }^{227}$ These standards, which address the duties of postconviction counsel, are commendably thorough, and will be of immense help to anyone appointed to represent a capital inmate at any stage of the process. But, monitoring for full compliance with the standards, something that would appear necessary to guarantee "high quality legal representation," will take substantial effort. For example, the performance standards require counsel to "[e]stablish[] a relationship of trust with the client." ${ }^{\prime 28}$ How does the monitoring entity verify compliance without actually attending all meetings between counsel and the client? The performance standards also require postconviction counsel to "continue an aggressive investigation of all aspects of the case." 229 But, again, how can the monitoring entity ensure that such an aggressive investigation occurs without extensive familiarity with the substance of the case?

A properly balanced preventive standard is one that protects competent performance by requiring the monitoring entity to search for objectively identifiable signs of actual and potential incompetence. ${ }^{230}$ While the ABA's performance standards certainly are relevant under this standard, application of the standard would not require monitoring for full compliance with those performance standards. Thus, the monitoring entity need not scrutinize substantive decisions, look for possible claims, follow the substantive scope of the investigation, or assess the value of the evidence uncovered during the investigation. $^{231}$ Instead, the proposed monitoring standard charges the monitoring entity with searching for objectively identifiable signs that counsel is, or might be, performing incompetently, such as a failure to complete basic

225. Id. The ABA does not specify precisely what this term means, but it assuredly does extend beyond reacting to complaints filed by the defendant or others familiar with counsel's performance. See $i d$. ("[A]n effective attorney-monitoring program in death penalty matters should go considerably beyond" investigating and responding to complaints about counsel's performance.).

226. $I d$. at Guideline 7.1, at 974 .

227. Id. at Guideline 10.1, at 992.

228. Id. at Guideline 10.5 , at 1008 .

229. Id. at Guideline 10.15.1, at 1080 .

230. See Schwarzer, supra note 40, at 657-58 (recommending that the trial judge can look for objectively identifiable signs of actual or potential incompetence which Judge Sch warzer called "danger signal[s]" or "alerting circumstances"); see also Levine, supra note 40, at 1433 (noting that judges can search for "alerting circumstances" when monitoring trial counsel).

231. See supra notes $156,157,163,166$ and accompanying text. 
steps to investigate the case or failure to submit discovery requests. As explained in the following section, this standard focuses the monitoring entity's attention predominantly on counsel's basic efforts to prepare to file the postconviction petition. While this proposed standard will not prevent all instances of incompetence, it assuredly will increase the likelihood of competent assistance.

One might challenge the proposed monitoring standard on the ground that it provides greater protection for the effectiveness of postconviction counsel than for trial or appellate counsel, as the defendants who seek to challenge the performance of trial and appellate counsel must satisfy the Strickland standard. This argument is without merit, however, because duringperformance reviews, by their nature, are less advantageous than postperformance reviews. During-performance reviews are not conducted with the benefit of hindsight and, even with a preventive standard, do not guarantee competent performance. Post-performance reviews, on the other hand, are conducted with the benefit of hindsight, and, thus, serve as a forum in which to raise all errors. While it is true that Strickland allows a remedy only for those errors that undermine the reliability of the proceeding, duringperformance reviews do not guarantee even this level of relief. If (and, likely, when) monitoring fails to prevent an error-even one that impacts the reliability of the postconviction proceeding - there is no constitutionally required remedy. ${ }^{232}$ As this author has argued elsewhere, the government is not required to conduct post-performance reviews of capital postconviction counsel's performance, making during-performance reviews the end of the line for protecting the effectiveness of capital postconviction counsel. ${ }^{233}$

One might also argue that Strickland is the better standard for duringperformance reviews because it was designed to address the finality concerns associated with effectiveness challenges. ${ }^{234}$ But this argument fails because post-performance effectiveness challenges, which Strickland was designed to address, pose a greater risk to finality than during-performance challenges. If the defendant succeeds in demonstrating ineffective assistance of counsel in a post-performance review, she is entitled to a new proceeding with new counsel, a remedy that naturally undermines the government's finality

232. This assumes, of course, that the monitoring entity performed adequately. A remedy might indeed be constitutionally required if the monitoring entity completely fails to monitor, or monitors inadequately. But that is a question for another day. See supra notes 179, 195.

233. McConville, supra note 13, at 104-10.

234. See Strickland v. Washington, 466 U.S. 668, 691-94 (1984) (discussing finality concerns in connection with prejudice prong). 
interests. And the more lenient the standard for proving ineffectiveness, the greater the impact that post-performance reviews will have on the government's finality interests. Strickland recognized this point, and established a fairly strenuous effectiveness standard. ${ }^{235}$

During-performance reviews, on the other hand, pose no greater risk to finality than that which exists by virtue of the postconviction process itself. Postconviction review provides an opportunity for criminal defendants to continue challenging the constitutionality of their convictions and sentences. Monitoring does not increase this opportunity, but rather protects it by ensuring, to the extent possible, that counsel acts with a certain level of competence throughout the postconviction proceeding. If the capital defendant has a meritorious claim on postconviction review, she is entitled to relief. A more lenient monitoring standard does not increase the meritorious nature of the claim; it merely makes it more likely that the claim will be presented.

\section{Application of the Monitoring Standard}

As the discussion above reveals, the monitoring process is really one of detection, intervention, and prevention, with the monitoring entity searching for signs of possible problems with counsel's performance and then seeking to solve those problems before any lasting damage occurs. This section discusses the actual detection process, first explaining the basic signs that indicate counsel is, or might be, performing incompetently, and then explaining the process for gathering the information necessary to assess counsel's performance. ${ }^{236}$

\section{Searching for Basic Signs of Actual and Potential Incompetence}

The monitoring obligation extends not only to counsel's actual performance, but also to counsel's ability to perform competently. Thus, in addition to examining counsel's performance, the monitoring entity must look

235. See id. at 690 ("The availability of intrusive post-trial inquiry into attorney performance ... would encourage the proliferation of ineffectiveness challenges. Criminal trials resolved unfavorably to the defendant would increasingly come to be followed by a second trial.").

236. The questions of how to detect and remedy problems with counsel's performance are relevant when constructing any system of monitoring, whether at trial, on direct appeal, or on postconviction. See Klein, supra note 40, at 577-578 (discussing issues of detection and remedy in context of monitoring criminal trial counsel). 
for any circumstances suggesting that counsel is simply unable to perform competently. The primary example, of course, is the existence of a physical or mental impairment severe enough to impede competent representation, such as "illness, chemical dependency or some other [similar] handicap." 237 As the ABA explains, "[c]ircumstances can change [after counsel has been appointed], ${ }^{, 238}$ making monitoring for such problems quite important. ${ }^{239}$

In terms of actual performance, the best way to detect conduct that threatens the delivery of effective assistance is to monitor counsel's compliance with the basic duties required of all postconviction counsel, ${ }^{240}$ as failure to comply with these duties significantly increases the possibility that counsel will render constitutionally ineffective assistance. There are three such duties, all of which relate to the preparation for, ${ }^{241}$ and filing of, the postconviction petition: (1) the duty to conduct a thorough investigation of the entire case; (2) the duty to raise all potentially meritorious claims; and (3) the duty to file a timely petition. ${ }^{242}$ Each duty will be discussed in turn. ${ }^{243}$

237. 2003 ABA Guidelines, supra note 2, at Guideline 7.1, at 974. Indeed, the ABA has long advocated monitoring for the existence of physical and mental impairments that impede competent representation. See 1989 ABA Guidelines, supra note 35, at Guideline 7.1 (stating that if "the assigned lawyer is unable to provide affective [sic] representation due to a mental or physical impairment, the Court may be forced to intervene, on its own motion or at the request of the client (in propria persona or through the appointment authority"); 2003 ABA Guidelines, supra note 2, at Guideline 7.1, at 973-74 (noting that the monitoring entity "should intervene" if it determines that counsel is not "providing high quality legal representation ... because of a mental or physical impairment").

238. 2003 ABA Guidelines, supra note 2, at Guideline 7.1, at 974 n.127.

239. Precisely because physical or mental impairments can threaten the delivery of effective assistance, courts generally have no problem allowing withdrawal or removal of counsel if such circumstances exist. See, e.g., Cal. Rules of Court Policy Statement 2 (Deering 2004) (permitting withdrawal of counsel "when an appointed counsel becomes mentally or physically incapacitated"); Smith v. Superior Court, 440 P.2d 65, 72 (Cal. 1968) (noting that "[a]ll will agree that if the defendant's attorney exhibits objective evidence of physical incapacity to proceed with a meaningful defense of his client, such as illness, intoxication, or a nervous breakdown," courts "should inquire into the matter, . . and if necessary relieve the affected counsel and order a substitution"); Tennessee v. Huskey, 82 S.W.3d 297, 307 (Tenn. Crim. App. 2002) (same).

240. See 2003 ABA Guidelines, supra note 2, at Guideline 10.1, at 992 (requiring monitoring entity to use performance standards when monitoring counsel's performance).

241. In the context of trial counsel, commentators have recognized the utility of monitoring counsel's level of preparation as a way of detecting and preventing error. See Klein, supra note 40, at 583 (noting that the "focus [of monitoring] should be on whether the lawyer has devoted the time necessary to prepare and investigate the client's case properly"); Levine, supra note 40, at 1431 (noting that scholarly recommendations "now favor formal procedures which would reveal to the trial judge the extent to which defense counsel has undertaken preparatory steps such as discovery, investigation, and assessment of the admissibility of evidence"); Schwarzer, supra note 40, at 654 (recommending monitoring trial counsel's preparation because "[a]dequate preparation lies at the heart of a competent trial performance"); Tague, supra note 40, at 161-65 (discussing importance of monitoring trial counsel's preparation).

242. Compliance with these duties is essential to effective assistance, as demonstrated by the case 


\section{a. The Duty To Investigate}

Counsel has a duty to conduct a thorough investigation of the underlying crime, the defendant's background, and the prior proceedings in the defendant's case, ${ }^{244}$ all in an effort to uncover possible grounds for relief. ${ }^{245}$ Obviously, such investigations are critical to the ultimate success of the

of Max Alexander Soffar, a capital inmate in Texas who won habeas relief because of the diligent work of state and federal postconviction counsel. Soffar v. Dretke, 368 F.3d 441 (5th Cir. 2004). Soffar's trial counsel failed "to take the most elementary step of attempting to interview the single known eyewitness to the crime with which their client was charged," $i d$. at 473-74, even though counsel "must have been aware" that the witness's statements conflicted in many respects with the defendant's confession, and thus could have been used to undermine the reliability of the confession. $I d$. at 474. Trial counsel also neglected to obtain the opinion of a ballistics expert in the face of "readily apparent discrepancies between the ballistics evidence and the State's theory of the case." Id. at 476. State postconviction counsel discovered these errors and raised an ineffective assistance claim (as well other claims) in the state petition. Federal postconviction counsel followed suit, raising the claim in a timely federal petition. Although the state postconviction courts and the federal district court denied relief, the Fifth Circuit granted the habeas petition, finding trial counsel's conduct both unreasonable and prejudicial under Strickland. Accordingly, the court vacated both the conviction and the sentence. Id. at 473-78. Had Soffar's state and federal postconviction counsel failed in any of their duties (investigation, raising claims, and filing timely petitions), Soffar would not have obtained relief.

243. Counsel also has a duty to perform competently at any evidentiary hearing ordered by the state or federal postconviction court. Such hearings generally are necessary when there is a factual dispute relating to a claim in the petition. See LARRY W. YackLe, Postconviction Remedies $§ 124$, at 481-82 (1981) (“[A] hearing [on federal habeas] is not required unless historical, primary facts are in dispute."). Of course, such a hearing will not be ordered unless counsel first conducts the necessary investigation and discovers the relevant facts and potential claims. Accordingly, this section addresses how to monitor for compliance with the three basic duties relating to preparation for, and filing of, the postconviction petition.

244. E.g., 2003 ABA Guidelines, supra note 2, at Guideline 10.7, at 1015 (including duty to investigate as part of professional performance standard); Texas Defender Service, supra note 5, at 12 (discussing duty to investigate). At least two states - California and Texas-impose a statutory obligation on capital postconviction counsel to conduct an investigation for possible claims. See Cal. Rules of Court Policy Statement 3 (Deering 2004) ("Habeas corpus counsel in a [sic] capital cases shall have a duty to investigate factual and legal grounds for the filing of a petition for a writ of habeas corpus."); TEX. Code Crim. Proc. AnN. art. 11.071 § 3(a) (Vernon Supp. 2004-2005) (“On appointment, counsel shall investigate expeditiously ... the factual and legal grounds for the filing of an application for a writ of habeas corpus.").

245. While California imposes a duty to investigate for possible claims, it does not authorize a scorched earth investigation designed to uncover all potential claims:

The duty to investigate does not impose on counsel an obligation to conduct, nor does it authorize the expenditure of public funds for, an unfocused investigation having as its object uncovering all possible factual bases for a collateral attack on the judgment. Instead, counsel has a duty to investigate potential habeas corpus claims only if counsel has become aware of information that might reasonably lead to actual facts supporting a potentially meritorious claim.

Cal. Rules of Court Policy Statement 3 (Deering 2004). 
postconviction petition. ${ }^{246}$ They also are laborious. As the Texas Defender Service described the job of state postconviction counsel:

To present any arguably meritorious claim, the state habeas counsel must perform a thorough investigation of the case, starting with the written record of the trial, but exploring far beyond it. The lawyer must contact and interview all important witnesses, scrutinize the files of all previous defense attorneys, look for issues inadequately investigated or presented and examine the state's case file for evidence that may have been withheld from the defense or for indications that state witnesses may have given false or misleading testimony. The lawyer must investigate and gather all available mitigating information about the defendant's background, including any history of mental health problems, brain damage, genetic disorders or physical or sexual abuse. The state habeas lawyer must uncover any new evidence of violations of the defendant's rights, information demonstrating that the conviction or sentence was tainted by error of constitutional magnitude, but was not preserved for the jury. ${ }^{247}$

While these same obligations apply to federal postconviction counsel, ${ }^{248}$ they are critically important at the state habeas stage because, as a general matter, claims must be raised properly in state court in order to be considered on the merits in federal court. ${ }^{249}$

The monitoring entity cannot ensure a quality investigation in each case without essentially looking over counsel's shoulder during the entire investigation, and, as discussed above, the meaningfulness requirement does not go this far. The monitoring entity can, however, fairly easily determine whether counsel has failed to conduct any investigation whatsoever. It can also look for objectively identifiable outward signs that counsel is (or is not) conducting an adequate investigation. ${ }^{250}$ The main way to do this is to

246. See Texas Defender Service, supra note 5, at $\mathrm{x}$ (noting that investigation assists counsel in raising meritorious claims). It is especially important for state postconviction counsel to conduct an adequate investigation, for, under the new habeas rules established by the AEDPA, federal habeas courts may not, except in narrow circumstances, order an evidentiary hearing on a claim if the capital inmate "has failed to develop the factual basis of [the] claim in State court." 28 U.S.C. § 2254(e) (2000); see also Texas Defender Service, supra note 5, at 14 ("If counsel does not request discovery in state habeas, it is not available in later federal habeas proceedings.”) (citing 28 U.S.C. § $2254(\mathrm{e})$ ).

247. Texas Defender Service, supra note 5, at 12; see also Mello, supra note 14, at 544-46 (describing the duties of capital postconviction counsel). For an article discussing the ethical obligations of trial counsel in postconviction proceedings, see David M. Siegel, My Reputation or Your Liberty (or Your Life): The Ethical Obligations of Criminal Defense Counsel in Post Conviction Proceedings, $23 \mathrm{~J}$. LEgAL Prof. 85 (1998-1999).

248. See 2003 ABA Guidelines, supra note 2, at Guideline 10.15.1, at 1085 (discussing the duties of both state and federal postconviction counsel); McConville, supra note 13, at 91-94 (same).

249. See supra note 18 and accompanying text; see also Texas Defender Service, supra note 5 , at 12 (noting that state postconviction counsel must thoroughly investigate the case, because "only claims that have been litigated before state courts are reviewable in federal court").

250. Monitoring for inadequate investigations likely will bear fruit, at least in Texas. In its recent 
determine whether counsel has taken the basic steps necessary to investigate the case. ${ }^{251}$ The performance standards contained in the ABA Guidelines can help in this endeavor ${ }^{252}$ because they outline not only the basic areas of investigation, but also contain a useful list of objectively identifiable steps in an adequate investigation. ${ }^{253}$ For example, counsel should interview relevant parties (for example, the client ${ }^{254}$ and possible witnesses), ${ }^{255}$ obtain any evidence and expert reports in the government's possession, ${ }^{256}$ and visit the crime scene. ${ }^{257}$ She should also acquire information regarding the defendant's

study of the performance of counsel in Texas state postconviction cases, the Texas Defender Service found that "death row inmates ... face a one-in-three chance of being executed without having the case properly investigated and with out having any claims of innocence or unfairness presented or heard." Texas Defender Service, supra note 5, at 2. And, it is not as if meritorious claims are non-existent or undiscoverable, for "new lawyers appointed by federal courts after the filing of the state habeas petition [often] discover new evidence of serious and substantial mistakes in the original trial." Id. at 22.

251. In the trial context, Judge Schwarzer recommends that trial judges look for "danger signal[s]" suggesting that counsel has not performed basic investigative duties. Schwarzer, supra note 40 , at 657 ; id. at 654-58 (discussing the basic steps for an investigation).

252. Commentators have recognized the utility of using performance standards published by the ABA when monitoring the performance of trial counsel. Klein, supra note 40, at 582 (noting that a monitoring "worksheet could be based on the ABA's Standards for the Administration of Criminal Justice, Chapter Four: The Defense Function"); Schwarzer, supra note 40, at $654 \&$ nn.94-98 (recommending the use of ABA's Standards Relating to the Administration of Criminal Justice, The Defense Function $\S \S 3.2(\mathrm{a})$, 3.5(a), 3.6(a), 4.1, 5.1 (1974)); Tague, supra note 40, at $164 \mathrm{n} .285$ (recommending a monitoring "checklist [that] would follow the ABA guidelines").

253. See 2003 ABA Guidelines, supra note 2, at Guideline 10.7, at 1015-27. Two recent Supreme Court decisions involving ineffective assistance of counsel in death penalty cases support the use of ABA performance standards to measure the quality of counsel's performance. In Wiggins v. Smith, 539 U.S. 510 (2003), for example, the Supreme Court used the 1989 version of the ABA GuIDELINES as evidence that capital trial counsel performed ineffectively by limiting their investigation for mitigating evidence. $I d$. at 524 (citing 1989 ABA Guidelines, supra note 35, at Guideline 11.4.1(C)). And, in Williams v. Taylor, 529 U.S. 362 (2000), the Supreme Court used the ABA's StandARds for Criminal Justice as evidence that capital trial counsel performed ineffectively by failing to discover and present a "voluminous amount of" available mitigating evidence. $I d$. at 396 (citing 1 ABA, ST ANDARDSFOR CRIMINAL JUSTICE 4-4.1, cmt. at 4-55 (2d ed. 1980)). For a brief discussion of these cases, see infra note 270.

254. See 2003 ABA Guidelines, supra note 2, at Guideline 10.5, at 1005 (requiring counsel to keep client apprised of "the progress of and prospects for the factual investigation, [as well as] what assistance the client might provide with it").

255. These include:

(1) eyewitnesses or other witnesses having purported knowledge of events surrounding the alleged offense itself; (2) potential alibi witnesses; (3) witnesses familiar with aspects of the client's life history that might affect the likelihood that the client committed the charged offense(s), and the degree of culpability for the offense[; . . . [and] (4) members of the victim's family. Id. at Guideline 10.7, at 1019-20.

256. Id. at Guideline 10.7, at 1020 ("Counsel should make a prompt request to the relevant government agencies for any physical evidence or expert reports relevant to the offense or sentencing, as well as underlying materials.").

257. Id. at Guideline 10.7, at 1020. 
"personal and family history," 258 which is necessary to build a case in mitigation. ${ }^{259}$ And she should interview defendant's former counsel and review their files. ${ }^{260}$ These steps are not exhaustive, but are mentioned only to demonstrate how the monitoring entity can check the progress of an investigation - and detect an inadequate investigation - without delving into the substance of counsel's investigation or monitoring for full compliance with the ABA's detailed performance standards. ${ }^{261}$ All the monitoring entity need do is inquire whether counsel has taken the above steps. A negative answer would suggest possible incompetence, and would be enough to justify intervention by the monitoring entity. ${ }^{262}$

The monitoring entity can also assess the adequacy of an investigation by inquiring whether counsel has investigated for evidence of common and frequently successful claims, such as ineffective assistance of trial and appellate counsel. ${ }^{263}$ Failure to investigate such claims, given their chances of success, usually signals an inadequate investigation. Moreover, monitoring for these claims at least points counsel in the direction of a potentially

258. Id. at Guideline 10.7, at 1022 .

259. See id. at Guideline 10.7, at 1021-26 (describing investigation for propriety of penalty).

260. Id. at Guideline 10.7, at 1015.

261. Cf. Klein, supra note 40, at 581 ("Unlike some other aspects of client representation, the degree of pretrial preparation can be objectively assessed and evaluated.").

262. See Schwarzer, supra note 40, at 654-56 (discussing the need, in a trial context, to engage in further inquiry if a trial judge detects deficient preparation); see also infra notes 341-47 and accompanying text. Monitoring for compliance with the basic steps in the investigation process might not prevent all errors in all cases, but it should prevent what happened to Bryan Eric Wolfe, a capital inmate in the State of Texas. As described by Judge Baird:

The... application appears to allege ineffective assistance of trial counsel, but also includes a wish list of discovery, research, and hearings necessary to represent applicant. No cases are cited. No analysis of the law is presented. Indeed, even the State recognizes this 'application' appears to be a motion for discovery.

Ex Parte Wolfe, 977 S.W.2d 603, 603 (Tex. Crim. App. 1998) (Baird, J., dissenting) (emphasis added); see also Texas Defender Service, supra note 5, at $11 \&$ n.44 (citing Wolfe's petition as one in which "serious deficiencies" existed). Despite these problems with the petition, the state court denied Wolfe's petition, over Judge Baird's dissent. Wolfe, 977 S.W.2d at 603.

263. See Dwight Aarons, Getting Out of This Mess: Steps Toward Addressing and Avoiding Inordinate Delay in Capital Cases, 89 J. CRIM. L. \& CRIMINology 1, 72 (1998) (stating that ineffective assistance claims represent the most common claim at the postconviction stage) (internal citation omitted); Donald F. Roeschke, Strategies for Enforcing the Right to Effective Representation, 46 AM. JuR. TRIALS 571,582 (1993) ("Ineffective representation claims are one of the most frequently raised issues in postconviction proceedings in both the state and federal courts."); Liebman et al., supra note 1, at ii, App. C-4 (noting that ineffective assistance of counsel was a common basis for relief in state postconviction cases reviewed in study). 
lucrative line of investigation, hopefully preventing counsel from completely missing a meritorious claim. ${ }^{264}$

Such monitoring might well have helped Walter Hill, a capital inmate in Alabama whose first state postconviction counsel failed to detect and raise trial counsel's failure, among other things, to investigate and present mitigating evidence at his sentencing hearing. ${ }^{265}$ Had counsel performed an adequate investigation, he very likely would have discovered the ineffectiveness claim - it was, after all, discovered and raised in Hill's second state postconviction petition. ${ }^{266}$ Unfortunately, by the time Hill filed the second petition, it was too late; the state court dismissed the claim as procedurally defaulted. ${ }^{267}$ This, in turn, caused the federal courts to reject the claim on procedural grounds as well. ${ }^{268}$ Tragically, the ineffectiveness claim might well have been successful had it been properly raised during state postconviction review. At sentencing, the trial judge found "no mitigating circumstances," 269 so the existence of some mitigating evidence - that is, the evidence trial counsel should have discovered and presented - might have changed the outcome of the sentencing proceeding. ${ }^{270}$ And, under Strickland, a "reasonable probability"271 that counsel's deficient performance affected the

264. For a thorough discussion of how postconviction counsel ought to investigate and raise claims of ineffective assistance of trial and appellate counsel, see Roeschke, supra note 263, §§ 9-27.

265. Hill v. Jones, 81 F.3d 1015, 1021-22 \& n.5 (5th Cir. 1996).

266. Id. at 1022 .

267. Id. at 1019 .

268. Id. at 1026 .

269. Id. at 1018-19.

270. Had the ineffectiveness claim been raised today, it would have had a strong chance of success, given the Supreme Court's recent decisions in Williams v. Taylor, 529 U.S. 362 (2000), and Wiggins v. Smith, 539 U.S. 510 (2003). As the Ninth Circuit observed, both cases "stand for the proposition that counsel's failure to investigate and present mitigating evidence presents serious constitutional concerns." Stankewitz v. Woodford, 365 F.3d 706, 716 (9th Cir. 2004). In both Wiggins and Williams, the Court ruled that counsel had performed ineffectively in failing to adequately investigate for mitigating evidence. Wiggins, 539 U.S. at 524-25 (holding that trial counsel's decision to limit mitigation investigation when investigation extended to only a "narrow set of sources" and when investigation produced "evidence [that] would lead a reasonable attorney to investigate further was constitutionally ineffective"); Williams, 529 U.S. at 396 (holding that trial counsel's failure to investigate and present a "voluminous amount of [mitigating] evidence was constitutionally ineffective"). Equally significant, both decisions emphasized the importance of a thorough mitigation investigation. Wiggins, 539 U.S. at 524 (describing as a "well-defined norm[]" the ABA's requirement that the "investigations into mitigating evidence "should comprise efforts to discover all reasonably available mitigating evidence'") (quoting 1989 ABA GUIDELINES, supra note 35, at Guideline 11.41(C)) (emphasis in Wiggins); Williams, 529 U.S. at 396 (concluding that "trial counsel did not fulfill their obligation to conduct a thorough investigation of the defendant's background") (citing 1 ABA Standards For Criminal Justice, supra note 253, at 4-4.1, cmt. at 4-55 (2d ed. 1980)).

271. Strickland v. Washington, 466 U.S. 663, 694 (1984). 
outcome of the proceeding is sufficient to warrant a finding of constitutional ineffectiveness. Of course, we will never know whether trial counsel performed ineffectively. Walter Hill was executed by the State of Alabama on May 2, 1997, ${ }^{272}$ without ever having this claim addressed on the merits.

The monitoring entity can also evaluate the adequacy of an investigation by examining the number of hours postconviction counsel has logged working on the case. ${ }^{273}$ Representing a capital postconviction inmate is a timeintensive job, to say the least. As one death penalty lawyer observed: “To do ... a habeas case in the death penalty area and to do it right is a commitment of a thousand hours, perhaps more than a thousand hours. That's a lot of commitment. That's six month's of a lawyer's time." ${ }^{274}$ Naturally, the fewer the hours, the greater the chance that counsel has not performed her required duties, including the duty to investigate the case. ${ }^{275}$

Take, for example, the case of Johnny Joe Martinez, which was discussed at length by the Texas Defender Service in its recent study of the performance of state postconviction counsel in Texas. ${ }^{276}$ Martinez's state postconviction lawyer spent "less than 50 hours on the case," hardly a sufficient amount of time to conduct an investigation, let alone perform all of his other

272. Death Penalty Information Center, Executions in the U.S. in 1997, at http://www.death penaltyinfo.org/article.php?scid $=8 \& d i d=473$ (last visited Nov. 29,2004 ). Walter Hill is just one example of a capital inmate whose postconviction counsel defaulted a potentially meritorious ineffectiveness claim on postconviction review. There are others, including Tony Albert Mackall and Johnny Joe Martinez. See Martinez v. Johnson, 255 F.3d 229, 23 8-41 (5th Cir. 2001); Mackall v. Angelone, 131 F.3d 442, 446 (4th Cir. 1997). The State of Virginia executed Mackall on February 10, 1998, and the State of Texas executed Martinez on May 22, 2002. Death Penalty Information Center, Executions in the U.S. in 1998, at http://www.deathpenaltyinfo.org/article.php?scid=8\&did=474 (last visited Nov. 29, 2004); Texas Defender Service, supra note 5, at 34 .

273. See Texas Defender Service, supra note 5, at 31 (citing the number of hours worked as evidence of incompetence).

274. Sean Groom, Death Penalty Lawyers, WASH. Law. 20, 23 (Aug. 2002), at http://www.dcbar. org/for_lawyers/washington_lawyer/august_2002/penalty.cfm (last visited Nov.29, 2004) (quoting Douglas G. Robinson); see also Bright, Elected Judges, supra note 171, at 1824 (discussing the number of hours required to litigate postconviction petitions). One thousand hours might be a conservative number. In its 2003 ABA Guidelines, the ABA cited a survey of capital postconviction cases in Florida indicating that “"over 3,300 lawyer hours are required to take a post-conviction death penalty case from the denial of certiorari by the United States Supreme Court following direct appeal to the denial of certiorari [from state post-conviction proceedings.]"' 2003 ABA Guidelines, supra note 2, at Guideline 6.1, at 969 (quoting THE Spangenberg Group, Amended Time \& Expense Analysis of Post-Conviction Capital Cases in FLORIDA 16 (1998)).

275. Cf. Groom, supra note 274, at 23 (reporting instance where capital trial counsel "asked the judge for an extra 45 minutes at lunch to prepare for the sentencing phase of the trial because he hadn't yet done any preparation for it").

276. Texas Defender Service, supra note 5, at 30-34. 
responsibilities. ${ }^{277}$ Not surprisingly, he did not discover that trial counsel failed to "develop substantial and easily accessible" evidence to mitigate Martinez's crime. ${ }^{278}$ As a result, postconviction counsel failed to raise an ineffectiveness challenge in the state postconviction petition. ${ }^{279}$ The ineffectiveness claim was finally discovered during federal habeas review, when newly appointed counsel conducted an investigation that revealed Martinez's "extremely traumatic childhood." ${ }^{280}$ Specifically:

His mother drank heavily, was a victim of physical abuse, and sold heroin. Martinez was a witness to this physical abuse and drug dealing. Martinez had been sexually abused by a neighbor who repeatedly sodomized him and paid him not to disclose the abuse. At age 14 , because of the disturbing situation at home, Martinez was living under bridges or with friends and relatives when possible. ${ }^{281}$

Despite the disturbing nature of this evidence, and its potential weight in mitigation, Martinez's ineffectiveness claim had virtually no chance of success on federal habeas, as state postconviction counsel's failure to raise it in state court made "failure in federal court ... a foregone conclusion." 282 The State of Texas executed Martinez on May 22, 2002. ${ }^{283}$

In addition to the number of hours the attorney has worked on the case, the existence (or non-existence) of discovery requests submitted by the attorney can provide an indication of whether she is conducting an adequate investigation. ${ }^{284}$ Such requests are important, as they assist counsel in obtaining "information that may prove helpful in presenting appropriate habeas corpus claims."285 Thus, failure to make such requests should signal

277. Id. at 31. The Texas Defender Service cited this fact as one example of why Martinez's lawyer was incompetent. Id.

278. Id. at 33 (citing Martinez, 255 F.3d at 238 n.8).

279. Martinez, 255 F.3d at 239; Texas Defender Service, supra note 5, at 33.

280. Texas Defender Service, supra note 5, at 33.

281. Id. at 33 .

282. Id. The Fifth Circuit denied relief on Martinez's ineffectiveness claim, ruling that it had been procedurally defaulted in state court. Martinez, 255 F.3d at 241.

283. Texas Defender Service, supra note 5, at 34.

284. The Texas Defender Service made the connection between discovery requests and the quality of the investigation in its recent study of the performance of state postconviction counsel in Texas:

Despite the statutory and ethical requirements of an expeditious investigation, in only 30 cases $(12 \%)$ that we reviewed did the appointed counsel file a motion for discovery, the process by which attorneys can invoke the power of the court to compel others to turn over requested information that may prove helpful in presenting appropriate habeas corpus claims. Id. at 13-14.

285. $I d$. 
to the monitoring entity that counsel is, or might be, conducting an inadequate investigation.

Finally, the monitoring entity can also assess the adequacy of the investigation by examining the length and content of the petition itself. Indeed, the Texas Defender Service used both factors in its recent study. ${ }^{286}$ A short petition suggests counsel has done little work, for as the Texas Defender Service explains:

Habeas applications filed by experienced and adequately funded counsel who conducted a comprehensive investigation generally run into the hundreds of pages. The need to address the factual issues in each case and the highly technical law applicable to habeas litigation dictates that they be lengthy. ${ }^{287}$

Naturally, a two-page, ${ }^{288}$ five-page, ${ }^{289}$ or even fifteen page ${ }^{290}$ petition falls far short of this ideal. ${ }^{291}$ And, in terms of content, a petition containing only claims that are inappropriate on habeas, ${ }^{292}$ or claims that are unsupported by evidence ${ }^{293}$ would surely suggest an inadequate investigation. ${ }^{294}$ As the Texas

286. Id. at 14-17. See also Bright, Elected Judges, supra note 171, at 1821-22 (using the existence of "patently inadequate pleadings" to demonstrate attorney incompetence).

287. Texas Defender Service, supra note 5, at 13.

288. Counsel for Carlos Granados filed a two-page petition. Id. at 14.

289. Counsel for Johnny Joe Martinez filed a five-page petition. Id. at 31 . This should not be surprising, given that he worked fewer than 50 hours on Martinez's case. Id.

290. Fifteen percent of the petitions reviewed in the Texas study "were 15 pages or less." Id. at 14. Nine percent of the petitions "were 10 pages or less," and, as the Texas Defender Service noted, this is "quite a feat, because the procedural requirements for habeas petitions usually consume five pages alone." Id.

291. As the Texas Defender Servicenotes, a long petition does not guarantee quality, for even "longer petitions [may] contain[] the wrong type of claims for state habeas, [and] be just as worthless." Id. at 14.

292. In Texas, for example, claims based on the record are appropriate only on direct review. E.g., $i d$. at 12 . Thus, their presence in a state habeas petition suggests no independent investigation for evidence of error outside the record. Id. at 13-15. While each state has its own particular set of rules regarding which claims are cognizable on postconviction review, as a general matter, the postconviction process is reserved for claims that could not have been raised on appeal. See YACKLE, supra note 243, §5, at 17; id. $\S 10$, at 43 . Thus, inappropriate claims would be those, as in Texas, reserved for direct appeal.

293. In Texas, for example, postconviction claims must be "based on facts and evidence found outside of the trial record." Texas Defender Service, supra note 5, at 12. Thus, a petition without "extrarecord materials" suggests counsel did not perform an adequate investigation. Id. at 15 . In its study, the Texas Defender service found that "in 97 cases (39\%), no extra-record materials reflecting [an] investigation were filed with the trial court." Id.; see also id. at 16-17 (discussing cases where postconviction counsel failed to support cognizable claims with material outside the record).

294. Sixty-seven percent of the petitions reviewed by the Texas Defender Service in its study contained either "claims based solely on the trial record" or claims with "no extra-record materials reflecting [an] investigation." Id. at 15. The Texas Defender Service used these facts to conclude that counsel in those cases had rendered incompetent assistance. Id. at 15-16. 
Defender Service observed, "[1]ike an automobile without an engine, [such petitions] will go nowhere." 295 For similar reasons, the monitoring entity should be on the lookout for petitions containing no claims, ${ }^{296}$ as well as petitions so lacking in substance as to be patently deficient. ${ }^{297}$

\section{b. The Duty To Raise All Nonfrivolous Claims}

While it might be considered the "hallmark of effective appellate advocacy" to discard weaker claims and focus only on stronger claims, ${ }^{298}$ such is not the case in capital litigation, ${ }^{299}$ especially capital postconviction litigation. The gravity of the death penalty, as well as the fact that claims not properly raised in state and federal postconviction petitions will be procedurally defaulted, ${ }^{300}$ demand that capital postconviction counsel raise all nonfrivolous claims. ${ }^{301}$ One need only look to the cases of Walter Hill and

\section{Id. at 15.}

296. The Texas Defender Service discovered such a petition in the case of Joe Garza, "whose appointed lawyer, instead of filing a petition, filed an Anders brief." Id. at 20. In that document, styled "“Counsel's Professional Evaluation," Garza's attorney stated his "“professional opinion"” that Garza's claims were “"frivolous and without merit." Id. at 21 n.107 (quoting Counsel's Professional Evaluation, Ex parte Garza, Writ. No. 73,850 (filed Mar. 2002)). Garza's attorney was removed and replaced with new counsel. Texas Defender Service, supra note 5, at 21.

297. Bryan Eric Wolfe's state postconviction counsel filed such a petition. See Texas Defender Service, supra note 5, at $11 \mathrm{n} .44$ (citing Wolfe's petition as one containing "serious deficiencies"). As described by Judge Baird, who dissented from the denial of the petition:

The ... application appears to allege ineffective assistance of trial counsel, but also includes a wish list of discovery, research, and hearings necessary to represent applicant. No cases are cited. No analysis of the law is presented. Indeed, even the State recognizes this 'application' appears to be a motion for discovery.

Ex parte Wolfe, 977 S.W.2d 603, 603 (Tex. Crim. App. 1998) (Baird, J., dissenting) (emphasis added). Monitoring for an adequate investigation should significantly reduce the likelihood that counsel will file such a petition.

298. Smith v. Murray, 477 U.S. 527, 536 (1986); see also Jones v. Barnes, 463 U.S. 745, 751-52 (noting that "[e]xperienced advocates since time beyond memory have emphasized the importance of winnowing out weaker arguments on appeal and focusing on one central issue if possible, or at most on a few key issues").

299. Geimer, supra note 201, at $100 \mathrm{n} .44$ (asserting that "the worst advice any attorney could be given in death penalty litigation" would be to "winnow[] ... weaker claims and focus[] on those more likely to prevail") (discussing Smith v. Murray, 477 U.S. 527 (1986)).

300. See supra notes 17-19 and accompanying text. See also 2003 ABA Guidelines, supra note 2, at Guideline 10.15.1, at 1086 ("Counsel should assume that any meritorious issue not contained in the initial application will be waived or procedurally defaulted in subsequent litigation, or barred by strict rules governing subsequent applications.").

301. 2003 ABA Guidelines, supra note 2, at Guideline 10.15.1, at 1086 ("As with every other stage of capital proceedings, collateral counsel has a duty ... to raise and preserve all arguably meritorious issues[, which] include not only challenges to the conviction and sentence, but also issues which may arise 
Johnny Joe Martinez, both of whom were represented by counsel who failed to uncover and raise claims of ineffective assistance, for evidence of what can happen when counsel fails to do so. ${ }^{302}$

Naturally, the monitoring entity cannot monitor for full compliance with the duty to raise all claims without knowing the identity of those claims. To acquire that knowledge, the monitoring entity essentially would have to conduct its own investigation of the case - a task not demanded by the meaningfulness requirement. But, this does not mean the monitoring entity cannot conduct some sort of check on counsel's compliance with this duty. For example, the monitoring entity can ask counsel to identify all claims raised in earlier (or separate) proceedings that must be preserved during the postconviction process. For state postconviction counsel, this would mean identifying claims raised on direct appeal that can again (and therefore must) be raised on postconviction review. ${ }^{303}$ For federal postconviction counsel, this would mean identifying claims raised at the state postconviction stage, which of course must be raised in the first federal habeas petition in order to be considered on the merits. ${ }^{304}$ Such an inquiry not only serves to remind counsel

subsequently."); Texas Defender Service, supra note 5, at 13 ("Given the current restrictions on bringing post-conviction claims, ... every possible legal argument [must be] made in the state habeas proceeding."); $i d$. at 64 (counsel must "investigate and file any claim that exists and is based upon facts outside the record"). When introducing the Texas Habeas Corpus Reform Act of 1995, Texas State Representative Pete Gallego emphasized the importance of raising all claims in the state habeas petition:

And we tell individuals that everything you can possibly raise the first time, we expect you to raise it initially, one bite of the apple, one shot .... What we're attempting to do here is to say "raise everything at one time." You get one bite of the apple. If you have to stick the kitchen sink in there, put it all in there, and we will go through those claims one at a time and make a decision. Ex parte Kerr, 64 S.W.3d 414, 418 (Tex. Crim. App. 2002) (quoting the statement of Texas state rep. Pete Gallego).

302. See supra notes $265-72,276-85$ and accompanying text.

303. Federal habeas petitioners must exhaust all possible state remedies before obtaining review of their claims on the merits in federal court. See, e.g., Coleman v. Thompson, 501 U.S. 722, 729-32 (1991) (explaining exhaustion and procedural default rules). Thus, if a claim can be raised during state postconviction proceedings, it must be raised in those proceedings in order to preserve the opportunity for federal review. As explained by Professors Hertz and Liebman:

Even if it is likely that the state postconviction courts will deny relief on a claim because the prisoner . . . raise $[\mathrm{d}]$ it at some earlier stage in the case ... federal preclusion doctrines require the prisoner to give serious consideration to raising the claim in order ... to avoid procedural default problems later on.

HERTZ \& LieBMAN, supra note $19, \S 6.2$, at 288. For state postconviction counsel, the number of claims that were raised in earlier proceedings and that must be raised again on postconviction review likely will be fairly small, because in general the postconviction process is reserved for claims that could not have been raised in an earlier appeal. See YACKLE, supra note 243 , § 5, at 17; id. § 10, at 43.

304. See 28 U.S.C. $\$ 2244$ (b)(2) (2000) (prohibiting, with narrow exceptions, "second or successive" petitions). Because the state postconviction process generally is limited to raising claims that could not be 
of the claims she must raise in the petition, but it also provides the monitoring entity with a list of claims to look for in the petition once it is filed.

Monitoring admittedly is more difficult with respect to new claims - that is, the claims that postconviction counsel is supposed to find during her thorough investigation of the case. ${ }^{305}$ Because the monitoring entity need not look over counsel's shoulder during the investigation process, it will not know the identity of all such claims and, therefore, cannot check to ensure they are raised in the petition. Perhaps the best thing the monitoring entity can do to prevent counsel from defaulting on new claims, aside from asking counsel to periodically produce a list of claims she intends to raise in the petition, is to monitor the adequacy of the investigation along the lines suggested above. For the more thorough the investigation, the more likely counsel will discover - and raise - new claims for relief.

\section{c. The Duty To File a Timely Postconviction Petition}

It goes without saying that counsel has a duty to file a timely postconviction petition, as failure to do so generally results in the dismissal of the petition. ${ }^{306}$ The best way to prevent noncompliance with this duty is to remind counsel of the deadline and to periodically check counsel's progress on the petition. Detecting actual noncompliance with the timely filing requirement - a clear sign of incompetence - is equally straightforward; the

raised in earlier appeals, see sources cited supra note 292, and because all federal claims raised in state court must be preserved on federal review, the duty to raise and preserve all claims that were raised in earlier proceedings likely falls more heavily on federal postconviction counsel.

305. Because, as a general matter, claims must be raised properly in state court in order to be considered on the merits in federal court, see sources cited supra note 17, the job of finding these claims largely falls on the shoulders of state postconviction counsel. McConville, supra note 13, at 92-93; see also Texas Defender Service, supra note 5, at 13 ("Given the current restrictions on bringing post-conviction claims, every possible shred of evidence must be compiled and every possible legal argument made in the state habeas proceeding; otherwise the claims may as well not exist."). Nevertheless, federal postconviction counsel must also conduct a thorough investigation, because the federal habeas court can excuse failure to raise the claims in state court if the petitioner "demonstrate[s] cause for the default and actual prejudice as a result of the alleged violation of federal law, or demonstrate[s] that failure to consider the claims will result in a fundamental miscarriage of justice." Coleman v. Thompson, 501 U.S. 722, 750 (1991).

306. E.g., 2003 ABA Guidelines, supra note 2, at 1087 ("As with every other stage of capital proceedings, collateral counsel has a duty ... to raise and preserve all arguably meritorious issues.") (emphasis added). Untimely filings unfortunately occur even in the death context. See Ex parte Smith, 977 S.W.2d 610, 612-15 (Tex. Crim. App. 1998); Texas Defender Service, supra note 5, at 18 n.86 (citing Writ in Ex parte Medina); Texas Defender Service, supra note 5, at $16 \mathrm{n} .69$ (citing Writ in Ex parte Colella). See also Bright, Elected Judges, supra note 171, at 1822-24 (discussing problem with untimely petitions). 
monitoring entity need only check with the postconviction court to determine whether the petition has indeed been filed by the established deadline.

As the discussion above demonstrates, while the monitoring entity cannot detect all problems with counsel's performance, by looking for objectively identifiable signs of actual or potential incompetence, the monitoring entity should be able to detect a fairly wide range of problems. Although imperfect from the capital inmate's standpoint, such monitoring will at least improve the level of competence, and therefore, the likelihood of effective assistance. And this, after all, is the goal of the monitoring requirement. ${ }^{307}$

\section{Gathering the Relevant Information}

Knowing the information that is relevant to assessing the performance of postconviction counsel is only one step in the monitoring process. The monitoring entity must also have in place a system for gathering that information. Without question, some information regarding counsel's performance will come to the monitoring entity unsolicited-from the defendant, the defendant's family, judges in front of whom counsel has appeared, or any other person with knowledge of counsel's performance or ability to perform in a competent manner. ${ }^{308}$ To promote the influx of such information, the $\mathrm{ABA}$ recommends that the monitoring entity establish and publicize "a regularized procedure for investigating and resolving complaints of inadequate representation. ${ }^{" 309}$ Naturally, the monitoring entity must follow up on these complaints and determine whether a potential problem actually exists and whether it ought to intervene in some fashion. ${ }^{310}$

307. McConville, supra note 13, at 110 (arguing that monitoring, along with competency standards, "will improve effectiveness and reduce (though not eliminate) the likelihood that capital defendants will suffer the burden of incompetent counsel").

308. See 2003 ABA Guidelines, supra note 2, at Guideline 7.1, at 973 (explaining that monitoring entity "should investigate and maintain records regarding any complaints made against assigned counsel by judges, clients and other attorneys"); $i d$. at 974 (noting that "many people (e.g., family members of the client, witnesses whom the attorney has interviewed or not interviewed) may be in a position to provide important information").

309. Id. at Guideline 7.1, at 974.

310. See Schwarzer, supra note 40, at 652 (arguing that "[i]f at any time during the proceeding the defendant makes a seemingly substantial complaint about the adequacy of counsel, whether appointed or retained, the judge should conduct an inquiry and make findings on whether bona fide grounds exist for a change of counsel").

Refusing to investigate complaints and monitor counsel's performance invites not only incompetent performance, but also delay, as demonstrated by the case of Ricky Kerr, a capital inmate in Texas. See Texas Defender Service, supra note 5, at 25-28 (criticizing the Texas court's failure to investigate Kerr's complaints about counsel). On July 22, 1997, Kerr's original postconviction counsel filed a postconviction 
But, as the ABA notes, monitoring must "go considerablybeyond" simply investigating complaints made by the defendant or others. ${ }^{311}$ The monitoring entity must actively search for, and solicit, the information it needs to assess the adequacy of counsel's performance. For example, as discussed above, the monitoring entity must check to determine whether counsel has filed the petition in a timely manner. It must also review the petition itself for obvious signs of problems, such as failure to raise known claims, failure to raise proper claims, and failure to raise any claims. Most of the monitoring entity's efforts, however, will be spent gathering information from counsel regarding counsel's level of preparation - specifically counsel's efforts in conducting an adequate investigation. Thus, the task here is to determine an effective way of obtaining that information.

There are two basic information-gathering methods-checklists and conferences - both of which have been discussed by numerous commentators in the context of monitoring the performance of trial counsel. ${ }^{312}$ The state and federal governments are free to adopt either procedure, or even to design a different information gathering procedure, provided the procedure actually targets the right information. A procedure that gathers useless, or little useful, information will not adequately protect the monitoring requirement, or the right to effective assistance of capital postconviction counsel, and thus will not satisfy the meaningfulness requirement.

petition that "raised no constitutional or jurisdictional claims concerning the fundamental fairness of the underlying trial or the accuracy of the verdict." Ex parte Kerr, 64 S.W.3d 414, 415-16 (Tex. Crim. App. 2002). In other words, the petition failed to "attack applicant's capital murder conviction or death sentence." Id. at 416. In a letter dated August 20, 1997, Kerr brought his counsel's deficiencies to the attention of the Texas Court of Criminal Appeals, but to no avail. Id. In the face of this complaint, as well as the obviously deficient petition, the Texas Court of Criminal Appeals nevertheless denied relief. Id. Five years later, after the federal district court "castigated the [state court's] behavior in ... appointing a plainly incompetent attorney with a serious health problem to represent Kerr," Texas Defender Service, supra note 5, at 26 (citing Kerr v. Johnson, No. SA-98-CA-151-OG, slip op., at 1, 20 (W.D. Tex. Feb. 24, 1999)), the Texas Court of Criminal Appeals finally allowed Kerr to file another petition, ruling that Kerr had "not yet had [a] full and fair opportunity" to present his claims on postconviction review. Ex parte Kerr, S.W.3d at 419. Of course, had the Texas courts actually monitored counsel's performance, or even listened to Kerr's complaints, they could have avoided the district court's reprobation and provided this "full and fair opportunity" for review much sooner. As of the date of this writing, Ricky Kerr remains on death row in Texas. For a detailed discussion of the Kerr case, see Texas Defender Service, supra note 5, at 25-28.

311. 2003 ABA Guidelines, supra note 2, at Guideline 7.1, at 973.

312. See, e.g., Bazelon, supra note 131, at 831 (discussing the use of pretrial "worksheets" as a method of monitoring trial counsel's level of preparation); Klein, supra note 40, at 580-84 (discussing the use of conferences and "worksheets" as methods of monitoring trial counsel's level of preparation); Levine, supra note 40, at 1431-35 (discussing the use of "checklists" and conferences to monitor trial counsel's level of preparation); Tague, supra note 40, at 162-64 (same). 
While both checklists and conferences could be designed to elicit sufficient relevant information regarding counsel's preparation, checklists represent the better alternative. To begin, checklists are better suited for the postconviction environment than are conferences. Unlike the trial context, where conferences occur as a matter of practice, ${ }^{313}$ conferences are not a routine part of the postconviction process. ${ }^{314}$ Thus, there is no efficiency gained by using conferences as an information-gathering mechanism. This perhaps explains why California, which has the largest number of inmates on death row, ${ }^{315}$ has a "longstanding court practice" of requiring capital postconviction counsel to submit checklists to the postconviction court. ${ }^{316}$

Moreover, checklists are more efficient than conferences in terms of the actual time spent monitoring counsel's performance. ${ }^{317}$ With checklists, all the monitoring entity need do is review the answers provided by counsel and determine whether intervention by the monitoring entity is warranted. Conferences, on the other hand, require the monitoring entity to physically attend a meeting with counsel and to personally extract and record all relevant information regarding counsel's performance - a much more time-consuming endeavor than simply reviewing a checklist.

Finally, checklists do not present the same risk of interfering with the attorney-client privilege as do conferences. As Professor Levine explained, conferences naturally "allow more probing [than checklists and thus] would ... require ... self-restraint [by the monitoring entity]. Lawyers would

313. E.g., Levine, supra note 40, at 1435 (noting that "[p]retrial conferences ... are often permitted or required by court rule in both civil and criminal cases"). This, perhaps, explains why commentators have recommended using pretrial conferences to monitor trial counsel. See Schwarzer, supra note 40, at 665; Levine, supra note 40, at 1433.

314. Conferences are useful in the trial context because the parties can get together with the court to discuss settlement, as well as issues relating to the upcoming trial, such as "motions and evidence." Levine, supra note 40, at 1435 . There is no similar need for a pre-petition conference with the court.

315. See Death Penalty Information Center, Death Row Inmates By State, at www. deathpenaltyinfo.org/article.php?scid=9\&did=188\#state (last visited Nov. 29, 2004) (noting that California has 635 inmates on death row).

316. Press Release, Judicial Council of California, supra note 34, at Addendum I.B, available at http://www.courtinfo.ca.gov/newsreleases/NR54-01.htm. In 2001, California codified this "longstanding court practice." Id. ("In accordance with longstanding court practice, . . . until appointed habeas corpus/executive clemency counsel files a concurrent capital-related state habeas corpus petition, a current confidential status report must be submitted every 60 days."). Although California does not appear to expressly require the court to monitor counsel's performance, the requirement for a confidential status report strongly suggests that the courts are at least authorized, if not encouraged, to monitor counsel's performance.

317. E.g., Klein, supra note 40, at 582 (noting that "[a]n advantage of the worksheet approach is that it involves less court time"); Tague, supra note 40 , at 163 (noting that check lists pose "fewer problems than ... conferences," and that conferences "consume too much time and money"). 
rightly fear violating the attorney-client privilege." ${ }^{318}$ With checklists, no such self-restraint (or fear of breach) is necessary, as the checklists can deliberately avoid questions that might lead to a breach of confidentiality.

The process for using checklists as an information-gathering method is straightforward: the monitoring entity would simply create the checklist and submit it to counsel to complete and return. The monitoring entity should require counsel to update the checklist on a regular basis ${ }^{319}$ and should be authorized to request supplemental information from counsel whenever necessary. ${ }^{320}$ Supplemental and updated checklists allow the monitoring entity to probe counsel's performance, as well as view counsel's progress at various stages in the investigatory process. The monitoring entity can detect at least some problems early in the process, and can then monitor counsel's progress to ensure that counsel has taken steps to rectify the problem. Critically, all of this can be done before the petition is actually filed.

In terms of content, the checklist (like any information-gathering method) must target counsel's compliance with her duty to investigate the case. ${ }^{321}$ It must seek to gather enough information regarding counsel's preparation to allow the monitoring entity to detect all easily-identifiable outward signs of poor performance. And, the best way to do that is to use the checklist as a questionnaire, asking counsel a series of specific questions regarding counsel's compliance with her duty to investigate the case. ${ }^{322}$ Such questions

318. Levine, supra note 40, at 1433.

319. California requires counsel to file an updated checklist every 60 days. Press Release, Judicial Council of California, supra note 34, at Addendum I.B, available at http://www.courtinfo.ca.gov/ newsreleases/NR54-01.htm; see also Tague, supra note 40, at 164-65 (suggesting more than one checklist or conference).

320. California authorizes the court to request supplemental information. Press Release, Judicial Council of California, supra note 34, at Addendum I.C, available at http://www.courtinfo.ca.gov/ newsreleases/NR54-01.htm ("[A]ppointed counsel, as appropriate, may be requested to submit a supplemental confidential status report.").

321. See Schwarzer, supra note 40, at 654-55 (recommending a pretrial conference in which the trial judge "get[s] a sense of the extent of counsel's preparation, familiarity with criminal trial procedure, and general competence to handle the defense").

322. See Tague, supra note 40, at 164 (recommending questionnaire format when monitoring trial counsel's preparation). Professor Tague's sample questions do more than ask whether counsel has performed specific steps in the preparation process; they ask counsel to explain why she has or has not taken these steps. See id. at $164 \mathrm{n} .285$ (asking counsel to explain reasons for not investigating the crime scene, interviewing witnesses or filing certain motions). Such questions, however, could reveal legal strategy and, thus, could violate attorney-client confidentiality. Accordingly, they should not appear on the postconviction monitoring checklist.

Professor Tague recognized this problem, and suggested that the checklist be completed by counsel and given to the defendant rather than the court. Id. at 164 . If the defendant had concerns about the substance of the checklist (and, hence, counsel's performance), then he "could object to the judge. By 
should include the basic steps counsel has taken in the investigation process ${ }^{323}$ (as outlined by the ABA), ${ }^{324}$ the number of hours counsel has worked on the case, the number and type of discovery requests submitted by counsel, and the identity of all claims raised in earlier (or separate) proceedings that must be raised and preserved during postconviction review. Answers to these questions can help the monitoring entity spot signs of potentially incompetent performance.

California formats its checklist (what it calls a "confidential status report" $)^{325}$ a little differently. Rather than asking a series of specific questions about counsel's performance, it asks counsel to discuss the following four issues:

1. Current case status, including a good faith estimate of the percentage of work accomplished to date with regard to each pending uncompleted task.

2. Progress during the last 60 days.

3. Problems and reasons for any delay.

4. Future plans, including a good faith estimate of the amount of time it will take for the remaining work to be done as to each pending uncompleted task, and a proposed target date for completion of each such task. ${ }^{326}$

These issues correctly focus on counsel's efforts to prepare the case, and discussion of these issues, if fulsome, undoubtedly will help the monitoring

objecting, he would waive the attorney-client privilege. If he did not object, the attorney-client privilege problem would disappear, because neither the judge nor prosecutor would see the form." Id. This procedure would be inappropriate in the postconviction context, however, because the meaningfulness requirement demands that the monitoring entity monitor every counsel, and, to effectively do so, it must have access to the checklist. For a critique of Professor Tague's approach in the trial context, see Levine, supra note 40 , at $1432-33$.

323. Cf. Schwarzer, supra note 40 , at $654-55$ (discussing the trial judge's duty, during pretrial conference, to inquire into counsel's basic investigatory efforts). The checklist would not simply ask counsel whether she believes she has completed the basic steps in the investigatory process. Instead, it would ask specific questions about what counsel has done to investigate the case, such as whether and when counsel has interviewed the client, who counsel has interviewed as potential witnesses, who counsel plans to interview, and whether counsel has investigated her client's social, family, and educational history. These do not represent an exhaustive list of questions, but simply demonstrate the level of specificity the questions must take.

324. In the context of monitoring trial counsel, observers have recommended using ABA standards in fashioning the topics probed by the monitoring entity. See Klein, supra note 40, at 582 (noting that pretrial "worksheet could be based on the ABA's Standards for the Administration of Criminal Justice, Chapter Four: The Defense Function"); Schwarzer, supra note 40, at 654 (noting that ABA standards are a good "starting point" for determining whether counsel is performing competently); Tague, supra note 40, at $164 \mathrm{n} .285$ (recommending a checklist that "follow[s] the ABA guidelines").

325. Press Release, Judicial Council of California, supra note 34, at Addendum I.B, available at http://www.courtinfo.ca.gov/newsreleases/NR54-01.htm.

326. $I d$. 
entity measure counsel's level of preparation. Equally important, the issues are phrased in such a way as to force counsel to engage in a critical evaluation of her own progress, honestly evaluating the amount of work that has been accomplished, explaining any reasons for delay, and providing a realistic assessment of the time it should take to complete each remaining task. ${ }^{327}$ Such a self-evaluation can help counsel see (and correct) problems with her own performance. It also keeps counsel focused on what is necessary to complete a thorough investigation, (hopefully) making it more likely that counsel will actually complete the required tasks.

California's procedure, while a step in the right direction, unfortunately does not go far enough to ensure that counsel-in each case-will provide enough information about her preparation to allow the monitoring entity to adequately evaluate her performance. And this is precisely because the California status report does not pose specific questions about counsel's investigatory efforts. While it is certainly possible that counsel will, in the course of discussing the four issues identified above, reveal all of the relevant information about her performance, it is equally possible that she will not. Counsel could, for example, answer issue 2 (progress in the last 60 days) either by describing the steps she has taken to investigate for mitigating evidence or by simply stating that she has completed (or about to complete) her mitigation investigation. The former answer would help the monitoring entity assess her preparation, while the latter would not. Thus, without questions specifically targeting counsel's investigatory efforts, California's procedure is insufficient to adequately protect the monitoring requirement and, in turn, the right to effective assistance of capital postconviction counsel.

Checklists have been criticized for "reveal[ing] only gross cases of poor investigation," rather than "instances of inadequacy, as when a lawyer was blinded by his own cynicism, his relationship with a client, or by a dogmatic approach to a factual or legal issue." 328 But this criticism does not undermine the use of pre-petition checklists in the postconviction context, for, as described above, monitoring is supposed to reveal easily identifiable problems with counsel's performance and not the more subtle errors detectable only by a substantive examination of the case. Checklists have also been criticized for imposing a burden on counsel "regardless of whether ineffectiveness is a

327. See supra note 146 and accompanying text.

328. Bazelon, supra note 131, at 831; see also Levine, supra note 40, at 1431-32 ("The trial judge will be forced to review the worksheet in a vacuum, with no detailed knowledge of the case and no immediate opportunity to ask questions."). 
genuine issue." 329 This burden is necessary, however, in order to protect the right to effective assistance of counsel. The monitoring entity cannot determine ahead of time who is and who is not performing well, for, as the ABA has warned, "[i]t cannot always be safely assumed that counsel who has been determined to be qualified based on past performance will represent current or future clients satisfactorily." 330

\section{Appropriate Remedies}

The last, but certainly not the least, question is how to respond to, and remedy, problems discovered during the monitoring process. In instances where counsel's performance is seriously deficient, one way to respond, of course, is to remove counsel from the roster of eligible attorneys, thereby ensuring that she will not be appointed in future capital postconviction cases. $^{331}$ This undoubtedly is an important remedy, as it protects future capital postconviction petitioners from bearing the burden of the attorney's incompetence. ${ }^{332}$ But it is an insufficient remedy, as it does nothing to protect the capital petitioner in the case under review from bearing the burden of the attorney's incompetence. To satisfy the meaningfulness requirement, the government must adequately protect each capital inmate's right to effective assistance of postconviction counsel. Accordingly, the government must do more than simply have counsel removed from the list of certified attorneys; it must seek to prevent counsel's deficiencies from impacting the capital inmate's ability to have her claims reviewed on the merits.

Apparently recognizing this point, the ABA recently amended its Guidelines to direct the monitoring entity to "take appropriate action to protect the interests of the attorney's current and potential clients." ${ }^{333}$ Unfortunately,

329. Bazelon, supra note 131, at 831 (noting that the use of a checklist "would impose a burden, albeit a minimal one, on lawyers in every case, regardless of whether ineffectiveness is a genuine issue").

330. 2003 ABA Guidelines, supra note 2, at Guideline 7.1, at 974 n.127.

331. See id. at Guideline 7.1, at 970 ("Where there is evidence that an attorney has failed to provide high quality legal representation, the attorney should not receive additional appointments and should be removed from the roster.").

332. The risk that incompetent counsel will receive future appointments if she remains on the list is real. As the Texas Defender found in its recent study, "local trial judges [in Texas] continue to appoint the same lawyers - many of whom are known to be inexperienced, untrained or infamous for their poor work in past cases - who then file perfunctory habeas petitions." Texas Defender Service, supra note 5, at 50; see $i d$. at xiii (revealing that many attorneys who were disciplined by the state bar "remain eligible for additional appointments").

333. 2003 ABA Guidelines, supra note 2, at Guideline 7.1, at 970 (emphasis added). The mandate to protect the current client by taking "appropriate action" appears for the first time in the 2003 version of 
however, the ABA neglected to specify what it meant by "appropriate action." This section seeks to give content to that phrase by examining the scope of remedial action required by the meaningfulness requirement.

In terms of protecting the capital inmate in the particular case in which counsel is being monitored, there are three basic ways to respond to problems detected by the monitoring entity: (1) an oral or written notification to counsel by the monitoring entity identifying the nature of the problem and the steps counsel should take to rectify the problem, followed by additional monitoring; (2) an extension of time for filing the postconviction petition; and (3) the removal and substitution of counsel. Which remedy-or combination of remedies - the monitoring entity should use (or seek, if the entity is an independent agency) will depend not only upon the nature and extent of the problems the monitoring entity has identified, but also upon the weight of the government's interests in avoiding delay and achieving finality. ${ }^{334}$ As a general rule, this means that the remedy (or combination of remedies) must not intrude on the government's interests any more than is necessary to help prevent the problem from interfering with the capital inmate's ability to have her claims addressed on the merits. ${ }^{335}$ So, even if removal and substitution of counsel - a fairly extreme remedy ${ }^{336}$ — would effectively cure a problem with

the ABA GuIDELINES, and would seem to contemplate not only removal from the individual case, but also other, perhaps less drastic, remedies as well. See id. at 973-74 (noting that the monitoring entity "should intervene" if it has evidence that counsel is not "providing high quality legal representation"). The 1989 version of the GUIDELINES permitted removal of counsel from individual cases in instances where the capital inmate did not object, but the main remedy appeared to be removal from the roster. See 1989 ABA GUIDELINES, supra note 35, at Guideline 7.1, at 41.

334. A similar balancing test is used to determine whether to grant a criminal defendant's request for removal and substitution of counsel, and whether to remove criminal defense counsel over the objections of a criminal defendant. See, e.g., United States v. Welty, 674 F.2d 185, 187 (3d Cir. 1982) (holding that when considering whether to grant defendant's request for removal and substitution of counsel, "the court must decide if the reasons for the defendant's request ... constitute good cause and are thus sufficiently substantial to justify a continuance of the trial in order to allow new counsel to be obtained"); Smith v. Superior Court, 440 P.2d 65, 72-73 (Cal. 1968) (holding that when considering whether to remove counsel over the objection of a defendant, courts must protect the defend ant's right to effective assistance of counsel without "infring[ing] upon the defendant's right to counsel of his choice [or] compromis[ing] the independence of the bar").

335. See Schwarzer, supra note 40, at 559-60 (arguing that trial court's intervention should become more aggressive as the seriousness of the problem increases); $i d$. at 650 (explaining that a trial judge's "function is to remedy observed deficiencies before it is too late, resorting always to the least intrusive measure adequate to the need") (emphasis added).

336. See, e.g., Smith, 440 P.2d at $72-73$ (discussing the nature of the removal remedy); State v. Huskey, 82 S.W.3d 297, 309 (Tenn. Crim. App. 2002) (noting that "removal of counsel should only occur when no other options exist"); Klein, supra note 40, at 571 (observing that removal remedy is fairly extreme from the judge's standpoint, because "[a]ny change of counsel causes delay and keeps the case on the 
counsel's performance, it would not be required if the problem can be solved equally well in another, less intrusive, fashion. It also means that, in some instances, the capital inmate will have to accept a less-than-perfect remedy in order to prevent undue injury to the government's interests. The meaningfulness requirement, in other words, does not require an endless stream of remedies in response to problems detected in the monitoring process.

Rather than simply exploring the viability of each of the above remedies in isolation, the discussion below examines how the monitoring entity ought to respond if it finds that counsel is unable to perform, or that counsel has failed to comply with the three basic duties required of all capital postconviction counsel.

\section{Inability To Perform Competently}

If the monitoring entity discovers evidence demonstrating that counsel cannot perform effectively, for whatever reason, ${ }^{337}$ then counsel should be removed from representing the capital inmate and replaced by competent counsel. ${ }^{338}$ Inevitably, removal causes some delay in the postconviction process, because the newly appointed counsel cannot just pick up where prior counsel left off. Instead, she essentially must start from scratch, familiarizing herself with the case and determining how best to represent the capital inmate. Nevertheless, removal — and the attendant delay — is necessary in order to protect the capital inmate's ability to present her claims for review. If counsel cannot perform competently, then allowing her to continue representing the capital petitioner would effectively strip the petitioner of her right to counsel. ${ }^{339}$

judge's calendar for a longer period of time"); Tague, supra note 40, at $162 \mathrm{n} .282$ (noting that "[j]udges are reluctant to remove an appointed attorney from a case ... without clear standards governing how attorneys should represent their clients").

337. In addition to "physical or mental impairment[s]," which are the main examples of inability to perform, see supra notes 237-39 and accompanying text, counsel's workload might also render her incapable of performing adequately. 2003 ABA Guidelines, supra note 2, at Guideline 7.1, at 974 (noting that counsel's workload is a relevant factor in assessing ability to perform competently).

338. See, e.g., Cal. Rules of Court Policy Statement 2 (Deering 2004) (permitting withdrawal of counsel "when appointed counsel becomes mentally or physically incapacitated"); Smith, 440 P.2d at 72 (noting that "[a]ll will agree that if the defendant's attorney exhibits objective evidence of [p]hysical incapacity to proceed with a meaningful defense of his client, such as illness, intoxication, or a nervous breakdown," trial courts "should inquire into the matter ..., and if necessary relieve the affected counsel and order a substitution"); Tennessee v. Huskey, 82 S.W.3d 297, 307 (Tenn. Crim. App. 2002) (same).

339. See In re Sanders, 981 P.2d 1038, 1045-46 (Cal. 1999) (noting that when counsel does 
The other remedies are no less intrusive on the government's interests. In general, simply identifying counsel's problem will not improve her ability to represent her client, nor will an extension of time. Thus, invoking these remedies in an attempt to solve the problem normally will not eliminate the need for removal, and, thus, will only serve to aggravate the government's interest in avoiding delay. Moreover, even if we knew for certain that the circumstances causing counsel's inability to perform - such as a crushing workload - would disappear within a certain period of time, immediate removal still represents a better remedy than an extension of time. With an extension of time, the original attorney naturally cannot perform any meaningful work on the case while she is incompetent or overburdened, so the time spent waiting for circumstances to change - that is, for the original attorney to become competent or less burdened-would be wasted. With removal, on the other hand, the newly appointed attorney can begin working the case immediately, thereby minimizing any delay. Indeed, she might well make significant headway on the case in the time it would take the original lawyer to become fit to represent the capital inmate. In short, in instances when counsel is unable to perform competently, removal and substitution of counsel is the best remedy for both the capital inmate and the government. ${ }^{340}$

\section{Failure To Conduct Adequate Investigation}

The remedy will not always be quite so drastic in instances where the monitoring entity discovers that counsel has failed, in some manner or another, to conduct an adequate investigation. Assuming the deficiency can be corrected fairly easily, the first line of defense is for the monitoring entity to identify the deficiency (either orally or in writing) and explain what counsel ought to be doing to rectify the problem. ${ }^{341}$ If the deficiency was detected

\footnotetext{
"absolutely nothing to commence a habeas investigation" or "ceases representation before he or she should have done so," counsel effectively "places a habeas corpus petitioner in the same position as he or she would have been in had he or she been unrepresented").

340. Removal would be appropriate even if the capital petitioner objects, for although removal is a severe remedy, it is necessary to protect the right to counsel. In the trial context, for example, courts remove counsel over the objection of the criminal defendant if doing so is necessary to protect the right to effective assistance. See, e.g., Smith, 440 P.2d at 72-73 (stating the rule). This is true even though the defendant has a "right to counsel of his choice." Id. at 72. See also supra note 220 and accompanying text.

341. Schwarzer, supra note 40, at 659 ("When inquiry discloses that counsel appears to be lacking in diligence or skill, but the shortcomings appear to be remediable, the court should consider giving appropriate suggestions, advice or directions to prevent a default.") (emphasis added). Because under his proposal the judge performs the monitoring function, Judge Schwarzer recommended that such discussions occur "on the record and in the presence of opposing counsel." Id. In the postconviction context, if the
} 
fairly late in the investigatory process, then the monitoring entity's advice should include a suggestion that counsel seek an extension of time in which to file the petition. ${ }^{342}$ Within a reasonably short period of time after notifying counsel of the problem, the monitoring entity should monitor counsel's progress with a follow-up checklist. Hopefully, counsel will rectify the deficiency in short order. If so, then no further intervention would be warranted on this particular issue.

If, on the other hand, counsel has failed to rectify the deficiency, or if the deficiency is egregious, ${ }^{343}$ then a more aggressive response would be warranted. ${ }^{344}$ At this point, (another) notification to counsel identifying the problem, or even an (additional) extension of time, would undermine both the capital inmate's interest in competent representation and the government's interest in keeping the postconviction process moving toward a timely conclusion, as it is unlikely that counsel will suddenly "shape up" and begin remedying identified deficiencies. In these circumstances, the postconviction court ought to remove counsel and appoint a substitute counsel. Again, removal admittedly will aggravate the government's interests in avoiding delay, as new counsel would have to begin investigating the case from scratch. But, in these particular circumstances, the delay is necessary to vindicate the capital inmate's right to effective assistance. As explained earlier, a thorough investigation is a crucial ingredient to a successful capital postconviction petition, ${ }^{345}$ for, without it, counsel would not know which claims to raise in the postconviction petition. And, in the words of the Texas Defender Service, "the barometer of the quality of representation is whether or not appropriate

judge performs the monitoring function and chooses to notify counsel of the problem orally, then it would probably be best to include opposing counsel in the discussion. It would not seem necessary, however, to put the discussion on the record.

342. Of course, if the court is the monitoring entity, it need not give this advice. Instead, it should consider granting such an extension on its own motion.

343. A few examples immediately come to mind, not the least of which is the case of Johnny Joe Martinez, whose counsel filed a five-page petition and worked only 50 hours on the case. See supra notes 276-85 and accompanying text. Other examples would include a complete failure to investigate, and an identifiable failure to conduct most of the basic steps in the investigation. In all of these situations, it is unrealistic to expect counsel to fix the problems and move ahead with competent representation. Instead, counsel's deficiencies represent a strong signal of continued incompetence, which naturally interferes with the capital inmate's ability to obtain review of her claims on the merits.

344. See Schwarzer, supra note 40, at 659 (noting that if trial "counsel's inadequacy appears to be so serious that it creates a risk of ineffective representation, the court should advise the client of that fact and of the right to change counsel").

345. E.g., Texas Defender Service, supra note 5, at 12; 2003 ABA Guidelines, supra note 2, at Guideline 10.15.1, at 1080, 1085-86. 
claims are filed in the habeas petition." ${ }^{\$ 46}$ Quite simply, an egregious or continued failure to conduct such an investigation so seriously threatens the capital inmate's ability to have her claims decided on the merits as to justify the intrusion on the government's interests. ${ }^{347}$

Naturally, federalism concerns are going to put a limit on how much delay the state must endure as a result of the monitoring process; hence, removal probably would not be warranted in the event new counsel shows signs of performing an inadequate investigation. At this stage, it would be sufficient for the monitoring entity to simply remind counsel of her duties, as well as the importance of conducting an adequate investigation, and then to follow up with additional monitoring. While this response might not prevent an inadequate investigation (that is, one that fails to uncover a potentially meritorious claim), it is the best the monitoring entity can do, given the competing interests at stake. And, again, while the monitoring requirement is designed to protect the right to effective assistance, it cannot - and does not-guarantee effective assistance.

\section{Failure To Raise Known Claims}

Unlike most investigative failures, counsel's actual failure to raise known claims - that is, those claims that were raised in earlier or separate proceedings and that must be preserved on postconviction review-cannot be detected until the petition has been filed. ${ }^{348}$ At this point in the process, only

346. Texas Defender Service, supra note 5, at $\mathrm{x}$.

347. In addition to removal from the case, counsel should also be removed from the list of eligible attorneys. The postconviction court might also consider imposing monetary sanctions on counsel and, depending the nature of the deficiency, perhaps referring the matter to the state bar for possible disciplinary proceedings. See, e.g., Burke v. Nevada, 887 P.2d 267, 269 (Nev. 1994) (removing criminal trial counsel, imposing monetary sanctions, and "refer[ring] . . . matter to the State Bar of Nevada for further investigation concerning possible violations of the Supreme Court Rules governing professional conduct"); Cudzey v. Nevada, 747 P.2d 233,236 (Nev. 1987)(removing criminal trial counsel and imposing monetary sanctions); see also Levine, supra note 40, at 1441 (discussing how sanctions or referral to disciplinary authority could help improve attorney conduct). While these tactics will not prevent harm from befalling the capital inmate in the particular case, they should discourage counsel from engaging in similar conduct in the future, thereby reducing the chance that counsel will injure future clients, both capital and noncapital.

348. As discussed earlier, the monitoring entity can fairly easily check to make sure that counsel has properly preserved all claims that were raised in earlier or separate proceedings and that must be raised again on postconviction review. See supra notes 303-05 and accompanying text. The monitoring entity cannot, however, ensure that all new claims - that is, those that should be discovered during the investigation-have been raised. See supra note 306 and accompanying text. To prevent loss of these claims, all the meaningfulness requirement requires is for the monitoring entity to monitor the adequacy 
an extension of time to file an amended petition would adequately redress the harm caused by counsel's failure. Removal and substitution should be unnecessary, since the monitoring entity will have identified the missing claims. All counsel need do is include them in an amended petition and re-file it within the relevant time period. ${ }^{349}$

It is true that extensions of time delay the conclusion of postconviction proceedings, thus aggravating the government's interests in bringing the postconviction proceedings to a timely conclusion. Nevertheless, this delay-which likely will be significantly less than that caused by removal and substitution of counsel-is necessary in order to ensure that the capital inmate's claims are heard and decided on the merits, which of course is the very goal of providing effective counsel in the first place. ${ }^{350}$ Indeed, both California and Texas - which have the most number of inmates on death row in the nation ${ }^{351}$ - permit extensions of time in which to file a postconviction petition, ${ }^{352}$ suggesting that extensions do not always unduly aggravate the government's interests in avoiding delay. ${ }^{353}$ In other words, sometimes the

of counsel's investigation. Id.

349. Of course, if counsel has shown other signs of actual or potential incompetence sufficient to cause the monitoring entity to doubt counsel's ability to competently amend the complaint, removal would be warranted.

350. Cf. Meltzer, supra note 131, at 1187 (arguing that broader rules excusing procedural default "can ... be seen as a kind of subconstitutional protection against ineffective assistance of counsel, one which limits the difficulties of post default litigation").

351. Death Penalty Information Center, Death Row Inmates by State, supra note 315.

352. Tex. Code Crim. Proc. AnN. art. 11.071 § 4A (Vernon Supp. 2004-2005) (allowing the court to "establish a new filing date" for the postconviction petition, provided counsel shows "cause" for failure to file a timely petition); Cal. Rules of Court Policy Statement 3 (Deering 2004) (allowing the court to excuse "substantial delay" in filing postconviction petition if petitioner shows "good cause").

Professor Andrew Hammel recently conducted a thorough examination of whether, and how, states "guarantee[] competent performance by appointed state post-conviction counsel." Hammel, supra note 9, at 353. Professor Hammel reveals several instances in which states have remedied problems caused by ineffective postconviction counsel. Id. at 353-64. These states, Hammel explains, "temper their enforcement of procedural bars in habeas proceedings to avoid unjustly harsh outcomes or ensure prisoners do not suffer by procedural problems caused ultimately by the state's failure to appoint competent counsel." Id. at 364 . In other words, the need for fairness sometimes outweighs the government's interests in avoiding delay. See id. at 371 (arguing that states that refuse to provide such remedies believe the remedies "pos[e] an unacceptable threat of delay in carrying out the death penalty").

353. To be fair, California appears to interpret its "good cause" standard fairly narrowly. For example, the California Supreme Court held that abandonment by counsel constituted good cause to excuse a failure to file a timely petition. In re Sanders, 981 P.2d 1038, 1045 (Cal. 1999). It is possible that failure to raise known claims, which in some cases would seem less egregious than abandonment, might not be considered "good cause" under California's standard. But, the point of citing the California statute is not to demonstrate that California would excuse such behavior; it is to show that, even from the government's point of view, the need to reduce delay does not always outweigh concerns for fairness. And, this Article 
concern for the fair and reliable administration of justice outweighs the concerns regarding delay and lack of finality. ${ }^{354}$ Counsel's failure to raise all known claims in the postconviction petition represents one of those times.

One might argue that an extension of time is unworkable as counsel might easily miss the new deadline, necessitating another extension and further delaying the postconviction process. But this problem can be prevented-at least in most cases - by having the monitoring entity keep close tabs ${ }^{355}$ on counsel's progress with the amendment and filing process. Similarly, the postconviction court could impose monetary sanctions on counsel when it grants the extension, and inform counsel that further sanctions-including referral to the relevant licensing authority for disciplinary proceedings ${ }^{356}$ - will follow if counsel fails to file a timely, and appropriately amended, petition. Such sanctions should be enough to encourage counsel to do the minimal work necessary to amend and re-file the petition. But, if they are not, and counsel nevertheless fails to file a timely amended petition, no further extensions would be warranted. The meaningfulness requirement demands the government provide adequate protection for the right to effective assistance, not perfect protection. At this point in the process - and after reasonable effort to prevent error- the capital postconviction petitioner would have to bear the burden of counsel's errors.

One might also argue that granting even one extension of time is a bad idea, as it creates an incentive for counsel to deliberately engage in conduct that will catch the attention of the monitoring entity, thereby delaying the case. ${ }^{357}$ For example, in an effort to obtain more time to investigate the case,

argues that when capital postconviction counsel fails to raise known claims in a postconviction petition, concerns for fairness outweigh the government's desire to avoid delay.

354. As the California Supreme Court stated:

A tension is . . created between society's desire for finality of its criminal judgments and its insistence the person being punished is actually guilty of the crimes of which he or she was convicted. One way we attempt to resolve this tension is to require collateral challenges to be filed promptly, but to excuse delay on a showing of good cause.

In re Sanders, 981 P.2d at 1042. See also Hammel, supra note 9, at 353-64 (discussing Sanders and other cases).

355. The monitoring entity could do this, for example, by periodically contacting counsel, orally or in writing, to inquire about her progress. Alternatively, the monitoring entity could require counsel to provide frequent written or oral updates on her progress.

356. The court could also hold counsel in contempt and reduce or eliminate her fees. See Ex parte Kerr, 64 S.W.3d 414, 421 (Tex. Crim. App. 2002) (discussing the court's power to "hold [an] attorney accountable" for misconduct); $c f$. Schwarzer, supra note 40, at 659-60 n.121 (suggesting that a court might adjust attorney's fees in instances when removal is also necessary).

357. Cf. Meltzer, supra note 131, at 1196-1209 (noting that the excusal of procedural defaults might encourage counsel to deliberately "withhold a federal claim in state court, in the hopes of having the default 
or perhaps simply to delay imposition of her client's death sentence, ${ }^{358}$ counsel might deliberately fail to raise known claims in the petition, knowing that she will obtain an extension of time. In this particular situation, however, the incentive cannot be that great, as the extension of time necessarily should be quite short, as it should take little time to amend the petition. Moreover, even if the incentive is great, the postconviction court might be able to deter such conduct by imposing monetary sanctions on counsel at the same time that it grants the extension. ${ }^{359}$ But, even if such conduct cannot be deterred, the risk that some lawyers might engage in dilatory tactics in order to obtain a onetime delay in the process is one we must endure in order to adequately protect the right to effective assistance of counsel. The meaningfulness requirement allows no less.

\section{Failure To File Timely Petition}

Like failure to raise known claims, the monitoring entity will be unable to detect a complete failure to file a petition until the time for filing has actually passed. At this point, there are two basic options: extend the time for filing the petition and keep counsel, or extend the time for filing the petition and remove counsel. ${ }^{360}$ Naturally, the circumstances of the individual case

excused later in the proceedings").

358. As the California Supreme Court explained, engaging in conduct to

delay[] the proceedings may be viewed by some attorneys representing defendants condemned to suffer the death penalty as a strategic or tactical decision, for unless the defendant has potentially meritorious legal claims to raise an attorney may believe that delaying final adjudication of legal claims is the only way realistically to serve the client's interests.

In re Sanders, 981 P.2d at 1049 n.9. The advent of filing deadlines has made the failure to file a petition quite risky, thereby reducing the incentive to engage in such conduct. $I d$. Indeed, since the establishment of deadlines in which to file petitions "habeas corpus petitions generally are filed in a timely fashion" in the California Supreme Court. Id.

359. See Levine, supra note 40, at 1441 (discussing how sanctions or referral to disciplinary authority could help improve attomey conduct). Such sanctions might even include reduction in the attorney's fees. Cf. Schwarzer, supra note 40, at 659-60 n. 121 ("If it becomes necessary to suggest or order the removal of an attorney, the judge should keep in mind the court's disciplinary authority over attorney's fees.").

If a court finds that counsel engaged in behavior designed to delay the proceeding, it could impose further sanctions, such as holding counsel in contempt, reducing or eliminating counsel's fees, and referring the matter to a disciplinary authority. See Ex parte Kerr, 64 S.W.3d at 421 (describing court's authority to "hold [an] attorney accountable" for misconduct).

360. Texas permits both options. See Tex. Code Crim. Proc. Ann. art. $11.071 \S 4$ A(b)(2)(Vernon Supp. 2004-2005) (stating a court may "permit the counsel to continue representation of the applicant and establish a new filing date for the application"); $i d$. $\$ 4 \mathrm{~A}(\mathrm{~b})(3)$ (noting the court may "appoint new counsel to represent the applicant and establish a new filing date for the application"). For a discussion criticizing the failure of the courts to forgive untimely petitions, see Bright, Elected Judges, supra note 171, at 
will dictate which of the two options is appropriate. For example, if counsel has shown no other signs of incompetence, then it is probably both wise and efficient to allow her to continue representing the capital inmate. If, on the other hand, counsel has shown other signs of incompetence, then it might be wise, although perhaps not more efficient, ${ }^{361}$ to remove her and appoint substitute counsel. In either instance, however, the postconviction court ought to impose monetary sanctions on counsel, not only to penalize counsel for missing the deadline, ${ }^{362}$ but also to deter similar (intentional or unintentional) failures in the future.

These remedies come late in the postconviction process and, as such, threaten to aggravate the government's interests in avoiding delay. This is especially true if removal and substitution is necessary. But, as explained above, delay is necessary in order to ensure that the capital inmate has an adequate opportunity to present her potentially meritorious claims to the postconviction court for review, for, without a petition, there is nothing for the court to consider. This does not mean, however, that counsel (and the capital inmate) should receive endless bites at the apple. If either the original or the new counsel fails to meet the newly established deadline, removal and further extensions of time would be inappropriate. Excusing the initial failure to file and providing the opportunity to cure the problem is sufficient protection for the capital inmate.

Like the extension of time remedy discussed in connection with counsel's failure to raise known claims, this extension remedy could create an incentive for counsel to deliberately miss the deadline. This incentive could be great, as the delay associated with this remedy likely will be longer than the delay associated with granting an extension to file a petition raising all known claims. Nevertheless, the postconviction court can penalize and (hopefully) deter such conduct by imposing monetary sanctions on counsel for such behavior. ${ }^{363}$ And, even if sanctions fail to squelch this incentive, the risk that counsel might engage in such delay tactics is one we must bear in order to protect the capital inmate's right to effective assistance.

$1822-24$.

361. Naturally, it will take more time for new counsel to get up to speed on the case. Recognizing this, Texas allows new counsel 270 days to file a petition, while it allows only 180 days if the original counsel continues to represent the capital inmate. Tex. Code Crim. Proc. AnN. art. $11.071 \S 4 \mathrm{~A}(\mathrm{~b})(2)-(3)$ (Vernon Supp. 2004-2005)

362. Again, the court might consider referral to a disciplinary authority, reducing or eliminating attorney's fees, imposition of a fine, or imposition of a contempt order. See supra notes 358, 359 and accompanying text.

363. See supra notes 356,359 and accompanying text. 


\section{CONCLUSion}

The government has no constitutional obligation to supply counsel to capital inmates who pursue postconviction review. But, if it chooses to provide such counsel (as many states and the federal government have done), then the Due Process Clause obligates the government to ensure that the right is meaningful. To be meaningful, the right to counsel must contain an effectiveness guarantee, which in the context of postconviction counsel means, at a minimum, that the government must monitor counsel's performance during the actual postconviction proceeding itself.

Just as the government has the obligation to make the voluntarilyprovided right to capital postconviction counsel meaningful, it must also ensure that the process for monitoring counsel's performance is itself meaningful. Thus, the government cannot simply put together any system of monitoring. Instead, it must structure the system for monitoring in a manner that adequately safeguards the right to effective assistance of capital postconviction counsel.

As shown in this Article, either the courts (provided they have the time and provided there is no evidence of routine, systemic disregard for the rights of capital inmates) or independent agencies can perform the monitoring function in a manner that satisfies the meaningfulness requirement. Regardless of which entity the government selects, however, the entity must utilize a preventive monitoring standard, seeking to uncover not just conduct that amounts to actual ineffective assistance, but also conduct that threatens the delivery of ineffective assistance. Such a standard is necessary to ensure that the monitoring requirement serves its purpose, which is, to the extent possible, to prevent problems from occurring in the first place. But, the standard need not seek to prevent all error, as this would unduly burden the government. Instead, the standard need only seek to uncover obviously identifiable signs that counsel is or might be performing incompetently. Essentially, this requires the monitoring entity to search for objective signs that counsel either is unable to perform competently or has failed to perform one of the basic duties required of all postconviction counsel. Finally, a meaningful monitoring system requires that, in the event the monitoring entity detects a problem, it undertake reasonable, though not endless, efforts to prevent that problem from interfering with the capital inmate's ability to present her claims to the postconviction court.

As is evident, the meaningfulness requirement does not demand a monitoring system designed to guarantee perfect performance in each and 
every case. It does, however, require reasonable efforts to detect and remedy objectively identifiable problems with counsel's performance - problems that extend beyond a complete failure to conduct an investigation or failure to file a timely petition. Indeed, the system of monitoring described above should allow the monitoring entity to detect and remedy a fairly wide range of problems with counsel's performance. Such monitoring, while an imperfect solution from the capital defendant's standpoint, appropriately balances the defendant's interests in receiving competent counsel with the government's interests in avoiding delay and achieving finality. And, in the end, capital inmates will be in a better position than they are now, as monitoring will increase the level of attorney competence, and thereby decrease the instances in which capital inmates must bear the burden of counsel error. 